\title{
Continuous Roll-to-Roll a-Si Photovoltaic Manufacturing Technology
}

\section{Annual Subcontract Report 1 April 1992 - 31 March 1993}

M. Izu

Energy Conversion Devices, Inc.

Troy, Michigan

NREL technical monitor: R. Mitchell

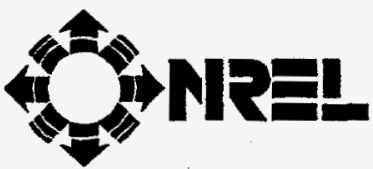

National Renewable Energy Laboratory 1617 Cole Boulevard Golden, Colorado 80401-3393

A national laboratory operated for the U.S. Department of Energy under contract No. DE-AC02-83CH10093

Prepared under Subcontract No. ZM-2-11040December 1993 


\section{NOTICE}

NOTICE: This report was prepared as an account of work sponsored by an agency of the United States government. Neither the United States government nor any agency thereof, nor any of their employees, makes any warranty, express or implied, or assumes any legal liability or responsibility for the accuracy. completeness, or usefulness of any information, apparatus, product, or process disclosed, or represents that its use would not infringe privately owned rights. Reference herein to any specific commercial product, process, or service by trade name, trademark, manufacturer, or othenwise does not necessarily constitute or imply its endorsement, recommendation, or favoring by the United States government or any agency thereof. The views and opinions of authors expressed herein do not necessarily state or reflect those of the United States government or any agency thereof.

Printed in the United States of America

Available from:

National Technical Information Service

U.S. Department of Commerce

5285 Port Royal Road

Springfield, VA 22161

Price: Microfiche AO1

Printed Copy A05

Codes are used for pricing all publications. The code is determined by the number of pages in the publication. Information pertaining to the pricing codes can be found in the current issue of the following publications which are generally available in most libraries: Energy Research Abstracts (ERA); Government Reports Announcements and Index (GRA and I); Scientific and Technical Abstract Reports (STAR); and publication NTIS-PR-360 available from NTIS at the above address. 


\section{DISCLAIMER}

Portions of this document may be illegible electronic image products. Images are produced from the best available original document. 


\section{Table of Contents}

291949394

OSTI

PAGE

Preface

1

List of Figures

$2-4$

List of Tables

4

Executive Summary

Objectives

5

Approaches

5

Major Accomplishments in Phase 1

$6-7$

Introduction

7

ECD'S a-Si Alloy PV Manufacturing Technologies

ECD's Continuous Roll-to-Roll Manufacturing Line

$8-10$

Features and Advantages of Continuous Roll-to-Roll Process

$10-11$

Task 1: Optimization of the Back-Reflector System

$12-14$

Task 2: Optimization of the Si-Ge Narrow Band-Gap Solar Cell

$15-16$

Task 3: Optimization of the Stable Efficiency of Photovoltaic Modules Introduction

Improvement to the continuous roll-to-roll solar cell deposition

QAQC process

A typical 2500 feet (19 kW) production run

Module Assembly

Improvements in module design to reduce losses

ECD's high efficiency $4 \mathrm{ft}^{2}$ production module

Stability efficiency of modules 
Task 4: Incorporating Microwave Plasma CVD Manufacturing Technology

Technical challenges

Development of microwave linear applicator technology

Technological developments

Materials \& solar cell characterization

Amorphous silicon \& solar cells

$25-26$

Amorphous silicon germanium alloys $\&$ tandem solar cells

Task 5: Material Cost Reduction

References 


\section{Preface}

This Annual Technical Progress Report covers the work performed by Energy Conversion Devices, Inc. (ECD) for the period of April 1, 1992, to March 31, 1993, under DOE/NREL Subcontract number ZM-2-11040-7 entitled "Continuous Roll-to-Roll a-Si Photovoltaic Manufacturing Technology". The following personnel participated in the research program:

H. Bianchi

R. Ceragioli

J. Chema

A. Christian

B. Clark

R. Crucet

$X$. Deng

J. Evans

G. Hajatpoor

C. Harrison

R. Himmler

M. Izu, Principal Investigator

R. Kopf

A. Krisko

A. Kumar

A. Myatt

K. Narasimhan

H. Ovshinsky

S.R. Ovshinsky

S. Sullivan

D. Tsu

K. Whelan

R. Woz

R. Young

We would like to thank Drs. H. Fritzsche, S. Guha, and J. Yang for helpful discussions. 


\section{List of Figures}

1: ECD's Continuous Roll-to-Roll a-Si Alloy Solar Cell Manufacturing Line

2: Continuous Roll-to-Roll Substrate Washing Machine

3: Continuous Roll-to-Roll Back-Reflector Machine

4: Continuous Roll-to-Roll Amorphous Silicon Alloy Deposition Machine

5: Continuous Roll-to-Roll Transparent Conductive Oxide Deposition Machine

6: J-V curve of triple-junction solar cell made in ECD's R\&D lab. This cell shows $13.7 \%$ record high conversion efficiency.

7: Quantum efficiency of the triple-junction solar cell showing $13.7 \%$ efficiency.

8: Structure of a triple-junction Spectrum-splitting solar cell made in ECD's continuous roll-to-roll manufacturing process

9A Back scattering image of a triple junction solar cell showing mechanical damage

9B A finished cell showing a hole present in a region of short

10: Plot of short-circuit current as a function of $\mathrm{Ag}$ thickness in back-reflector

11: Quantum efficiency curve of a triple-junction solar cell having less textured back-reflector

12: Quantum efficiency curve of a triple-junction solar cell having more textured back-reflector

13: Quantum efficiency curve of a single-junction nip device made on Ag/Zno back-reflector produced in ECD's continuous roll-to-roll process

14: Calculated and measured profiles of Ge concentration in the a-Si-Ge bottom cell intrinsic layer

15: J-V curve of a triple-cell (sample 1) utilizing a-Si-Ge bottom-cell with relatively high Ge content

16: J-V curve of a triple-cell (sample 2) utilizing a-Si-Ge bottom-cell with relatively low Ge content

17: Quantum efficiency curve of sample 1 triple-cell 
18: Quantum efficiency curve of sample 2 triple-cell

19: J-V curve of a-Si-Ge single-cell deposited on Ag/ZnO back-reflector

20: J-V curve of a-Si-Ge single-cell measured under filtered blue and red light.

21: Quantum efficiency curve for a-Si-Ge single-cell deposited on Ag/ZnO backreflector

22: Quantum efficiency curve for a triple-junction solar cell showing $40 \%$ quantum efficiency at $800 \mathrm{~nm}$

23: Schematic drawing of a QAQC coupon with 28 sub-cells $\left(7.35 \mathrm{~cm}^{2}\right.$ active area)

24: J-V curve of a $7.35 \mathrm{~cm}^{2}$ triple-junction sub-cell

25: J-V curve of a $0.25 \mathrm{~cm}^{2}$ triple-junction cell showing $11.1 \%$ efficiency

26: Quantum efficiency curve for the $0.25 \mathrm{~cm}^{2}$ triple-junction cell showing $11.1 \%$ efficiency

27: Cell efficiency of a $600 \mathrm{~m}$ production run

28: Open circuit voltage of a $600 \mathrm{~m}$ production run

29: Short circuit current of a $600 \mathrm{~m}$ production run

30: Fill factor of a $600 \mathrm{~m}$ production run

31: A schematic drawing of $1 \mathrm{ft} . \times 4 \mathrm{ft}$. module

32: Schematic drawing of a strip cell

33: I-V curve of a $1 \mathrm{ft} . \times 4 \mathrm{ft}$. module showing $9.5 \%$ initial aperture area module efficiency

34: I-V curve of a 1ft. $\times$ 4ft. module showing $8.0 \%$ stable aperture area module efficiency

35: Module efficiencies of two $4 \mathrm{ft}^{2}$ modules as a function of light soaking time under one sun

36. Schematic of the deposition chamber showing the MW feed-through and the Linear applicator on the inside of the chamber, along with other major components.

37. (a) Modified High Power MW Feed-Through, (b) Linear Applicator showing slot, (c) Applicator cross section. 
38. PDS data for MW deposited a-Si:H film.

39. Microwave a-Si:H single junction solar cell J-V curve (a) AM1.5 illumination, (b) Red and Blue response.

40. Si:Ge Alloy composition vs. gas composition.

41. Double-Junction (Tandem) solar cell with MW deposited a-Si:Ge bottom intrinsic layer, J-V curve (Pmx $\left.=7.2 \mathrm{~mW} / \mathrm{cm}^{2}\right)$

42: Low-cost marine plywood module

\section{List of Tables}

1: Production Historian Records

2: Statistical data for J-V curves of 28 cells on a QAQC coupon

3: Average cell performance data of coupons throughout an entire run.

4: Grid/bus barlencapsulation losses. Theoretical vs. actual

5: Light soaking test data of two $1 \mathrm{ft} \times 4 \mathrm{ft}$ triple-junction modules (Module 27 and Module 28).

6: Cost-reduction summary for Germane and disilane gases

7: Summary of assembly material cost reduction for the low-cost marine plywood module 


\section{Executive Summary}

\section{Objectives}

The overall objective of this three-year program is to advance ECD's roll-to-roll, triplejunction photovoltaic manufacturing technologies, to reduce the module production costs, to increase the stabilized module performance, and to expand the commercial capacity utilizing ECD technology.

The specific three-year goal is to develop advanced large-scale manufacturing technology incorporating ECD's earlier research advances with the capability of producing modules with stable $11 \%$ efficiency at a cost of approximately $\$ 1.00$ per peak watt.

Major efforts in the first year, Phase I, were the optimization of the high-performance back-reflector system, Task 1; the optimization of a-Si-Ge narrow band-gap solar cell, Task 2; and the optimization of the stable efficiency of the module, Task 3. Our goal was to achieve a stable $8 \%$ efficient $1 \mathrm{ft}$. $x 4 \mathrm{ft}$. module. Also, the efforts include work on a proprietary, high deposition rate, microwave plasma, CVD manufacturing technology, Task 4; and on the investigation of material cost reduction, Task 5.

\section{Approaches}

We have performed manufacturing technology development work utilizing our advanced continuous roll-to-roll triple-junction a-Si alloy solar cell production line, which was engineered and manufactured by ECD. The production line consists of:

1. A continuous roll-to-roll substrate washing machine.

2. A continuous roll-to-roll back-reflector machine.

3. A continuous roll-to-roll amorphous silicon alloy deposition machine.

4. A continuous roll-to-roll transparent conductor deposition machine.

The production line produces triple-junction two band-gap a-Si alloy solar cells of a $\mathrm{Si} / \mathrm{Si} / \mathrm{Si}$-Ge structure on a $5 \mathrm{mil}$. thick, $14 \mathrm{in}$. wide, $2500 \mathrm{ft}$. stainless steel roll at a speed of $1 \mathrm{ft} . / \mathrm{min}$. This represents the world's first commercial production line which produces the most advanced high-efficiency amorphous $\mathrm{Si}$ alloy solar cells utilizing multi-junction spectrum-splitting cell design and high performance back-reflector.

\section{Major Accomplishments in Phase 1}

- A high-performance Ag/metal oxide back-reflector system was successfully incorporated in our continuous roll-to-roll commercial production operation for the first time.

- For the first time, the high quality a-Si-Ge narrow band-gap solar cells have been incorporated in a commercial continuous roll-to-roll manufacturing.

- We have demonstrated the continuous roll-to-roll production of high-efficiency triplejunction two band-gap solar cells consistently and uniformly throughout a $2500 \mathrm{ft}$. 
run with high yield. The average initial sub-cell efficiency and yield were $10.21 \%$ and $99.7 \%$, respectively.

- We have achieved $11.1 \%$ initial subcell efficiency of triple-junction two band-gap a$\mathrm{Si}$ alloy solar cells in the continuous roll-to-roll production line.

- The world's first $4 \mathrm{ft}^{2}$ PV modules were produced utilizing triple-cell spectrumsplitting solar cells manufactured in our commercial, contimuous roll-to-roll production line. These $4 \mathrm{ft}^{2}$ modules had $9.5 \%$ initial efficiency and $8 \%$ stable module efficiency.

- As the result of process optimization to reduce the layer thickness and to improve the gas utilization, $77 \%$ material cost reduction for germane and $58 \%$ reduction for disilane have been achieved. Additionally, we have developed a new low-cost module saving approximately $30 \%$ in assembly material costs. 


\section{Introduction}

During the past ten years, ECD has significantly advanced the development of materials, device designs, and manufacturing processes required for the commercial acceptance of photovoltaic technology ${ }^{1-17}$. Among these advancements, ECD pioneered and continues development of three key proprietary technologies, each technology having significant potential for achieving the cost goals necessary for widespread growth of the photovoltaic market: 1) a low cost, roll-to-roll continuous substrate thin-film solar cell manufacturing process, 2) a high efficiency, multiple-junction, spectrum-splitting thin-film amorphous silicon alloy device structure, 3) a high deposition rate, high gas utilization microwave plasma CVD process.

Commercial production of multiple-junction amorphous silicon alloy modules has been underway at ECD and its joint venture company since 1985 using ECD's proprietary rollto-roll process. United Solar Systems Corp., ECD's joint venture company in Troy, Michigan, recently announced that it will begin construction of a 10 Megawatt plant in Newport News, Virginia. This will be the worlds largest manufacturing facility for a-Si alloy triple-junction PV panels. Numerous advantages of this roll-to-roll a-Si technology have been demonstrated. These advantages include relatively low semiconductor material cost, relatively low process cost, a lightweight, rugged and flexible substrate that results in lowered installed costs of PV systems, and environmentally safe materials.

Under this Phase 2A Photovoltaic Manufacturing Technology (PVMAT) Program, ECD proposed to advance its continuous roll-to-roll manufacturing technology and develop the capability of mass producing triple-junction multiple band-gap a-Si alloy photovoltaic modules with stable $11 \%$ efficiency at a cost of approximately $\$ 1.00$ per watt. Major efforts are focused on improving the stable efficiency of modules, increasing production throughput and reducing material and labor cost.

In order to achieve the high stable efficiency, ECD is further developing it's high volume manufacturing technology that can incorporate earlier ECD research advances in device efficiency through the use of multi-junction spectrum-splitting and high performance backreflector cell design. In this program period, Task 1: Optimization of the back-reflector system, Task 2: Optimization of the Si-Ge narrow band-gap solar cells, and Task 3: Optimization of the stable efficiency of photovoltaic modules, were directed towards achieving this goal.

In Task 4 we worked to increase the production throughput. We report progress made in the area of high deposition rate amorphous silicon alloy solar cell deposition utilizing proprietary microwave plasma CVD technology.

In Task 5 we addressed a number of other issues that significantly reduce module cost including the reduction of the cost of gases utilized in our proprietary narrow-band-gap materials. 


\title{
ECD'S a-Si Alloy PV Manufacturing Technologies
}

\author{
ECD's Continuous Roll-to-Roll Manufacturing Line
}

In ECD's current 2 Mega watt PV Manufacturing line, we deposit triple-junction two band-gap a-Si alloy solar cells in a continuous roll-to-roll process on a 5 mil thick, 14 inch wide and 2500 feet long web of stainless steel at a speed of $1 \mathrm{ft} / \mathrm{min}$, Figure 1 illustrates ECD's current manufacturing line.

The front end facility of the manufacturing line consists of four continuous roll-to-roll machines:

1. Substrate Washing Machine

Prior to the film deposition, the stainless steel roll purchased from a supplier is loaded into a substrate washing machine. The washing machine is a continuous roll-to-roll processing system that transports the stainless steel web through a detergent cleaning station, multiple deionized water rinsing baths, and an infrared oven drying stage, to produce clean, dry, particle-free substrate suitable for amorphous silicon deposition. Figure 2 is a picture of ECD's roll-to-roll substrate washing machine.

\section{Back-Reflector Machine}

After washing and drying, the roll is loaded into a back-reflector machine. The back-reflector machine is also a continuous roll-to-roll processing system that deposits a reflective metal layer and a metal oxide layer on the cleaned, stainless steel web. Both the metal and the metal oxide layer are vacuum deposited by DC magnetron sputtering on a heated substrate.

The metal adheres to the stainless steel and texturizes the surface to provide a diffuse, reflective layer with higher reflectivity. This enhances absorption of the infrared portion of the solar spectrum by providing increased optical path length for reflected light in the thin film solar cell structure and by providing more reflection. The metal and oxide layers provide ohmic contact to the solar cell as . well as improved infrared response. Figure 3 is a picture of ECD's continuous roll-to-roll back-reflector deposition machine.

3. Amorphous Silicon Alloy Deposition Machine.

After the back-reflector deposition, the roll is loaded into the amorphous silicon alloy deposition machine. This machine is a continuous roll-to-roll RF-plasma CVD processing system that produces, in a single pass, sequentially deposited thin films of doped and undoped amorphous silicon alloy semiconductors. Mixtures of feedstock gases are decomposed at a pressure of approximately 1 Torr in a series of RF CVD plasma chambers to deposit amorphous materials continuously on the coated stainless steel substrate that is heated to approximately $250^{\circ} \mathrm{C}$ to $300^{\circ} \mathrm{C}$. The multi-section amorphous silicon alloy deposition machine consists of a pay- 
Figure 1. ECD's Continuous Roll-to-Roll a-Si Alloy Solar Cell Manufacturing Line

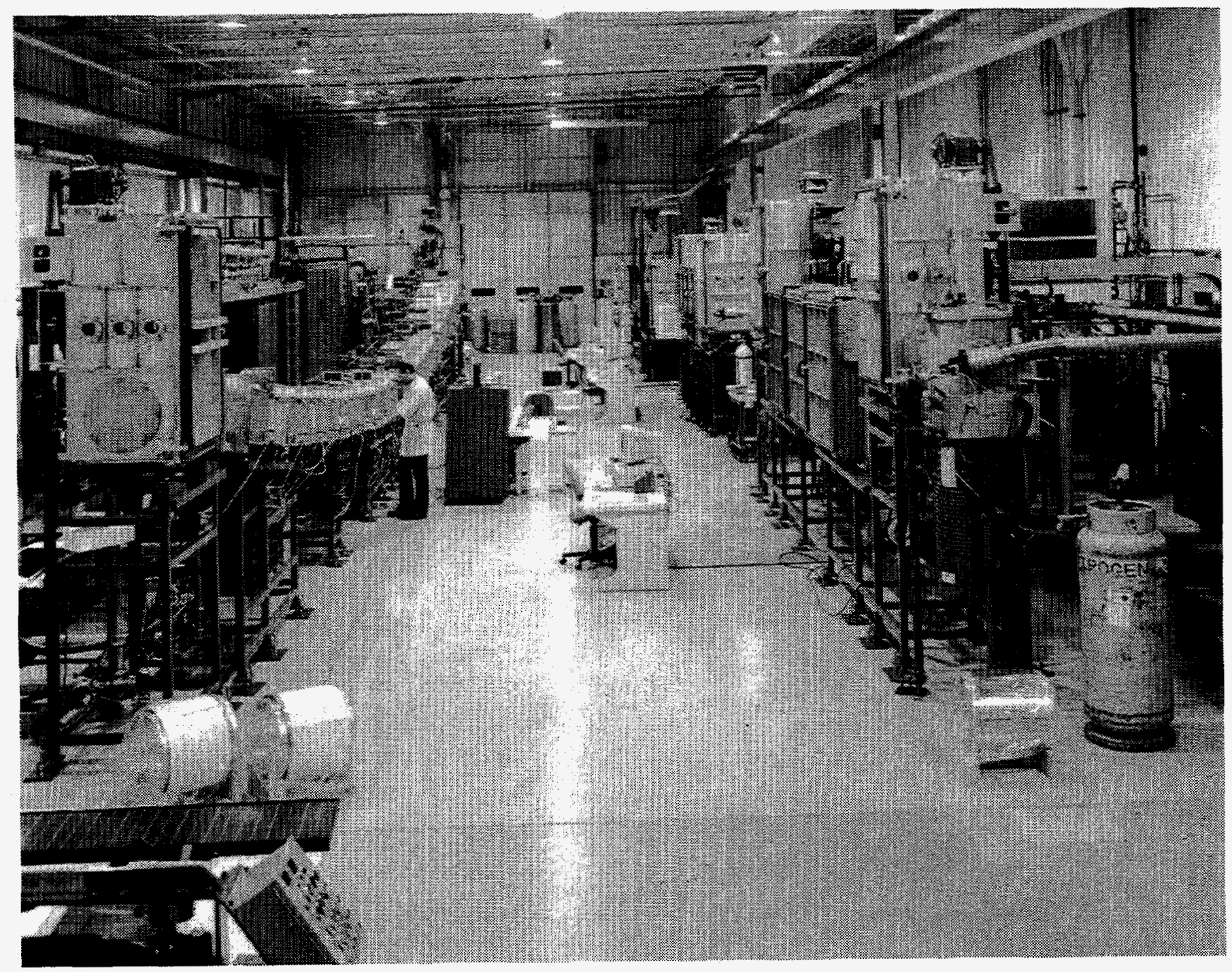


Figure 2. Continuous Roll-to-Roll Substrate Washing Machine

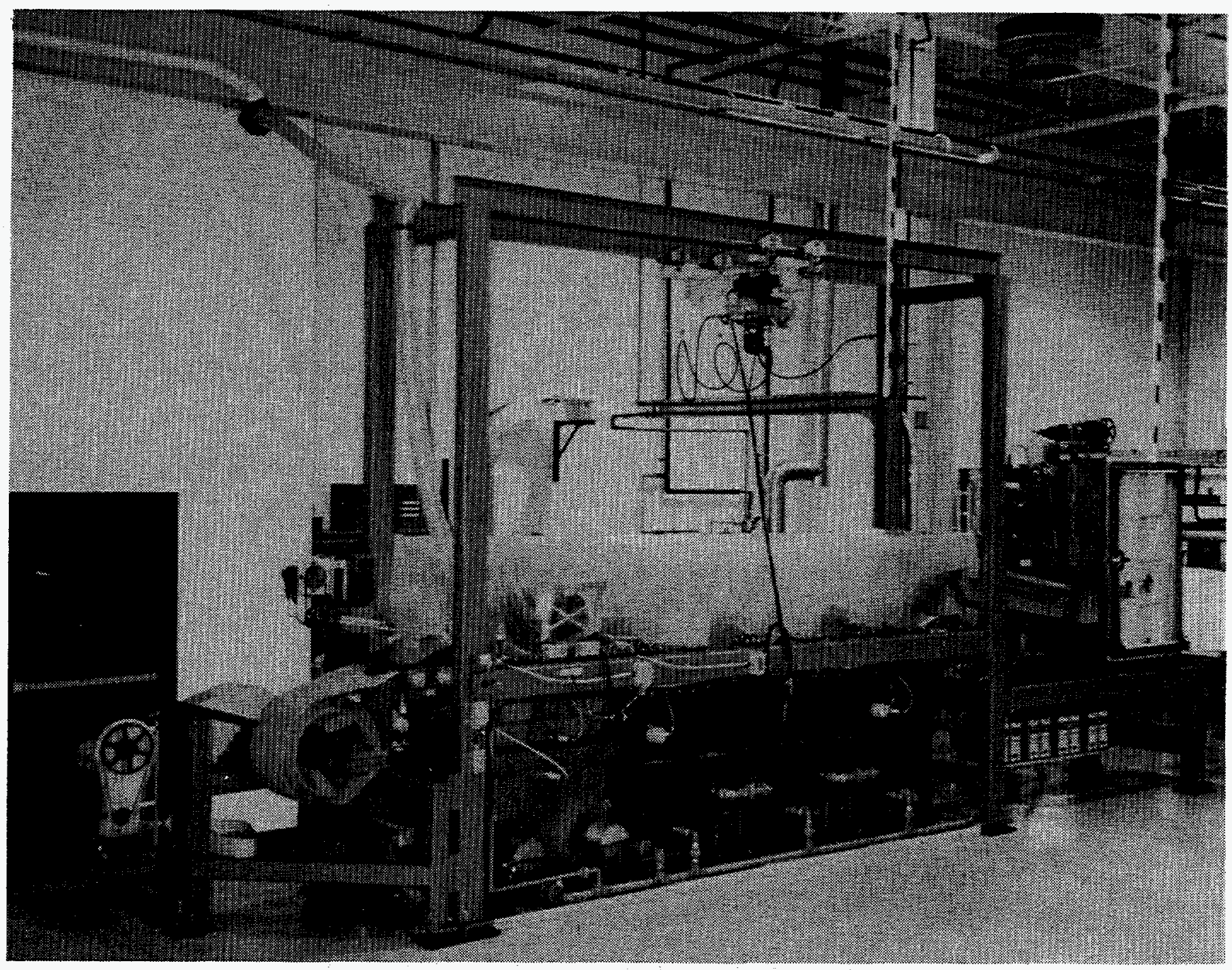


Figure 3. Continuous Roll-to-Roll Back-Reflector Machine

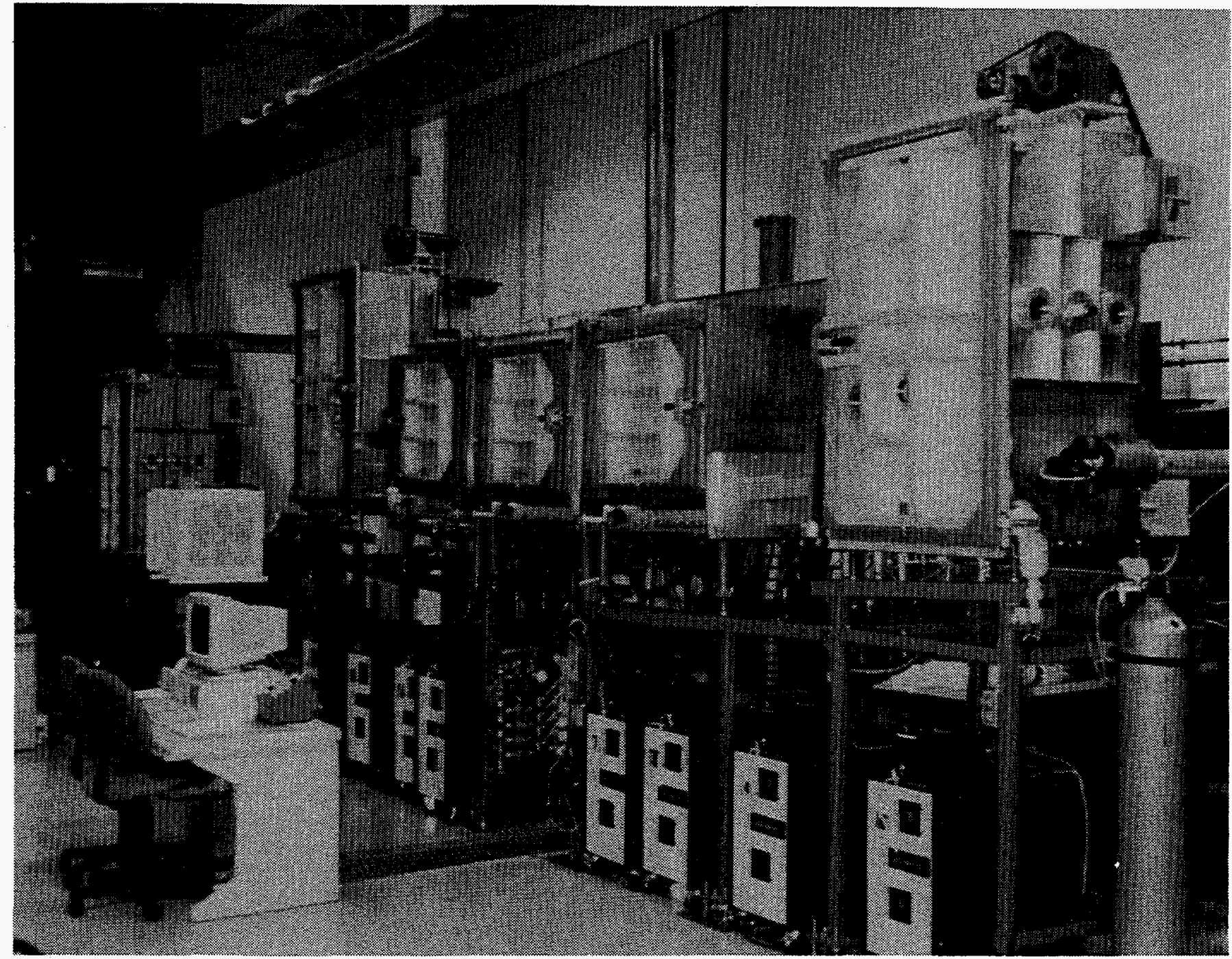


off chamber section, nine process chamber sections for the triple device structure and a take-up section. The process gas mixtures in each section are dynamically isolated from adjacent sections by proprietary "gas gates." The "gas gates" utilize laminar gas flow through constant geometrical cross section conduits in a direction opposite to the diffusion gradient of the dopant gas concentrations. In this way, migration of dopants between chambers is essentially eliminated and gas mixtures in adjacent chambers are effectively isolated even though no actual physical impediment is present. Substrate transport is accomplished with controlled tension and magnetic rollers for accurate positioning of the substrate in the various process chambers. The web is steered in the take-up chamber to insure that the substrate is properly wound. Substrate passage through the process chambers is such that deposition takes place on the underside, which minimizes film defects due to particulate accumulation. The current production equipment has nine RFplasma deposition chambers to produce a-Si/a-Si/a-Si-Ge triple-junction two band-gap solar cells. Figure 4 is a picture of ECD's continuous roll-to-roll a-Si alloy deposition machine.

\section{Transparent Conductor Deposition Machine}

The solar cell roll is then transferred to the transparent conducting oxide (TCO) deposition machine. This machine is a continuous roll-to-roll processing system which vacuum deposits a transparent electrically conductive layer on top of the solar cell structure. The process uses reactive evaporation of metal in an oxygen atmosphere. The substrate is heated to approximately $200^{\circ} \mathrm{C}$ during this deposition process. The TCO layer has two functions. First, it provides an electrical top contact between the current generating photovoltaic layers and the current collection grid. Second, its thickness is chosen so that it acts as an antireflective coating to the amorphous silicon alloy to give higher utilization of incident light. Figure 5 is a picture of ECD's continuous roll-to-roll transparent conductor deposition machine.

These four continuous roll-to-roll machines are highly automated. Sophisticated history records are obtained during the deposition. Table 1 is a list of the deposition conditions we recorded for each process run. We are able to trace back the actual deposition conditions throughout each process for every module we build.

The PV.module assembly process consists of the following procedures:

\section{Slabbing}

A finished roll of TCO coated a-Si solar cell material is cut by a slab cutter into 16" long, 14" wide "slabs".

\section{QA/QC}

Four inch by fourteen inch samples are manually sheared and processed into test solar cells for QC qualification of each 2,500 foot roll. 
Figure 4. Continuous Roll-to-Roll Amorphous Silicon Alloy Deposition Machine

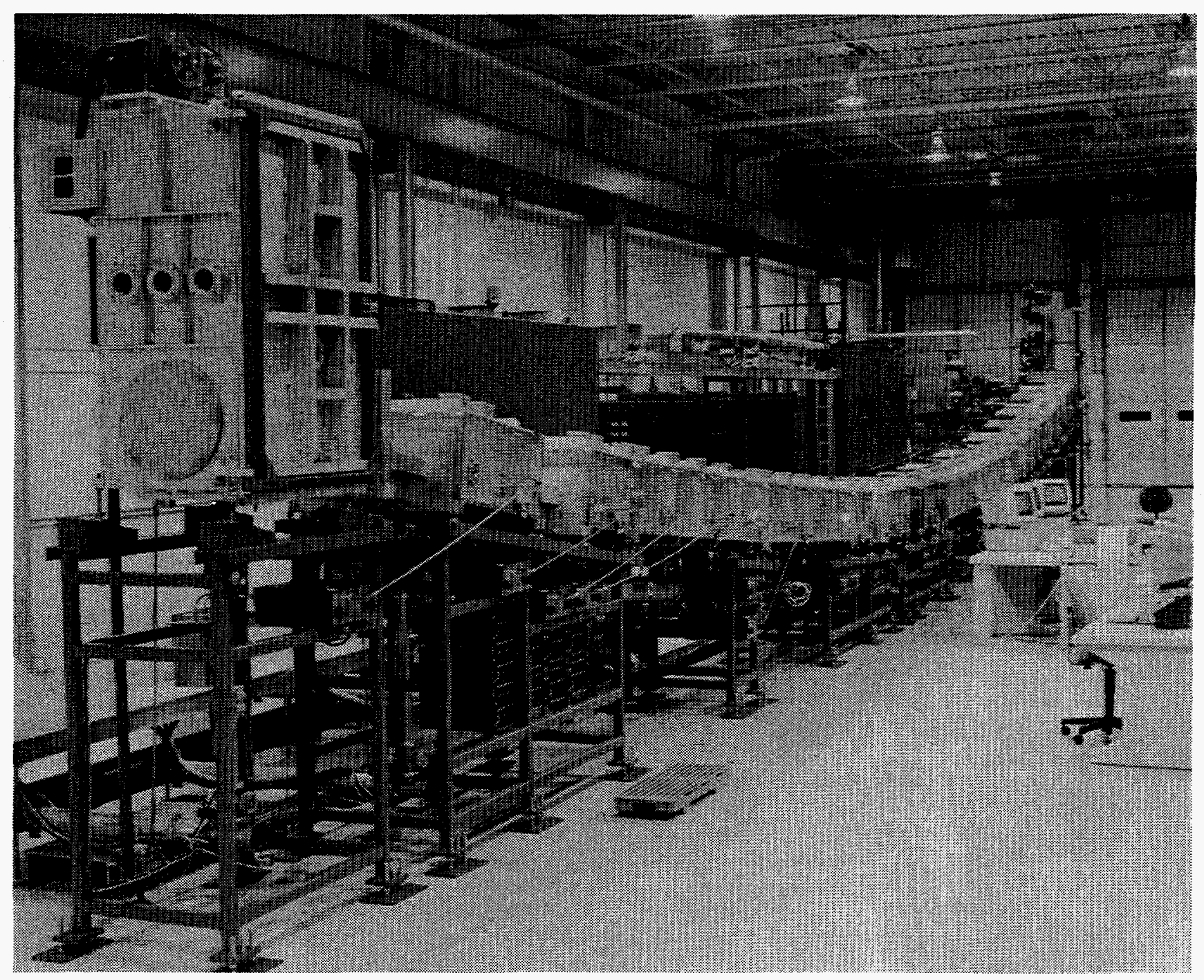


Figure 5. Continuous Roll-to-Roll Transparent Conductive Oxide Deposition Machine

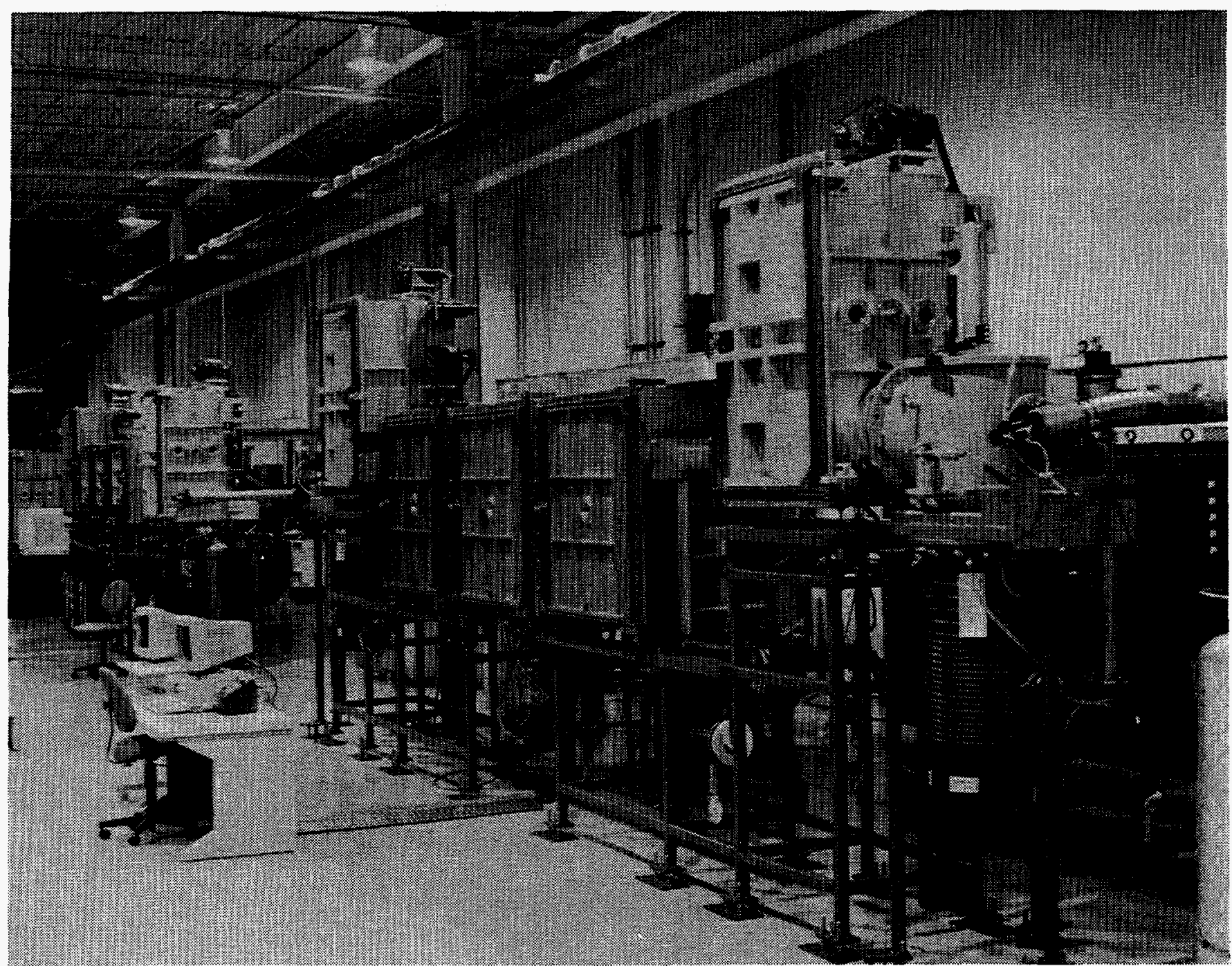


List of variables recorded in computer historian program for each run on ECD production machines recorded every 30 seconds (every 6" of web process travel)

In all machines:

Web totalizer (measurement of web processed)

Web speed

Web tension

Web steering

all alarms and events per run are recorded on printer and within a dedicated paragon file.

Web Washing Machine:

Temperature - 8 places

Wash tank detergent conductivity

Deionized water resistivity

Back-Reflector Sputtering Machine:

Sputtering cathode power - 7 units

Temperature -7 zones

Gas flow - 3 lines

Pressure - 4 places

a-Si alloy PECVD Machine:

RF power - 23 units

Temperature - 55 zones

Gas flow - 55 lines

Vacuum pressure - 16 places

Throttle valve position - 16 places

Baratron safety blocking valve positions - 16 places

TCO Evaporation Machine:

Source temperature -6 places

Dep. rate on crystal monitor - 6 places

Oxygen glow

Pressure - 5 places 
3. Scribing

TCO scribing is achieved by a semi-automatic screen printing process. The TCO etching paste is screen printed in a selected pattern and the etch process is activated by heating. After the etch is completed, remnants of the etching paste are removed by rinsing in an agitated aqueous cleaning bath.

4. Short Passivation

Defects in the solar cell that could give rise to electrical shorts on the coated web are electrically isolated by electrolytically converting the transparent conductor into an insulator at the defect sites through a proprietary process ${ }^{9}$. This short passivation operation involves treating the web with electrolyte solution and subjecting the cell to reverse electrical bias. After short passivation, the residual electrolyte is rinsed off with deionized water, and the web is dried with hot air.

\section{Screen Print Grid Pattern}

To aid current collection, a silver grid pattern is screen printed on the cell. This is followed by an IR curing step.

6. Final Assembly

- Cell Cutting: The slabs are sheared into strips, and qualified for their performance.

- Cell Interconnect: Cells are interconnected to make the cell block assembly. Suitable fixtures are provided to ease the assembly process.

- Laminating: The finished cell block is laminated in a vacuum laminator between two polymer sheets. The polymer sheets are chosen to provide clear front cover and pigmented back cover. Tefzel and EVA are used for the front cover.

- Module Finishing: The laminated cell block is trimmed to size and a junction box is attached. Other framing and connector details are added for specific products.

- Testing and Packaging: The module is finally tested in a solar simulator that measures the I-V curve of the finished modules under simulated AM 1.5 conditions, providing a printout of the I-V characteristics. Modules are then packaged, ready for shipment.

\section{Features and Advantages of ECD's PV Manufacturing Line}

1. Spectrum Splitting, Triple-Junction Cell Design

The key feature of our continuous roll-to-roll production line is the use of triplejunction two band-gap solar cells with high quality, band-gap profiled a-Si alloy as the bottom cell intrinsic layer.

It has been demonstrated earlier in ECD's R\&D lab that a-Si alloy solar cell devices with a-Si/a-Si/a-SiGe triple-junction design achieved the highest efficiency with better stabilitys. Figure 6 shows the J-V characteristics of such a triple-junction small device fabricated in ECD's laboratory. Figure 7 shows the quantum efficiency curve of this $13.7 \%$ efficiency device. 
Figure 6: J-V curve of triple-function solar cell made in ECD'S R\&D lab. This cell shows $13.7 \%$ record high conversion efficiency.

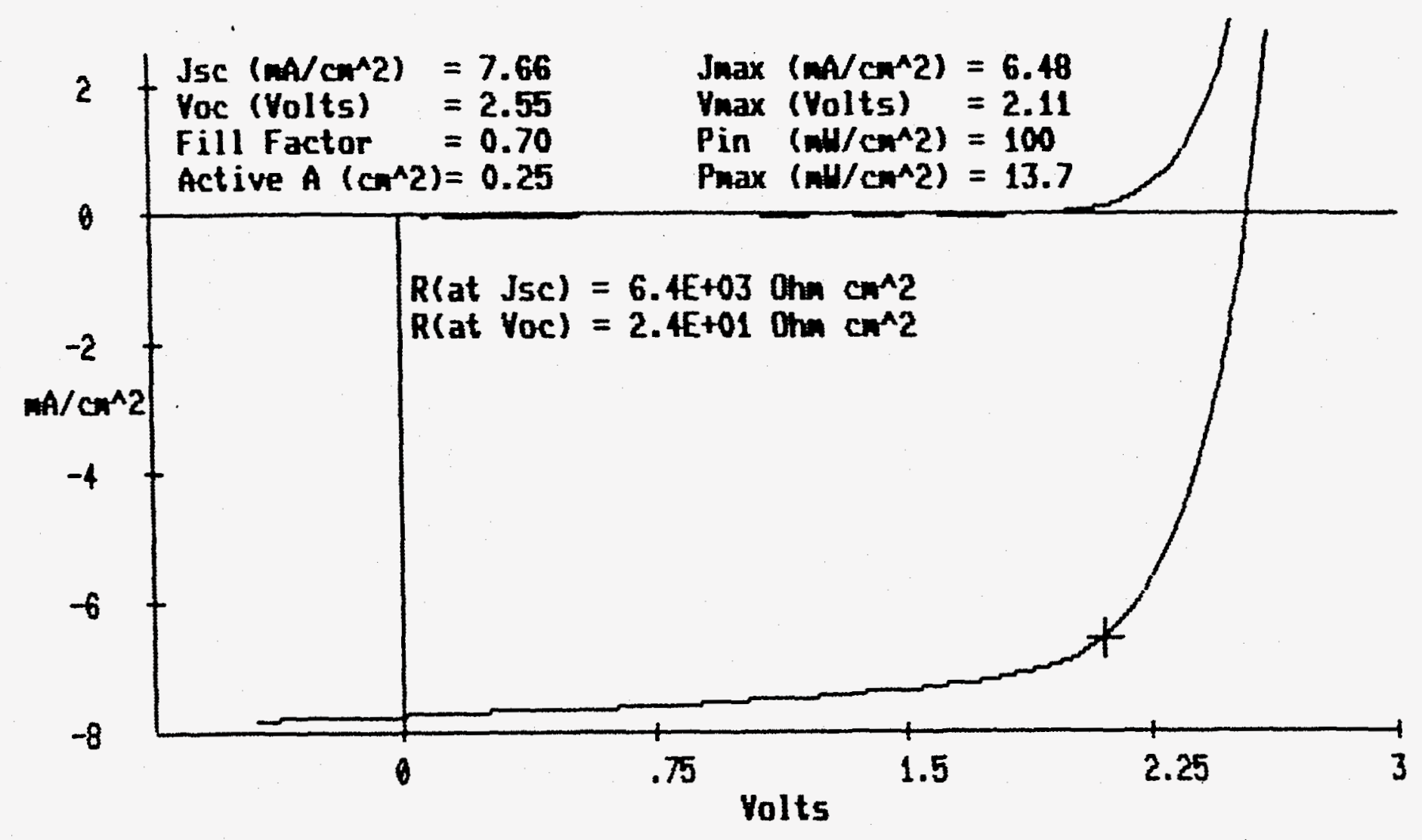




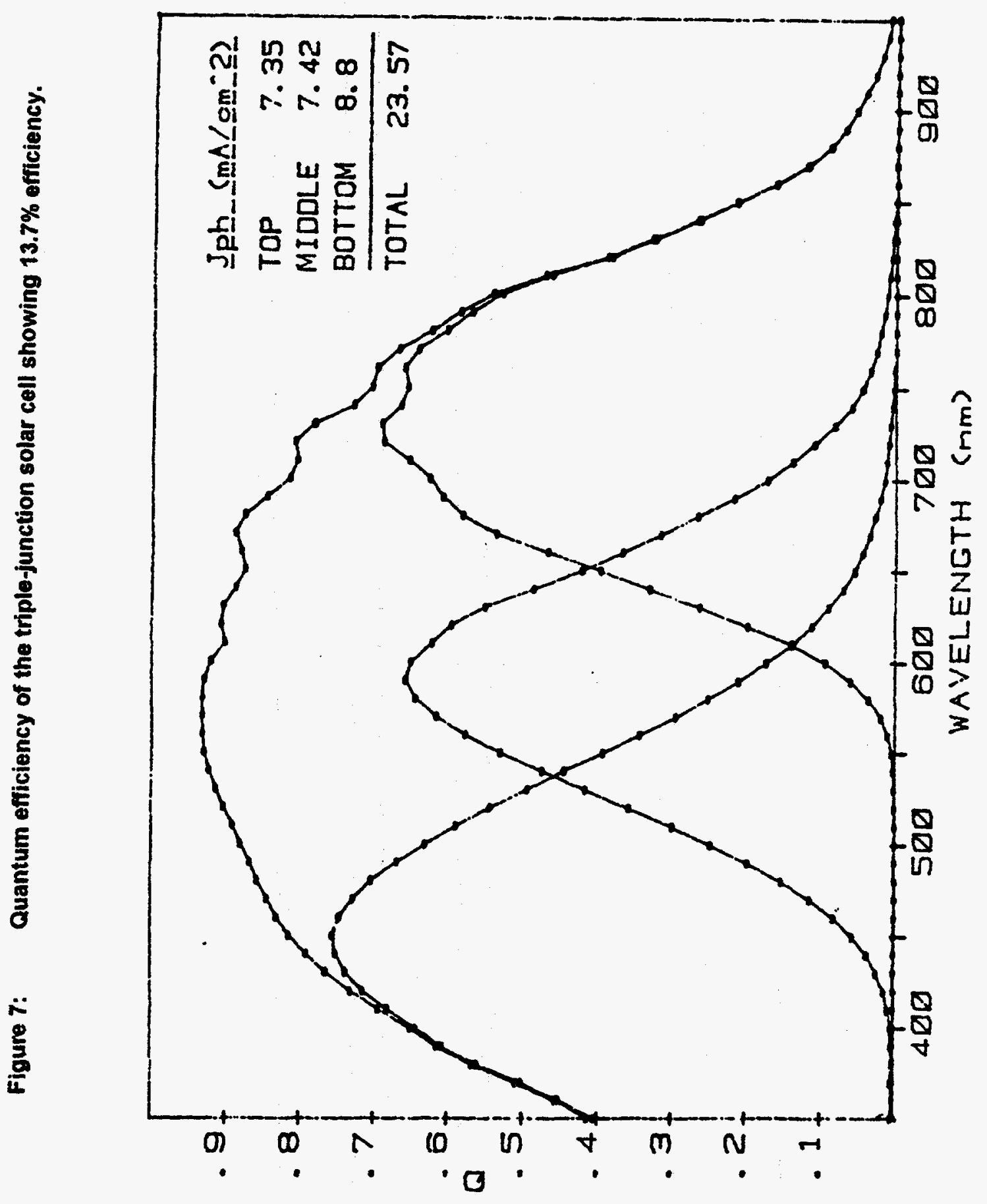


The manufacturing line has been designed and engineered to produce solar cells with this most advanced cell design to achieve the goal of high stable efficiency modules. Figure 8 shows the structure of solar cells produced in our manufacturing process.

2. Low cost, large scale continuous roll-to-roll operation.

In the roll-to-roll deposition of a-Si alloy solar cells, nine layers of a-Si alloys are produced in a single pass on to a $2500 \mathrm{ft}$. substrate. This stable steady state operation is reliable, and yields better uniformity. The operating cost, which includes maintenance and labor, is low.

3. Flexible thin stainless steel substrate.

The substrate is a 5 mil thick, 14 in. wide, $2500 \mathrm{ft}$. long stainless steel roll. It offers many advantages as compared to glass substrates. Stainless steel is breakage free during operation and handling. This thin stainless steel substrate can be heated and cooled quickly during deposition, no waiting time is needed for temperature stabilization. During the deposition, the substrate transport mechanism is simple and reliable, and component wear is much less. This keeps the maintenance cost low. Also, the substrate is light weight and flexible.

4. Light weight polymer encapsulated PV module.

EVA/Tefzel is used for the module encapsulation. Modules thus made are flexible, light weight, and nonbreakable. 
Figure 8: $\quad$ Structure of a triple-junction Spectrum-splitting solar cell made in ECD's continuous roll-to-roll manufacturing process

\begin{tabular}{|c|c|c|}
\hline & Grid & Screen Print \\
\hline \multicolumn{2}{|r|}{ TCO } & Reactive Evaporation \\
\hline p3 & microcrystalline Si alloy & PECVD \\
\hline i3 & a-Si alloy & PECVD \\
\hline n3 & a-Si alloy & PECVD \\
\hline $\mathbf{p 2}$ & microcrystalline Si alloy & PECVD \\
\hline i2 & a-Si alloy & PECVD \\
\hline $\mathrm{n} 2$ & a-Si alloy & PECVD \\
\hline p1 & microcrystalline Si alloy & PECVD \\
\hline i1 & a-SiGe alloy & PECVD \\
\hline nI & a-Si alloy & PECVD \\
\hline & Textured Back-reflector Ag/ZnO & Sputtering \\
\hline & \multicolumn{2}{|l|}{ Stainless Steel Substrate } \\
\hline
\end{tabular}




\section{Task 1: Optimization of the Back-Reflector System}

In our earlier manufacturing process, a textured $\mathrm{Al}$ alloy was used as a back-reflector. The high-efficiency, research-scale device (we have demonstrated $13.7 \%$ efficiency, the world-record efficiency for a-Si alloy solar cell, as shown in Figure 6) utilized textured $\mathrm{Ag} / \mathrm{ZnO}$ back-reflector that had a substantially higher reflectance and diffusivity than the $\mathrm{Al}$ alloy back-reflector, resulting in an enhancement of $\mathrm{Jsc}$ in our laboratory cells ${ }^{5}$. However, initial attempts to transfer this high-performance back-reflector technology to a manufacturing process had not been successful due to low yields. The object of this phase of our program was focused on achieving enhanced Jsc when Ag is used without suffering a reduction in yield due to shunting of the devices.

Material and process optimizations were carried out using a roll-to-roll back-reflector production machine, shown in Figure 3. The machine is equipped with eight DC magnetron sputtering cathodes. An upward sputtering configuration is used so that particulates do not accumulate on the web surface. Typically, two metal targets and six $\mathrm{ZnO}$ targets are loaded in the machine. The back-reflectors ( $\mathrm{Ag}$ and $\mathrm{ZnOx}$ ) were deposited sequentially at a speed of one foot per minute on a stainless steel roll that has a dimension of about $2500 \mathrm{ft}$., $14 \mathrm{in}$. wide, 5 mil thick.

The yield and short-circuit current obtained on cells employing the back reflector were evaluated. Current was evaluated using our roll-to-roll a-Si and top-conductor machines as well as a research scale load-lock deposition system. The research scale deposition system has separate chambers for depositing each doped layer and a-Si layer. It uses a RF parallel plate design and can deposit uniformly over approximately 2 in. $x 2$ in. area. A single $n-i-p$ a-Si cell was deposited simultaneously on a standard back-reflector and on the $\mathrm{Ag} / \mathrm{ZnO}$ back-reflector to be evaluated. Quantum efficiency measurements were used to compare the current of the cell with $\mathrm{Ag} / \mathrm{ZnO}$ back-reflector to the current for that same cell on previously characterized back-reflector.

We have studied two different back-reflector systems, $\mathrm{Ag} / \mathrm{ZnO}$ and $\mathrm{AlSi} / \mathrm{Ag} / \mathrm{ZnO}$. Initial testing shows that $\mathrm{Ag} / \mathrm{ZnO}$ back-reflector gave higher current in the solar cell, however, the yield was low due to shorts and shunts. The current was about $9.5 \%$ lower with the $\mathrm{AlSi} / \mathrm{Ag} / \mathrm{ZnO}$ system.

Causes for the low yield using the double-layered back-reflector system $\mathrm{Ag}, \mathrm{ZnOx}$ have been investigated by structural/morphological/chemical analyses of the sites that caused shorts. We have determined that the shorts are caused by defects in the layer structure due to mechanical damage and foreign materials incorporated in the deposited layer during processing. Figure 9A shows mechanical damage, (i.e., cracking of the film). The cracks are due to dimples in the $5 \mathrm{mil}$ stainless steel web created by metal particulates.

Figure 9B shows a hole in the a-Si layer that results in a short. This pinhole was created when foreign material such as dust or particulate was transferred to the front side of the web, particularly before or during deposition of the a-Si layer. 


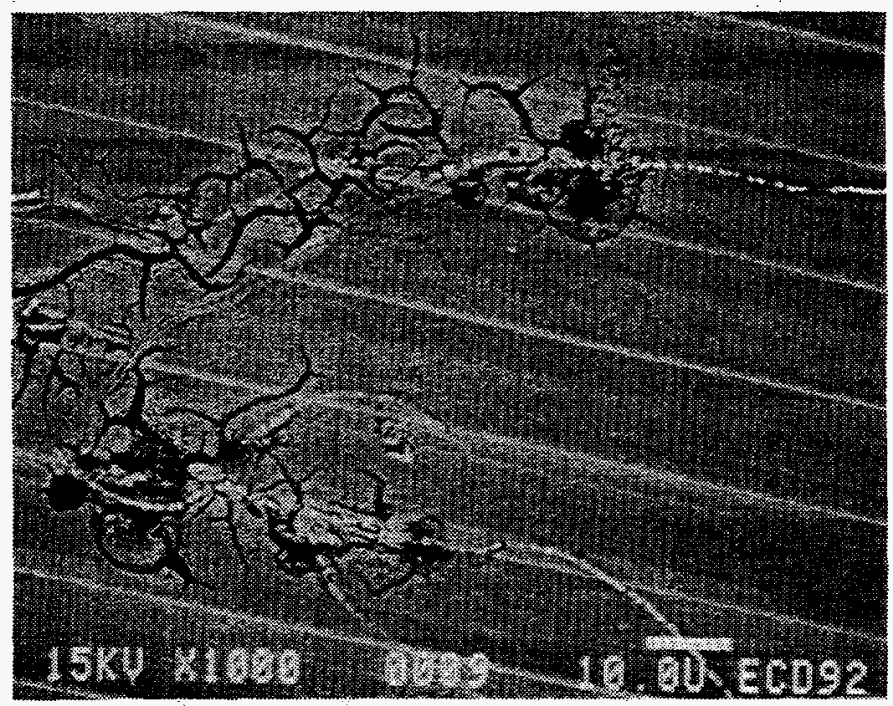

Figure 9A. Backscattering image of a triple-junction solar cell showing mechanical damage

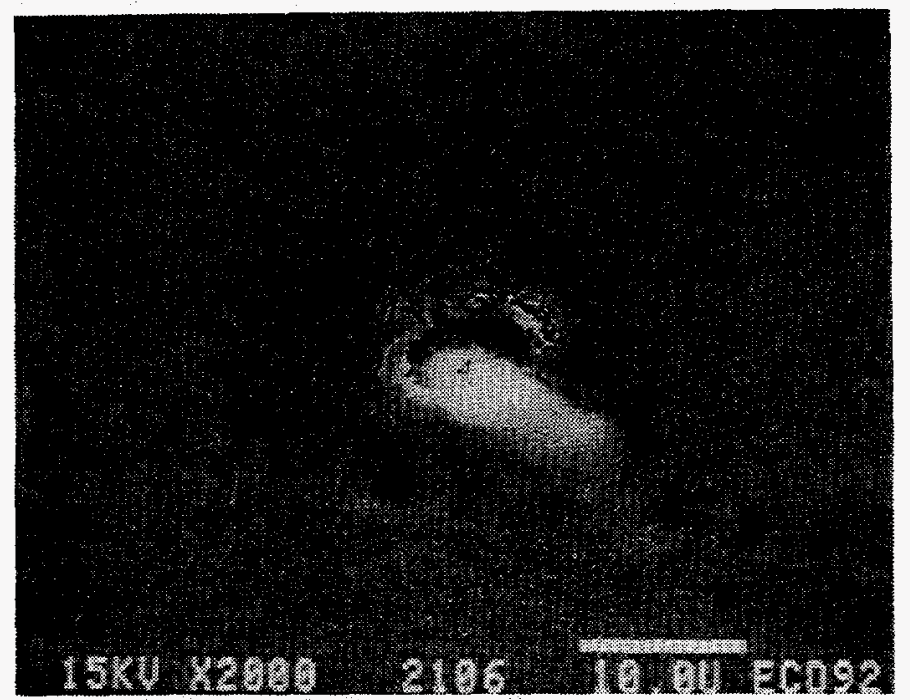

Figure 9B. A finished cell showing a hole present in a region of short. 
We incorporated several new designs for the production machine to improve the backreflector by reducing the mechanical damage such as dimples and scratches.

A new bearing design is incorporated that can transport the web in vacuum at high temperatures $\left(300^{\circ} \mathrm{C}\right)$ without contaminating the deposition. The improved bearing design eliminated the loss in yield due to scratches caused by stuck rollers.

We have identified that most dimples are caused by the particulates accumulated on the back side of the web. The particulates are collected in the take-up chamber by the roller that applies tension to the web and causes dimples on the web. A wiper is installed in the take-up chamber before the tension applying roller that effectively removes the particulates from the back-side of the web.

Several other modifications were made in the back-reflector deposition system to further reduce the occurrence of web dimples and scratches.

With the above improvements, we have effectively reduced the creation of shorts and shunts, and obtained high production yield for the high performance $\mathrm{Ag} / \mathrm{ZnO}$ backreflector system. For a $2500 \mathrm{ft}$. production run we have achieved average subcell yield of $99.7 \%$. This is the highest production yield ever achieved in a $\mathrm{Ag} / \mathrm{ZnO}$ back-reflector system.

The cell current was also optimized using the $\mathrm{Ag} / \mathrm{ZnO}$ back-reflector. Deposition conditions were adjusted for each layer of the $\mathrm{Ag} / \mathrm{ZnO}$ system to optimize the backreflector performance. Deposition temperature, as well as $\mathrm{Ag}$ and $\mathrm{ZnO}$ layer thickness, and rate of sputtering, were found to affect film quality. Figure 10 shows the dependence of solar cell current on the Ag layer thickness. The current improves with $\mathrm{Ag}$ thickness, presumably due to enhanced internal reflection from a rougher morphology. However, we begin to see a drop in subcell yield for thicker Ag layers. We adjusted the deposition to achieve improvements in the following four areas:

1. higher reflectance of $\mathrm{Ag}$ layer

2. better texture of $\mathrm{Ag}$ layer

3. less absorption in the $\mathrm{ZnO}$ layer

4. higher yield

Figure 11 is a quantum efficiency curve of a triple-junction a-Si alloy solar cell on an earlier $\mathrm{Ag} / \mathrm{ZnO}$ back-reflector. The quantum efficiency at long wave length region $(700 \mathrm{~nm}$ $-800 \mathrm{~mm}$ ) reflects the performance of back-reflector. After process optimization, we have improved the back-reflector quality as shown in Figure 12. The quantum efficiency curve on the improved back-reflector shows less evident interference fringes due to diffuse reflection, resulting in higher bottom cell current. For the same a-Si-Ge bottom cell, improved $\mathrm{Ag} / \mathrm{ZnO}$ back-reflector gives $7.43 \mathrm{~mA} / \mathrm{cm}^{2}$ in the bottom cell, as seen in Figure 12 , compared to $6.78 \mathrm{~mA} / \mathrm{cm}^{2}$ for the initial $\mathrm{Ag} / \mathrm{ZnO}$ back-reflector as seen in Figure 11 .

To qualify the back-reflector we also made single junction a-Si nip cells ( $-3000 \AA$ thick) on this back-reflector. Figure 13 is the quantum efficiency curve of such a a-Si device on an improved $\mathrm{Ag} / \mathrm{ZnO}$ back-reflector. The $16.3 \mathrm{~mA} / \mathrm{cm}^{2}$ short circuit current calculated from $\mathrm{Q}$ is about $17 \%$ higher than for previous $\mathrm{A} / \mathrm{ZnO}$ back-reflector. 
Figure 10: Plot of short-circuit current as a function of Ag thickness in back-reflector

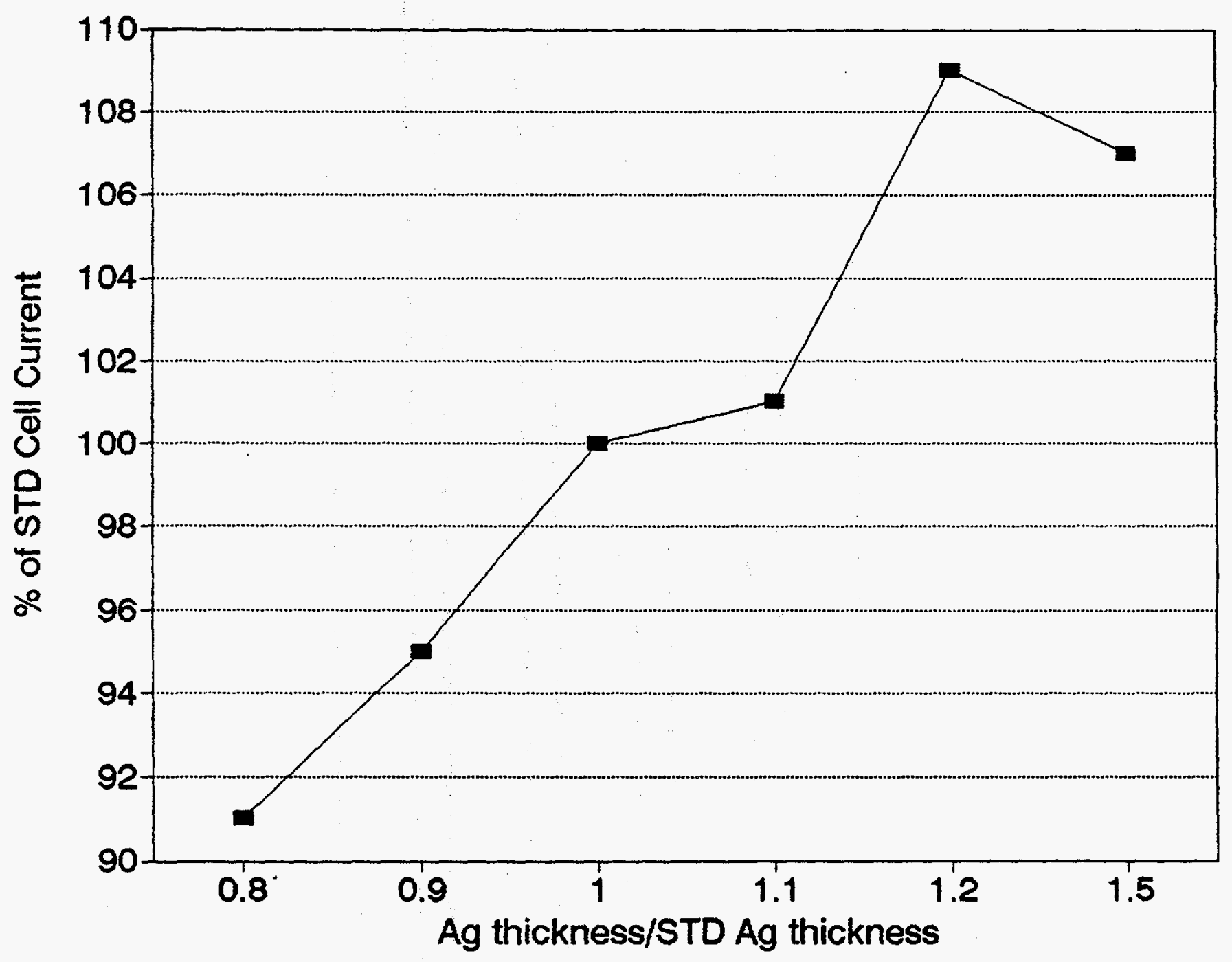



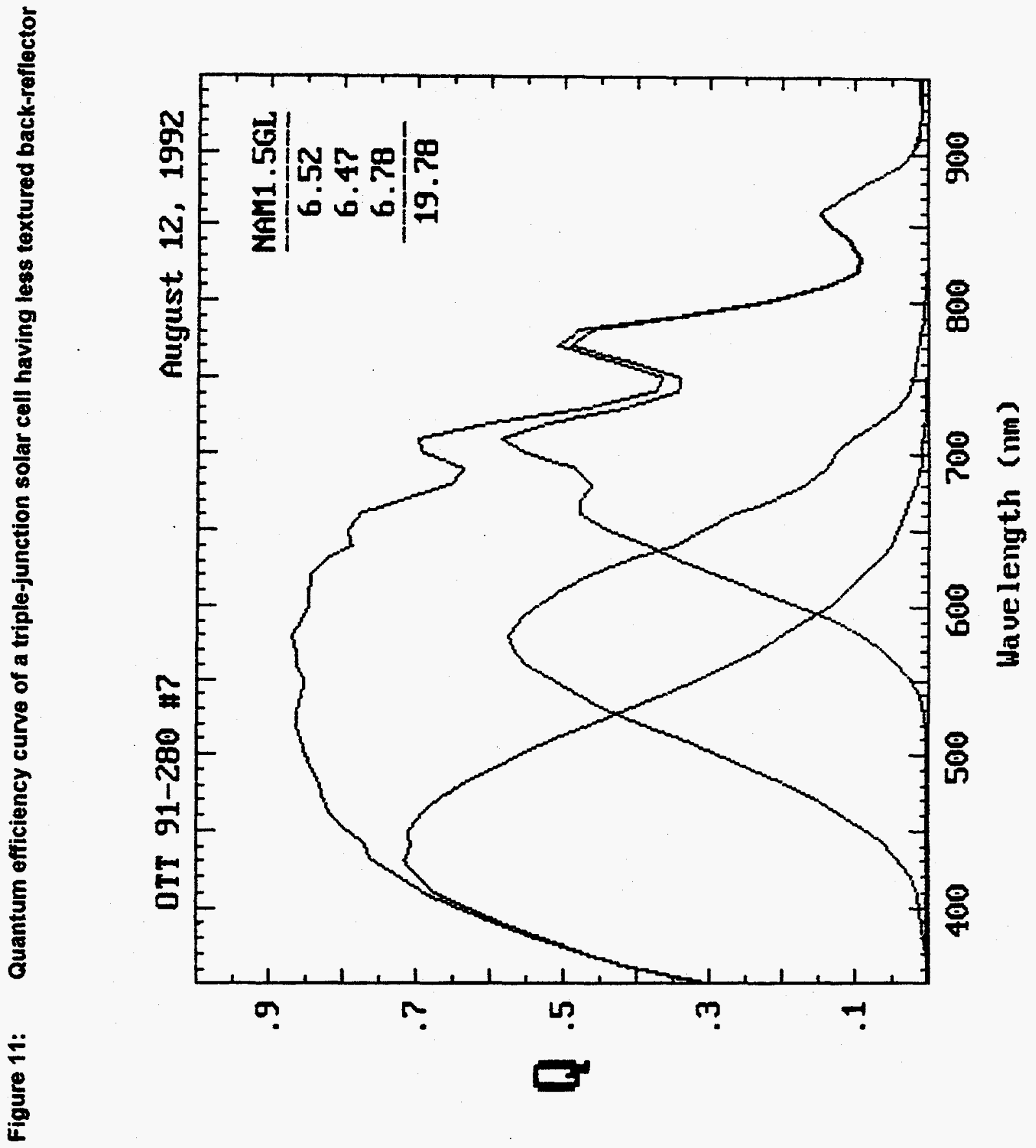
Figure 12: Quantum efficiency curve of a triple-junction solar cell having more textured back-reflector

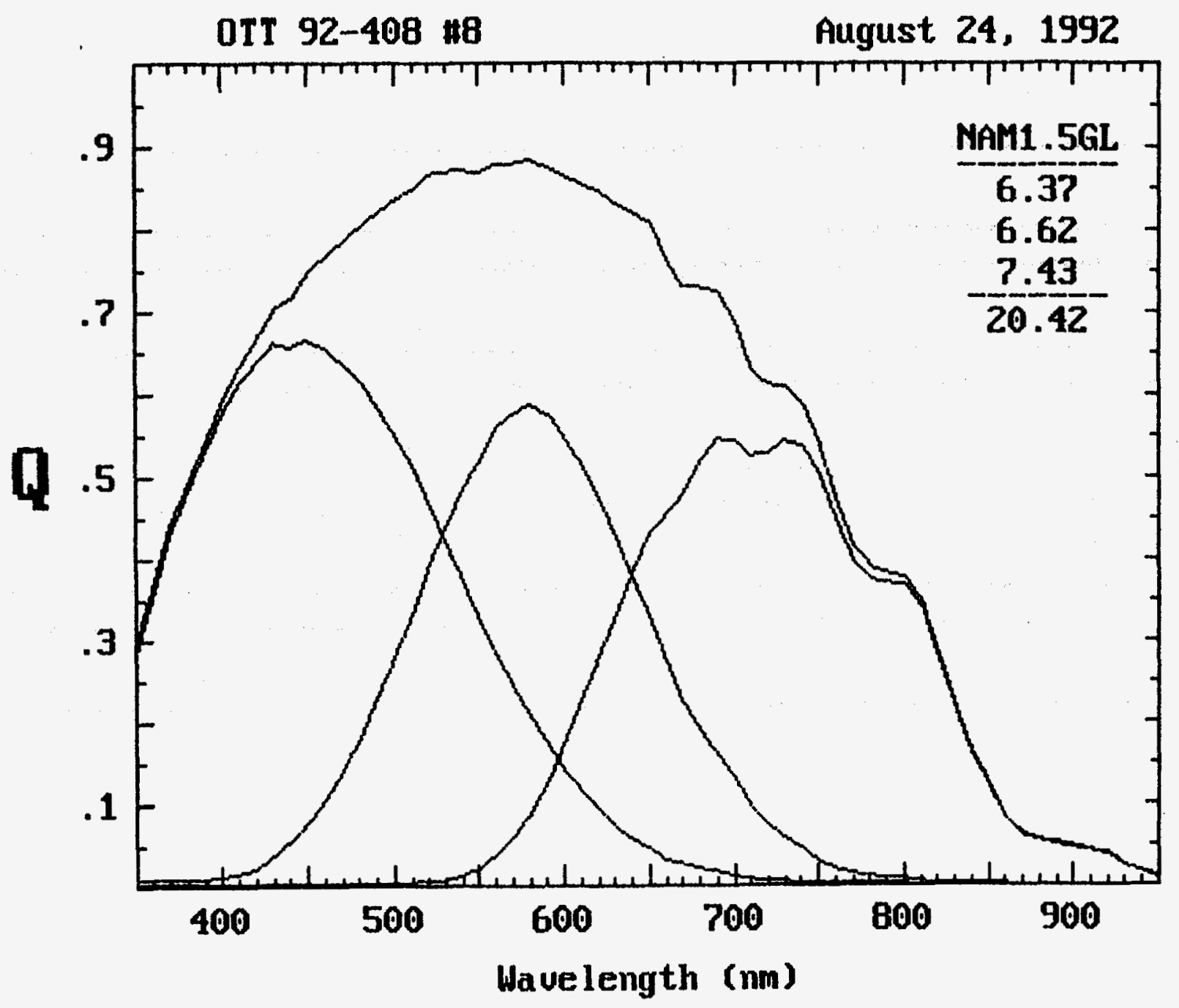




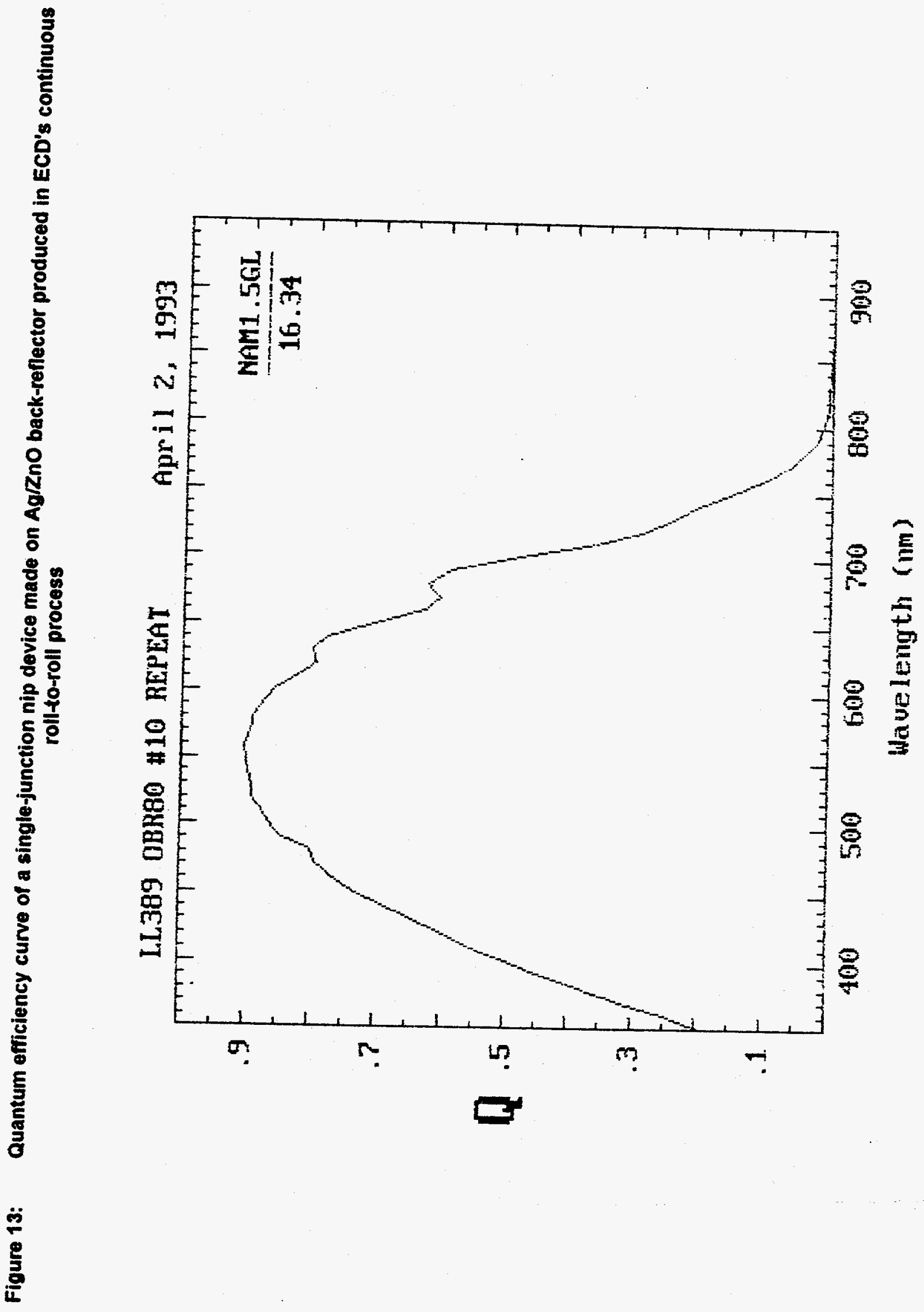


In summary, the high performance $\mathrm{Ag} / \mathrm{ZnO}$ back-reflector system, has for the first time, been successfully incorporated in a continuous roll-to-roll production line. We have achieved $99.7 \%$ average subcell yield for the $2500 \mathrm{ft}$. long production run. 


\section{Task 2: Optimization of the Si-Ge Narrow Band- Gap Solar Cell}

ECD's roll-to-roll a-Si alloy deposition machine, shown in Figure 2, produces a triplejunction two band-gap solar cell structure with a-Si-Ge as the bottom cell intrinsic layer. This is the first time that a narrow band-gap cell has been incorporated into a continuous roll-to-roll production process. We have used this machine to optimize the Si-Ge narrow band-gap solar cell. The bottom-cell section of the roll-to-roll process machine consists of three RF glow discharge CVD deposition chambers, a $\mathrm{nl}$ chamber for the $\mathrm{n}^{+} \mathrm{a}-\mathrm{Si}$ layer; a long il chamber for the a-Si-Ge layer; and a pl chamber, for the $\mathrm{p}^{+}$microcrystalline $\mathrm{Si}$ layer.

Band-gap profiling is an important tool for achieving higher efficiency as has been shown in earlier investigations at $\mathrm{ECD}^{14}$. In order to incorporate band-gap profiling capability in the continuous roll-to-roll machine, a proprietary gas distribution manifold and cathode configuration was designed and incorporated in the roll-to-roll machine. This gas distribution manifold delivers gas mixtures containing different amounts of $\mathrm{GeH}_{4}$ into different parts of the il chamber. The band-gap profiling is designed such that relatively higher $\mathrm{Ge}$ content is on the side of $i$ layer closer to the $\mathrm{p}^{+}$layer. With such a profiled band-gap, more light is absorbed near the $\mathrm{p}^{+}$junction to minimize the distance holes must travel to get collected. Also, the graded band-gap profiling induces an internal field to aid holes traveling toward the $\mathrm{p}^{+}$. a-Si-Ge narrow band-gap cell with such a profiled band-gap shows much better fill factor. Figure 14 shows the Ge concentration of films deposited at different parts of the il chamber, which corresponds to different depths in the il layer thickness. The left hand side is close to the $\mathrm{p}^{+}$layer. The calculated curve is obtained by calculating the delivered gas distribution. The measured $\mathrm{Ge}$ concentration was obtained from Auger sputtering depth profile. The calculated curve closely matches the measured curve, as is shown in Figure 14. This result demonstrates that our machine design for incorporating the band-gap profile is effective.

The a-Si interface layer between $\mathrm{il}$ and $\mathrm{pl}$ has also been optimized. A proprietary interface layer enhanced the Voc and fill factor.

The performance of the a-Si-Ge bottom-cell depends on Ge content, band-gap profile and the $i$ layer thickness. We investigated such relations systematically using a-Si-Ge singlecell stricture deposited in our roll-to-roll machine. We deposited a set of such cells with the same Ge content in the $i$ layer but with different degrees of profiling. The fill-factor of the cell increased as the profile became steeper. Especially important is the increase in the fill-factor measured under red light, which is the light that a-Si-Ge cell sees as the bottom cell of a triple-cell. When we further increased the degree of profiling, a loss in Voc became significant. We also studied the dependence of the bottom-cell on the Ge content with a fixed profile. We varied the band-gap from $1.4 \mathrm{eV}$ to $1.6 \mathrm{eV}$. When the $\mathrm{Ge}$ content was increased, Jsc increased due to the smaller band gap. However, the losses in Voc and fill-factor became significantly large at a high Ge content. The loss in fill-factor is due to the increased defect density in the a-Si-Ge alloy at a high Ge content. 


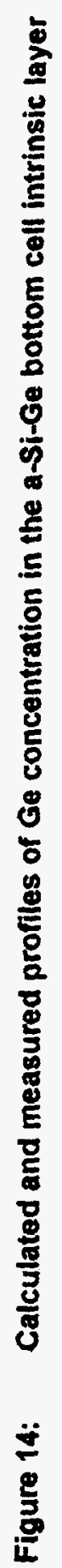

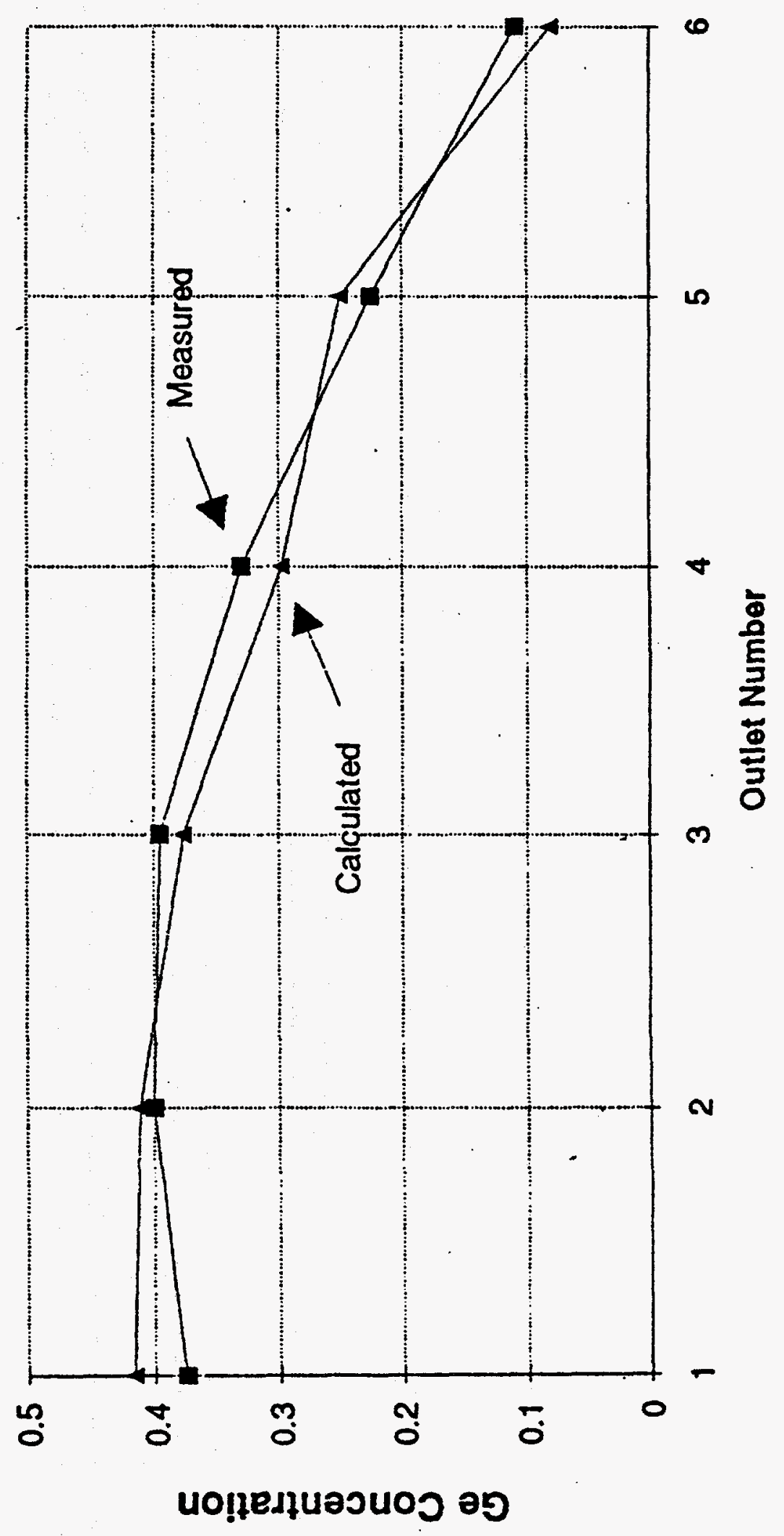


We have studied the dependence of cell performance on the Ge content, band-gap profiling, and thickness inside a triple-junction solar cell structure. In Figure 15 and Figure 16 we show the J-V characteristics of two triple-junction cells with identical structures except that the bottom cell $\mathrm{i}$ layers have different Ge content, band-gap profiling, and thickness. Sample 1 , having a bottom cell i layer containing more Ge and with a steeper profile, shows a higher fill-factor due to higher current density from the bottom component cell under AM1.5 illumination. Sample 2, having a bottom cell i layer containing less $\mathrm{Ge}$, with less profile and being thicker, shows higher Voc. The efficiencies of these two cells are the same, indicating that there is a trade-off between Jsc and Voc. In Figure 17 and Figure 18, we show the quantum efficiency curves of Sample 1 and Sample 2. Although the bottomcell of Sample 1 contributes relatively less Voc compared to that of Sample 2, it absorbs more light in the red and also, it has better fill-factor, hence it increases the overall fillfactor of the triple-cell.

We optimized the Ge content, degree of band-gap profiling, and the thickness of the bottom cell $i$ layer, based on the response of the cell under red illumination. Figure 19 shows the J$\mathrm{V}$ characteristics of a typical single-junction $\mathrm{Si}-\mathrm{Ge}$ cell deposited on $\mathrm{Ag}-\mathrm{ZnO}$ backreflector. Figure 20 shows the J-V measured under filtered blue and red light. The red fillfactor of this $\mathrm{Si}-\mathrm{Ge}$ cell was $59 \%$, as is seen in Figure 20. Figure 21 shows the quantum efficiency curve of this same cell. The relatively high red fill-factor and high response to the red suggest that this narrow-band-gap bottom-cell was well suited for use as the bottom-cell of triple-junction two band-gap solar-cell.

Using the optimized a-Si-Ge bottom cell in our a-Si alloy roll-to-roll deposition machine, we obtained a triple-junction solar-cell with $40 \%$ quantum efficiency, at $800 \mathrm{~nm}$. Figure 22 is a quantum efficiency curve of a triple-junction cell using such optimized a-Si-Ge bottom-cell. The fringes in the quantum efficiency curve are due to interference effect indicating the back-reflector texture is less than optimum. We see from the figure that $Q(800 \mathrm{~nm})=40 \%$ (after smoothing out the interference fringes).

As will be shown in Table 3 in the next section, Task 3, we have demonstrated the production of high quality a-Si-Ge solar cells on $2500 \mathrm{ft}$. production rolls in a highly uniform and consistent manner in our continuous roll-to-roll amorphous silicon alloy deposition machine. 
Figure 15: J-V curve of a triple-cell (sample 1) utilizing a-Si-Ge bottom-cell with relatively high Ge content

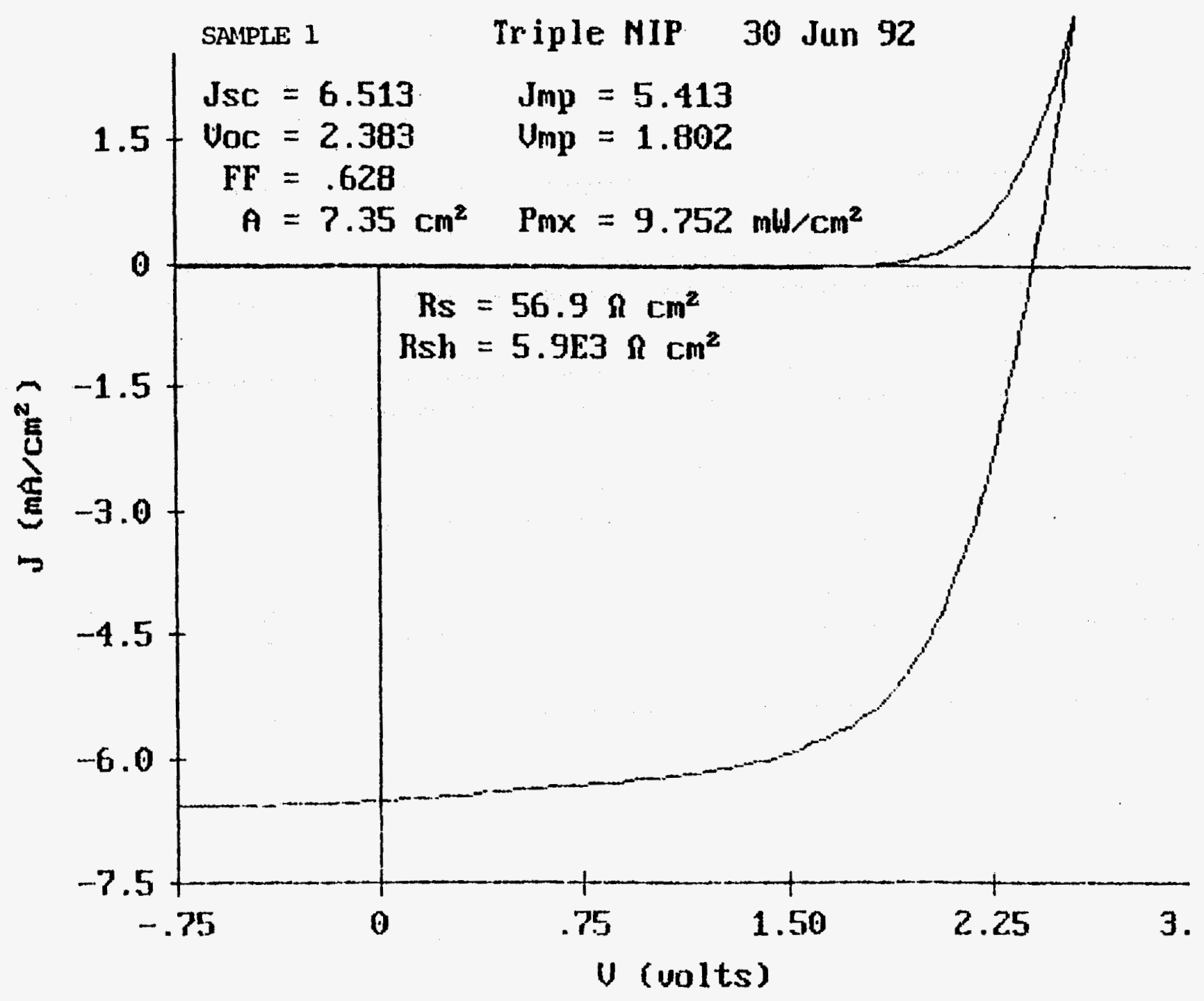


Figure 16: $J-V$ curve of a triple-cell (sample 2) utilizing a-si-Ge bottom-cell with relatively low $G e$ content

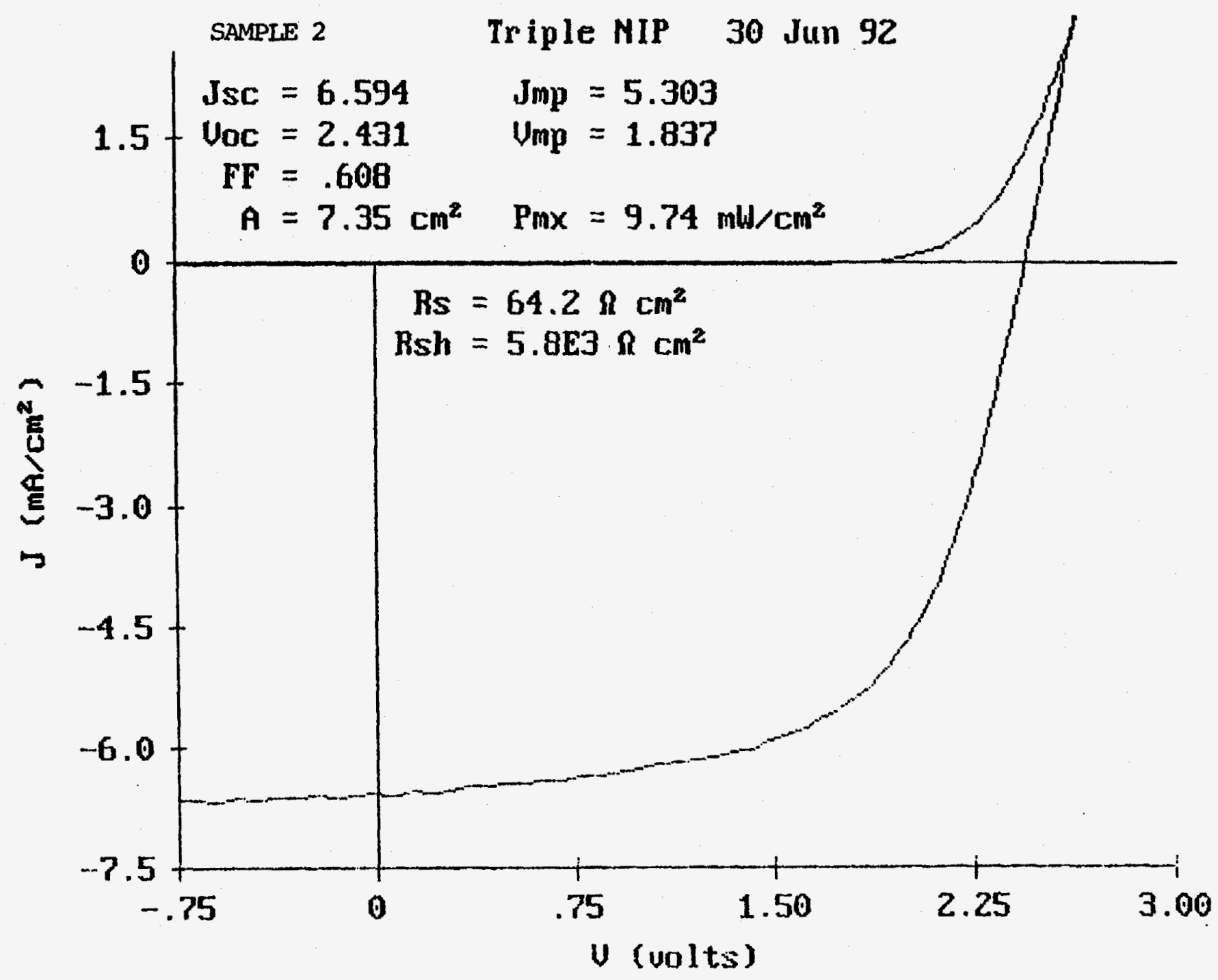


Figure 17: Quantum efficiency curve of sample 1 triple-cell

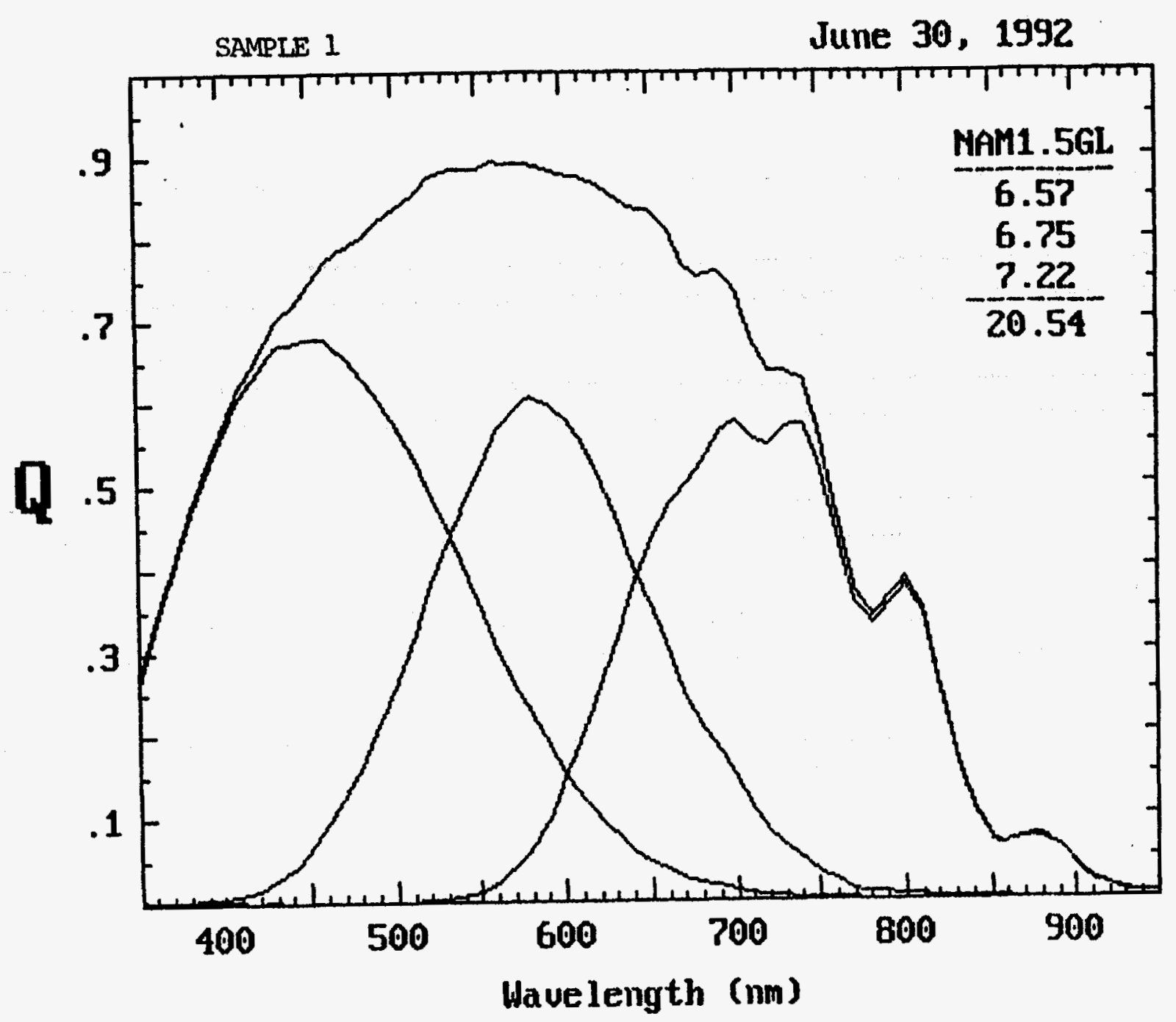


Figure 18: Quantum efficiency curve of sample 2 triple-cell

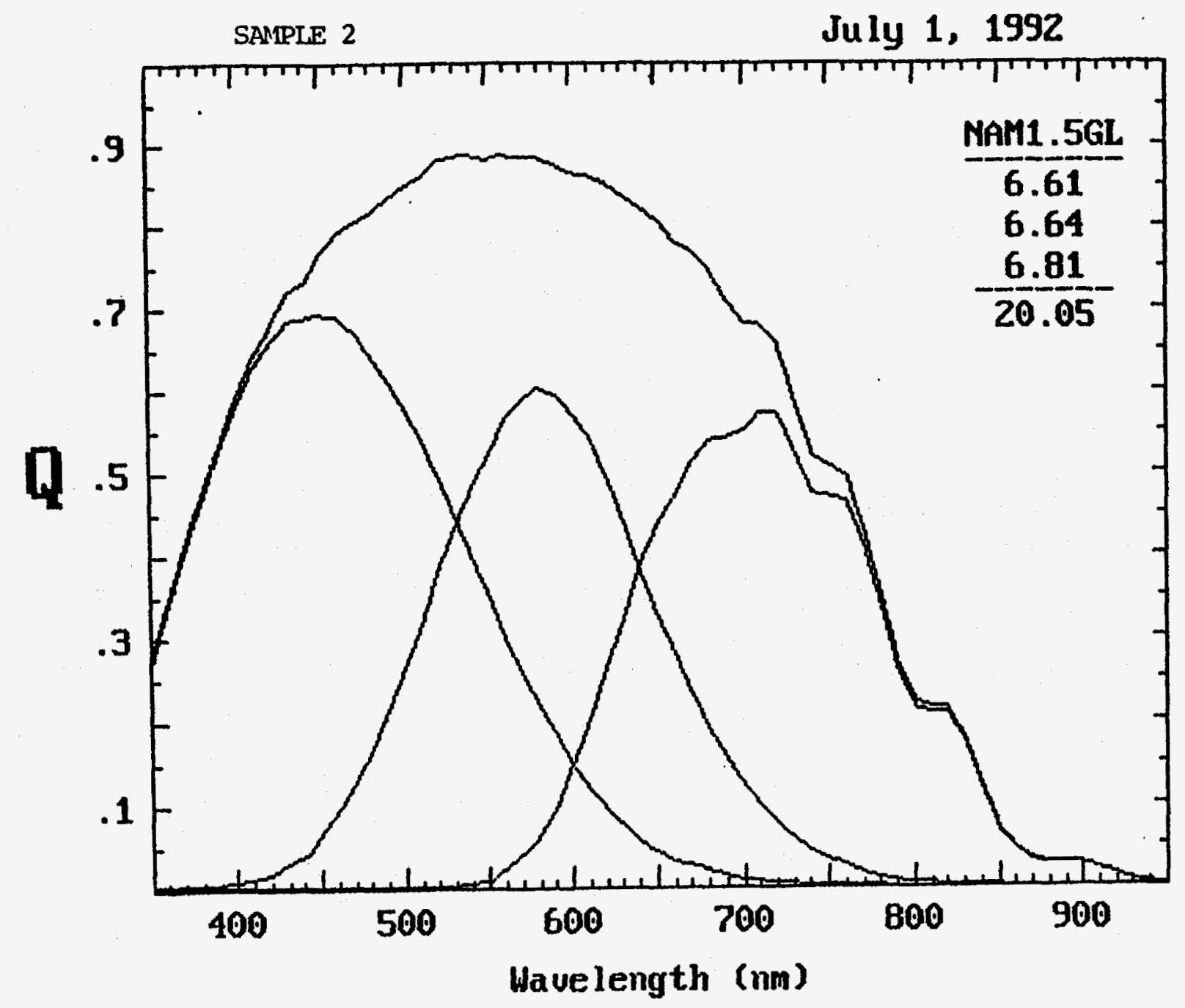


Figure 19: J-V curve of a-Si-Ge single-cell deposited on $\mathrm{Ag} / \mathrm{ZnO}$ back-reflector

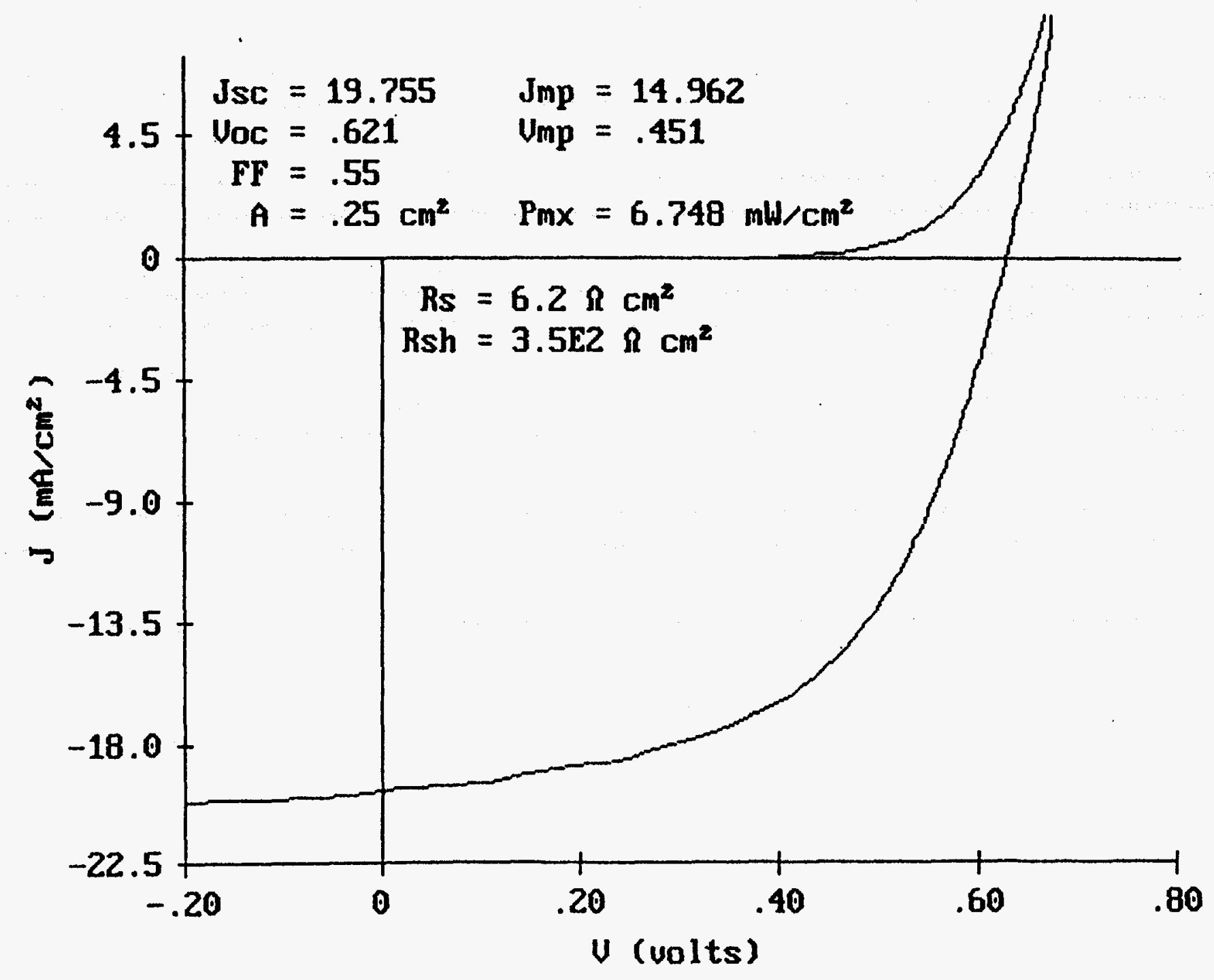


Figure 20: J-V curve of a-si-Ge single-cell measured under filtered blue and red light.

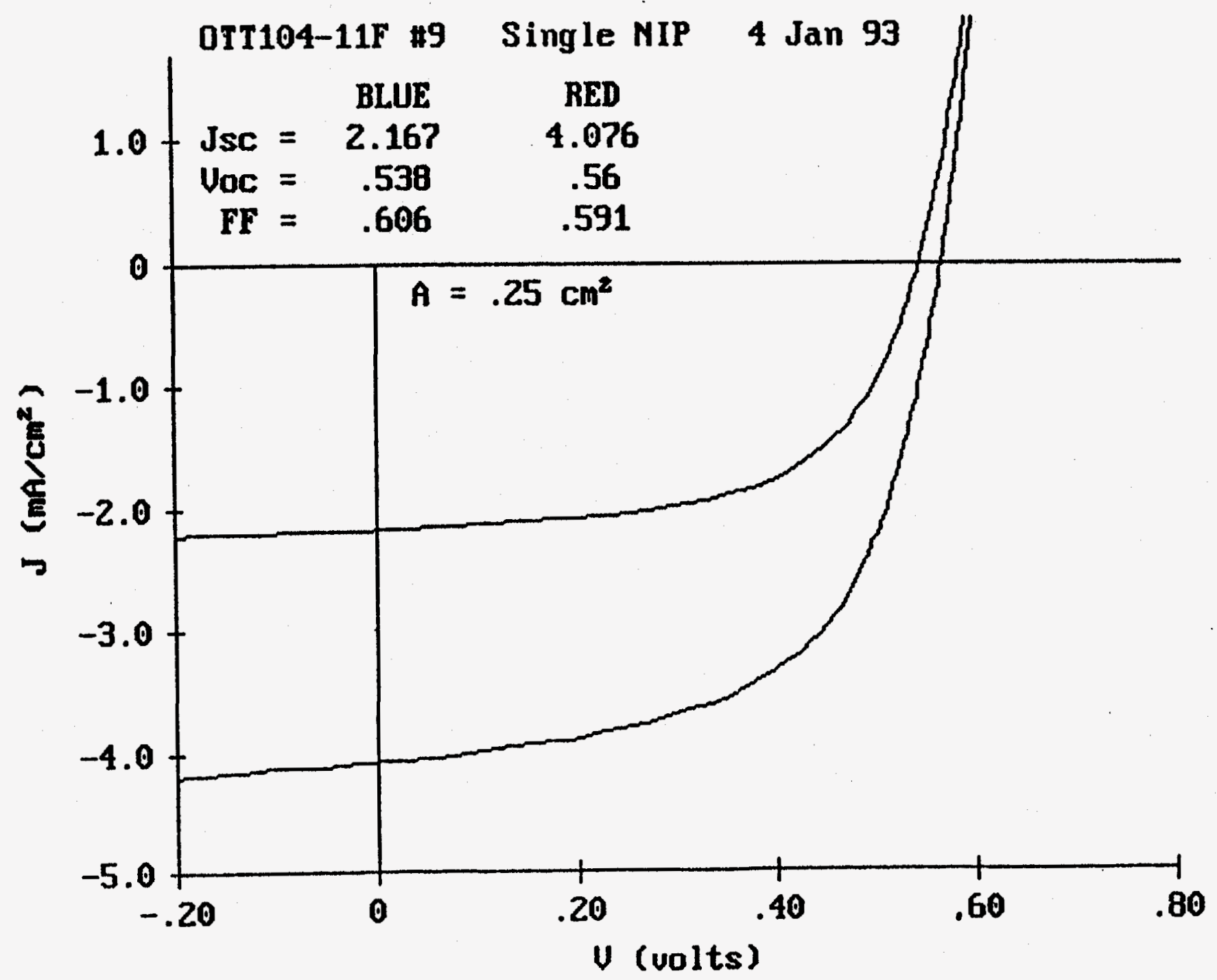


Figure 21: Quantum efficiency curve for a-si-ce single-cell deposited on Ag/Zno back-reflector

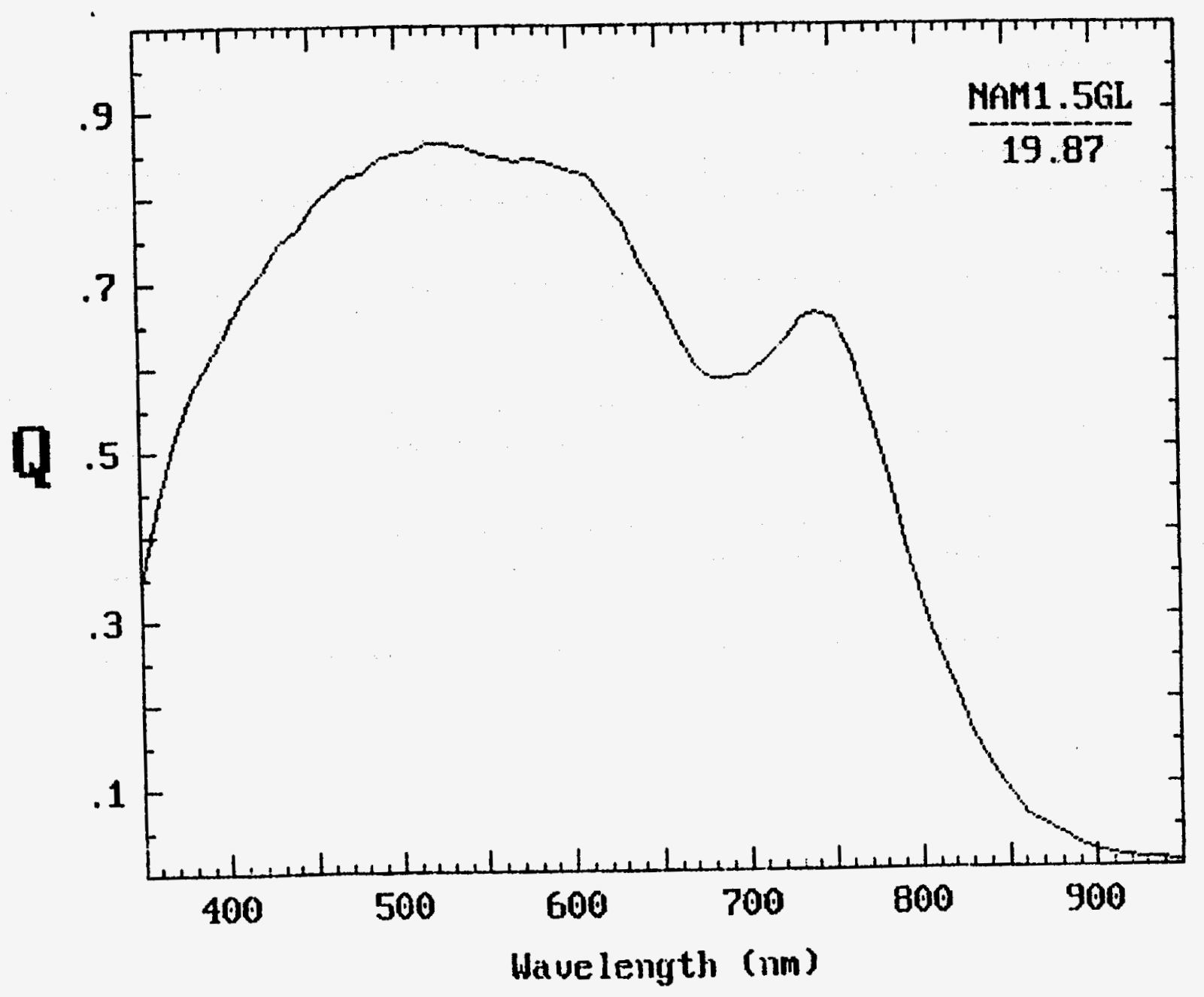


통

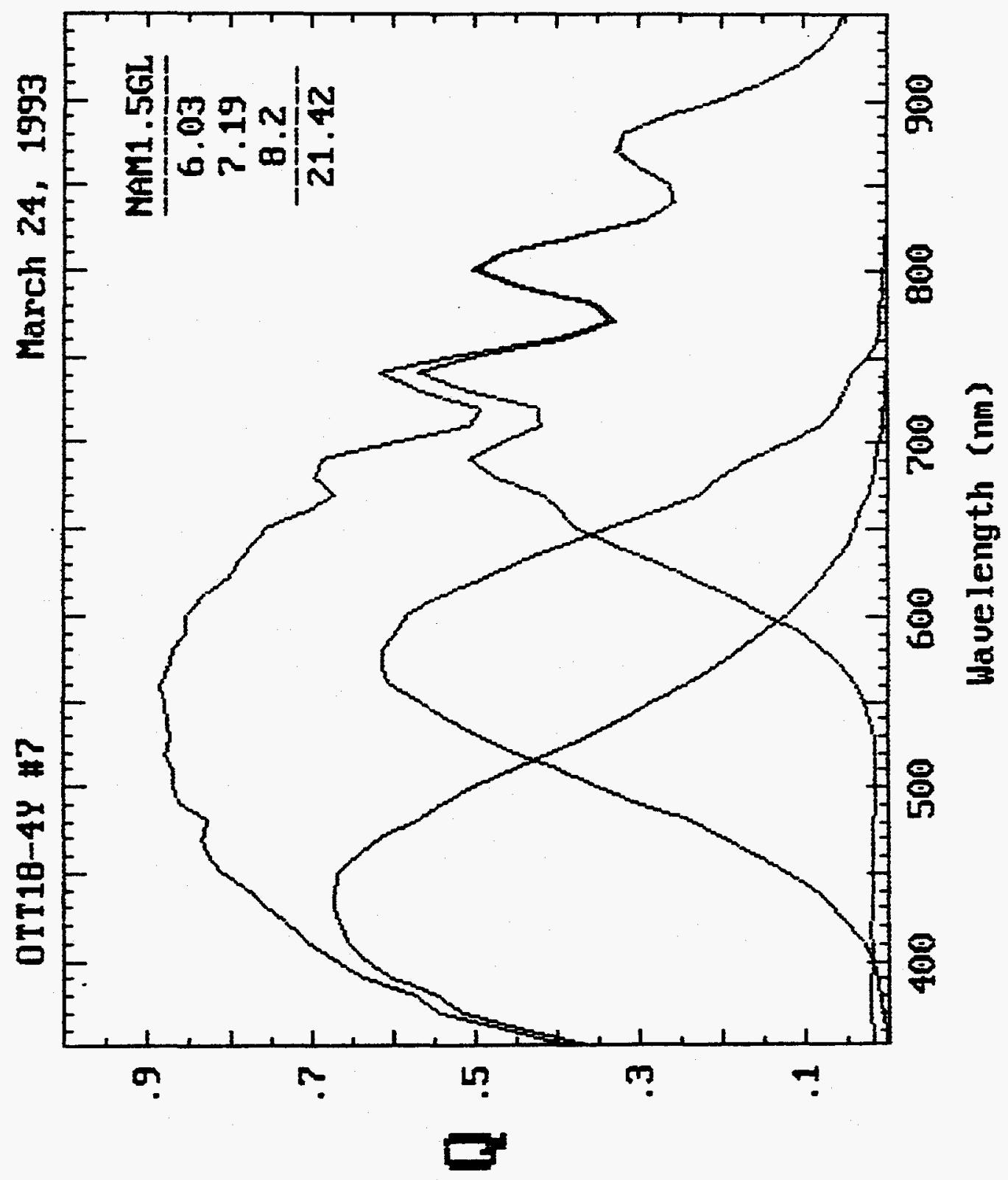

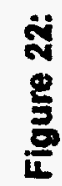




\section{Task 3: Optimization of the Stable Efficiency of Photovoltaic Modules}

\section{Introduction}

In Task 3 the entire process, including substrate washing process, back-reflector deposition, a-Si alloy deposition, transparent conducting oxide deposition, and module assembly, was optimized for the high yield, low cost production of high-efficiency stable modules. The improvements that resulted in Task 1 and Task 2 were incorporated to improve the performance of the solar cell.

\section{Improvement to the continuous roll-to-roll solar cell deposition}

We have systematically investigated the dependence of sub-cell efficiency on the thickness of each layer and current matching. The short circuit current densities of the component cells were, for example, $6.6 \mathrm{~mA} / \mathrm{cm}^{2}, 6.8 \mathrm{~mA} / \mathrm{cm}^{2}$, and $7.2 \mathrm{~mA} / \mathrm{cm}^{2}$ for the top (i3), middle (i2), and the bottom (i1) component cell as we see from the quantum efficiency curve in Figure 17. We explored the effect of different current mismatching conditions on the efficiency by adjusting the thickness of $i 1, i 2$ and $i 3$ layers.

When the i 3 layer was thinner, Jsc decreased. However, the fill-factor increased because the current limiting thin top cell has a higher fill-factor and also mismatched cells give a higher overall fill-factor. In addition, the top-cell limited devices have better stability because the thinner top-cell is more stable. Therefore, we designed the device to be top-cell limited. Since EVAVTefzel encapsulation absorbs some light, we produced the top i layer (i3) slightly thicker to compensate the current loss due to EVATTefzel absorption and still maintain the proper current matching. The il layer was designed to have the highest current since it is the component cell with a relatively low fill-factor.

We also studied and adjusted the deposition conditions of all $\mathrm{n}^{+}$and $\mathrm{p}^{+}$layers to achieve the following:

- proper doping and thickness to maintain high Voc;

- minimum thickness to reduce the absorption. This is especially important for the p3 layer.

- good tunnel junctions between $\mathrm{p} 1$ and $\mathrm{n} 2$ and between $\mathrm{p} 2$ and $\mathrm{n} 3$ layers;

- minimize series resistance.

Each of the nine layers was optimized under the production condition of $1 \mathrm{ft} / \mathrm{min}$. in the continuous roll-to-roll machine shown in Figure 1.

In addition to the optimization of the deposition conditions for each individual layer, we improved process and hardware related aspects in order to improve production yields and consistency.

In the a-Si alloy deposition machine, the thick 2 layer (a-Si intrinsic layer of middle cell) is deposited at high rate, with large amounts of $\mathrm{SiH}_{4}$, at high power and on large cathodes. 
In some of earlier production runs, powder formed on the cathodes toward the end of long runs. We eliminated the problem by changing the hardware to maintain more uniform temperature in the deposition area.

Also, in the i2 chamber, because of the high power, high temperature and lengthy deposition on the large size cathodes, the stainless steel cathode plate sometimes distorted, causing inconsistency over large area substrates. The cathode distortion affects the quality and thickness of i2 layer, in an uncontrolled manner. We split the large cathodes mechanically but still kept good electrical contact between the split cathode. The cathode distortion problem has been eliminated.

In earlier production runs, bearing seizures caused failure in the transport mechanism. To eliminate the problems that we encountered in the substrate transport mechanism, we incorporated an improved mechanical transport system including the newly designed bearings into the back-reflector system, a-Si alloy deposition system and the transparent conductor evaporation system, to ensure reliable operation. As discussed in Task 1 , the improved design effectively prevented mechanical failures such as back-side scratches on the web. These improvements resulted in consistently increased production yields.

In the TCO evaporation machine, the continuous, long time ( -42 hours), high rate, evaporation of metal from the crucibles, occasionally caused the build up of metal at the edge of the crucible, where the temperature was lower. The metal build-up at the crucible edge masks the evaporation path and reduces the uniformity of TCO deposition toward the end of long production runs. We modified the crucible design and eliminated the build-up of metal at the crucible edge.

\section{QAQC process}

QA/QC coupons, 4" long, 14" wide, were uniformly selected from a roll throughout the full production run for quality assurance and quality control (QA/QC). 28 test solar cells of $7.35 \mathrm{~cm}^{2}$ are processed on each coupon by the following procedures:

1) TCO scribing by screen printing of etching paste, heat curing, and rinsing.

2) short and shunt passivation

3) screen printing of Ag paste grid.

Figure 23 is a schematic drawing of a QA/QC coupon, with 28 test cells. We measured the J-V characteristics of cells under AM1.5 Xenon lamp solar simulator. Figure 24 is the $\mathrm{J}-\mathrm{V}$ curve of an $7.35 \mathrm{~cm}^{2}$ cell on a QAVQC coupon. The J-V data of 28 cells in a typical coupon is summarized in Table 2 . From the table, the efficiencies of all 28 cells are above $10 \%$. The uniformity is excellent. With a subcell yield criterion of fill factor $\geq 0.55$, the yield of this coupon is $100 \%$. The average Voc, Jsc, fill factor, and efficiency are, $2.37 \mathrm{~V}$, $6.51 \mathrm{~mA} / \mathrm{cm}^{2}, 0.673$, and $10.41 \%$, respectively, as shown in the table.

To further analyze the performance of solar cells, solar cell samples are taken after the aSi alloy deposition machine, before the web is loaded into the roll-to-roll TCO machine and evaluated by evaporating small area ITO and Ag grid in batch evaporation systems. Figure 25 is a $\mathrm{J}-\mathrm{V}$ characteristic of a $0.25 \mathrm{~cm}^{2}$ triple-junction two band-gap solar cell produced in our continuous roll-to-roll a-Si alloy deposition machine in a $2500 \mathrm{ft}$. production run with improved process conditions. As is seen in Figure 25, 11.1\% initial 
Figure 23: $\quad$ Schematic drawing of a QNQC coupon with 28 sub-celts $\left(7.35 \mathrm{~cm}^{2}\right.$ active area)

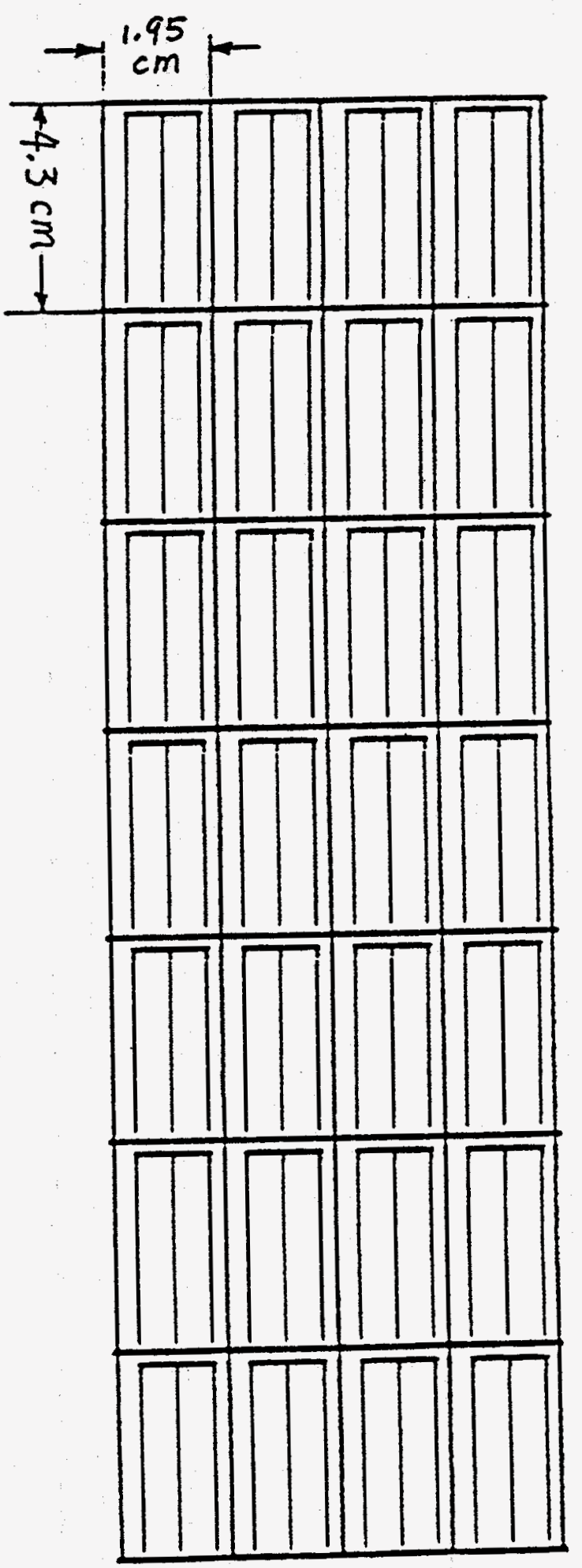


Figure 24: J-V curve of a $7.36 \mathrm{~cm}^{2}$ triple-junction sub-cell

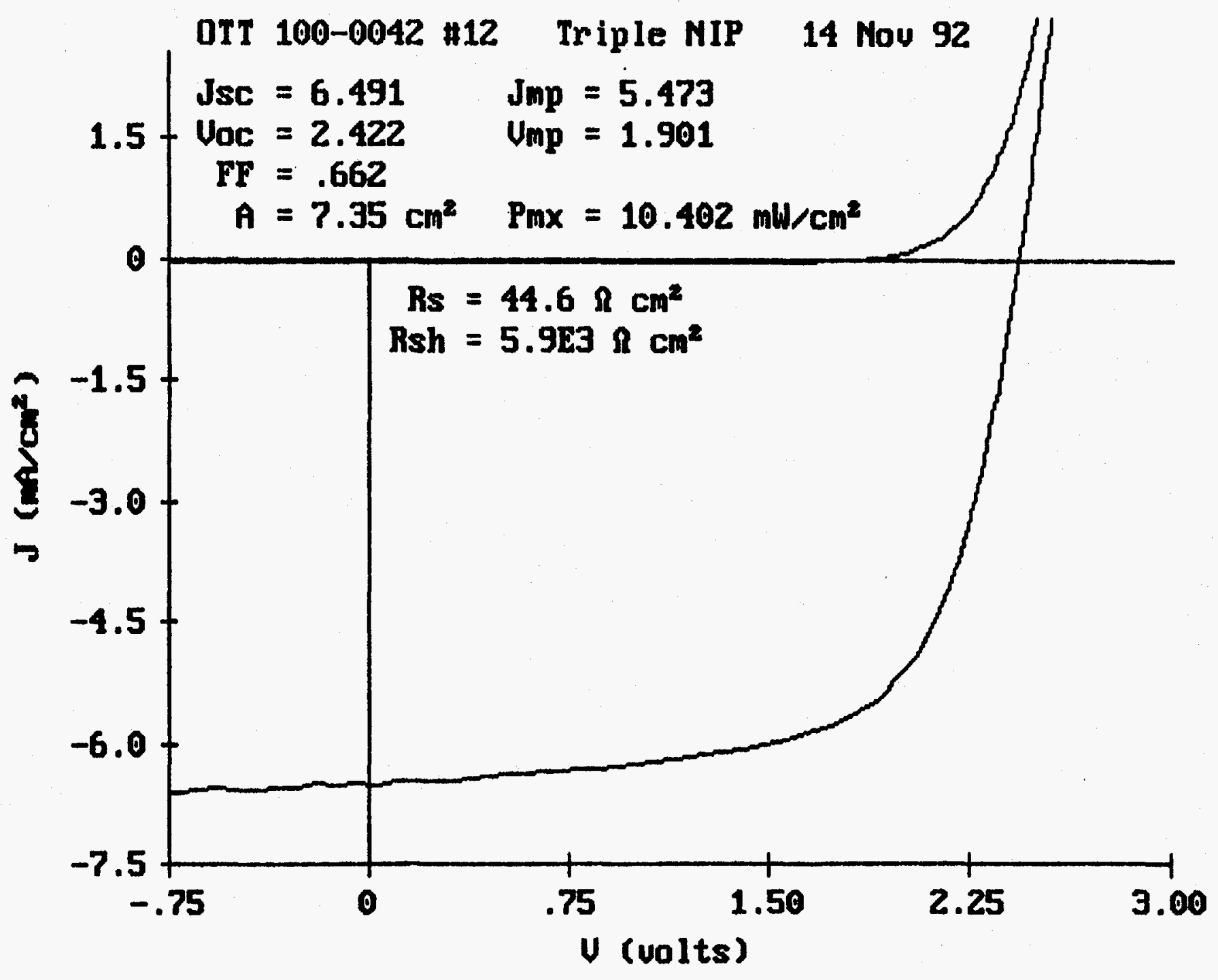




$1 p \max =10.49$
$2 p \max =10.64$
$3 p \max =10.37$
$4 p \max =10.46$
$5 p \max =10.59$
$6 p \max =10.52$
$7 p \max =10.36$
$8 p \max =10.19$
$9 p \max =10.39$
$10 p \max =10.30$
$11 p \max =10.31$
$12 p \max =10.36$
$13 p \max =10.45$
$14 p \max =10.72$
$15 p \max =10.36$
$16 p \max =10.20$
$17 p \max =10.54$
$18 p \max =10.39$
$19 p \max =10.33$
$20 p \max =10.40$
$21 p \max =10.50$
$22 p \max =10.39$
$23 p \max =10.47$
$24 p \max =10.59$
$25 p \max =10.50$
$26 p \max =10.30$
$27 p \max =10.34$
$28 p \max =10.21$

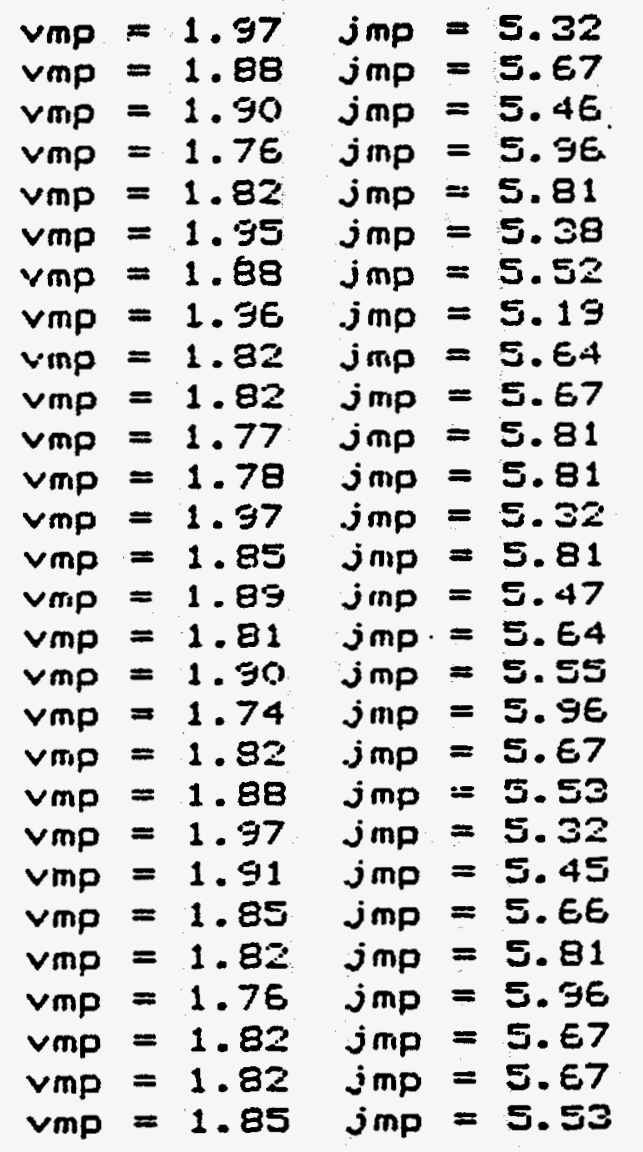

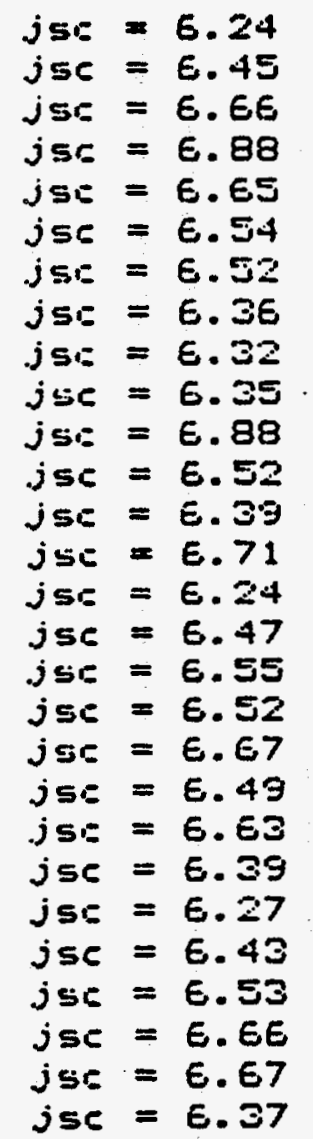

Vac 2.39

vou $=2.38$
vou $=2.39$
vou $=2.37$
vou $=2.37$
vou $=2.37$
vac $=2.38$
vou $=2.38$
vou $=2.33$
vou $=2.38$
vou $=2.37$
vou $=2.37$
vou $=2.37$
vou $=2.35$
vou $=2.39$
vou $=2.38$
vou $=2.38$
vou $=2.37$
voc $=2.37$
vou $=2.37$
vou $=2.38$
vou $=2.39$
voc $=2.38$
vou $=2.37$
vac $=2.37$
vou $=2.37$
vou $=2.37$
vou $=2.38$
vac $=2.38$

Jse 6.71
$F F=0.70 .6$

$F F=0.694$

$F F=0.658$

$F F=0.642$

$F F=0.673$

$F F=0.67 \epsilon$

$F F=0.6 \in 8$

$F F=0.670$

$F F=0.684$

$F F=0 . E B \epsilon$

$F F=0.633$

$F F=0.571$

$F F=0.688$

$F F=0.6 .69$

$F F=0.698$

$F F=0 . E E 3$

$F F=0.679$

$F F=0.672$

$F F=0.654$

$F F=0 . E 74$

$F F=0 . E \in 3$

$F F=0.684$

$F F=0.704$

$F F=0.695$

$F F=0.679$

$F F=0 . E 52$

$F F=0.651$

$F F=0.674$

Eest Cell \#14

Fimax 10.71 Eff(\%) 10.71

Cell area $=7.35 \mathrm{~cm}^{\wedge} 2$

FOR CELLS WITH FF > 0.55

Yield $100 \%$ Voc (avg) 2.37 Jse(avg) $E .51$ Fm (avg) 10.41 FF(avg) .673.

Sigma( $v)$ Sigma(i) .1E Sigma(p) .13

Sigma(ff) .01 


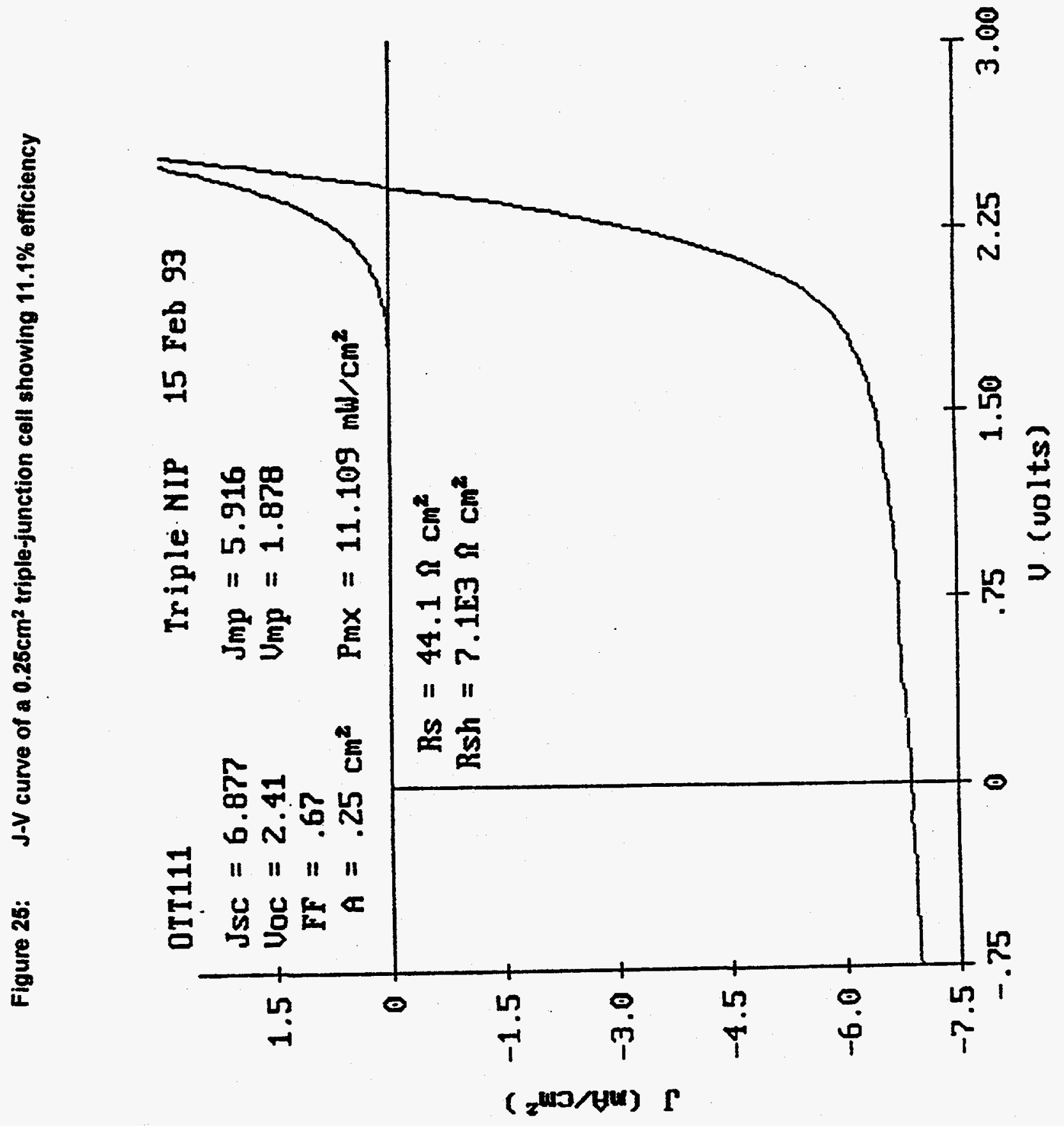


efficiency was achieved in the a-Si alloy solar cell production machine under production conditions. Figure 26 is the quantum efficiency curve of the $11.1 \%$ cell shown in Figure 25 .

\section{A typical 2500 feet (19 kW) production run}

As described previously, ECD's PV production process consists of operation through continuous roll-to-roll machines of web washing, back-reflector deposition, a-Si alloy deposition, and TCO deposition, followed by module assembly. $\mathrm{Ag} / \mathrm{ZnO}$ back-reflector, aSi alloys, and TCO are sequentially deposited on stainless steel of 5 mil. thick, 14 in. wide, and $2500 \mathrm{ft}$. long, at a speed of $1 \mathrm{ft} / \mathrm{min}$. A typical $2500 \mathrm{ft}$. roll is finished within 42 hours. During operation all of the process parameters are controlled, monitored, and recorded through the use of $\mathrm{PC}$ computerized data acquisition and process controlling systems.

Out of the total web width of $14 ", 12.5^{\prime \prime}$ is used as the active area in the final module assembly. With a yield of $99 \%$ and stable module efficiency of $8 \%$, a $2500 \mathrm{ft}$. run produces an output of 19.2 kilowatt.

In Table 3, we summarize the average I-V data of QA/QC coupons throughout an entire production run. A QA/QC coupon has 28 cells and the average was calculated on 28 cells. In each line of this table, we list average Voc, Jsc, fill factor, and efficiency as well as the yield of a coupon taken at the corresponding slab number. Detailed I-V data for each cell of coupon 1050.2 at meter mark $417 \mathrm{~m}$ was shown previously in Table 2 . Over the entire run, the average efficiency is $10.21 \%$ with a standard deviation of $0.02 \%$. The average subcell yield for this production run is $99.7 \%$.

Figure 27 is a three dimensional plot of cell efficiency for all cells in this run. Figure 27 shows the efficiency data for 1176 individual cells for the entire production run as a function of the position of sub-cells in the $2500 \mathrm{ft}$. long, $14 \mathrm{in}$. wide substrate. Out of 1176 cells plotted in the figure, only three cells failed. Figure 28 through Figure 30 show the three dimensional plot of Voc, Jsc, and fill factor, respectively. The solar cell performances are highly uniform throughout the entire run. Production parameters recorded in the computerized data acquisition system showed excellent consistency and uniformity achieved in our continuous roll-to-roll manufacturing process.

\section{Module Assembly}

Strip cells are produced by processing slabs of solar cell material through TCO scribing, short and shunt passivation and screen printing of Ag paste grid pattern. A strip cell is a single solar cell with an aperture of 12.5" $\times 5.4^{\prime \prime}$. After cutting, trimming and bus bar installing, nine strip cells are connected together in series, as a module. A diode is connected in parallel with every strip to prevent the strip cell from being reverse biased. The module is then vacuum laminated, in a high temperature oven, with Tefzel, EVA and crane glass as the transparent front cover and with layers of EVA, crane glass, nylon, and thin metal backing plate as the back cover. An aluminum frame and junction box are installed to finish the module. Figure 31 is a schematic drawing of ECD's $1 \mathrm{ft} \times 4 \mathrm{ft}$ a-Si alloy production PV module. 
Figure 26: Quantum efficiency curve for the $0.25 \mathrm{~cm}^{2}$ triple-junction cell showing $11.1 \%$ efficiency

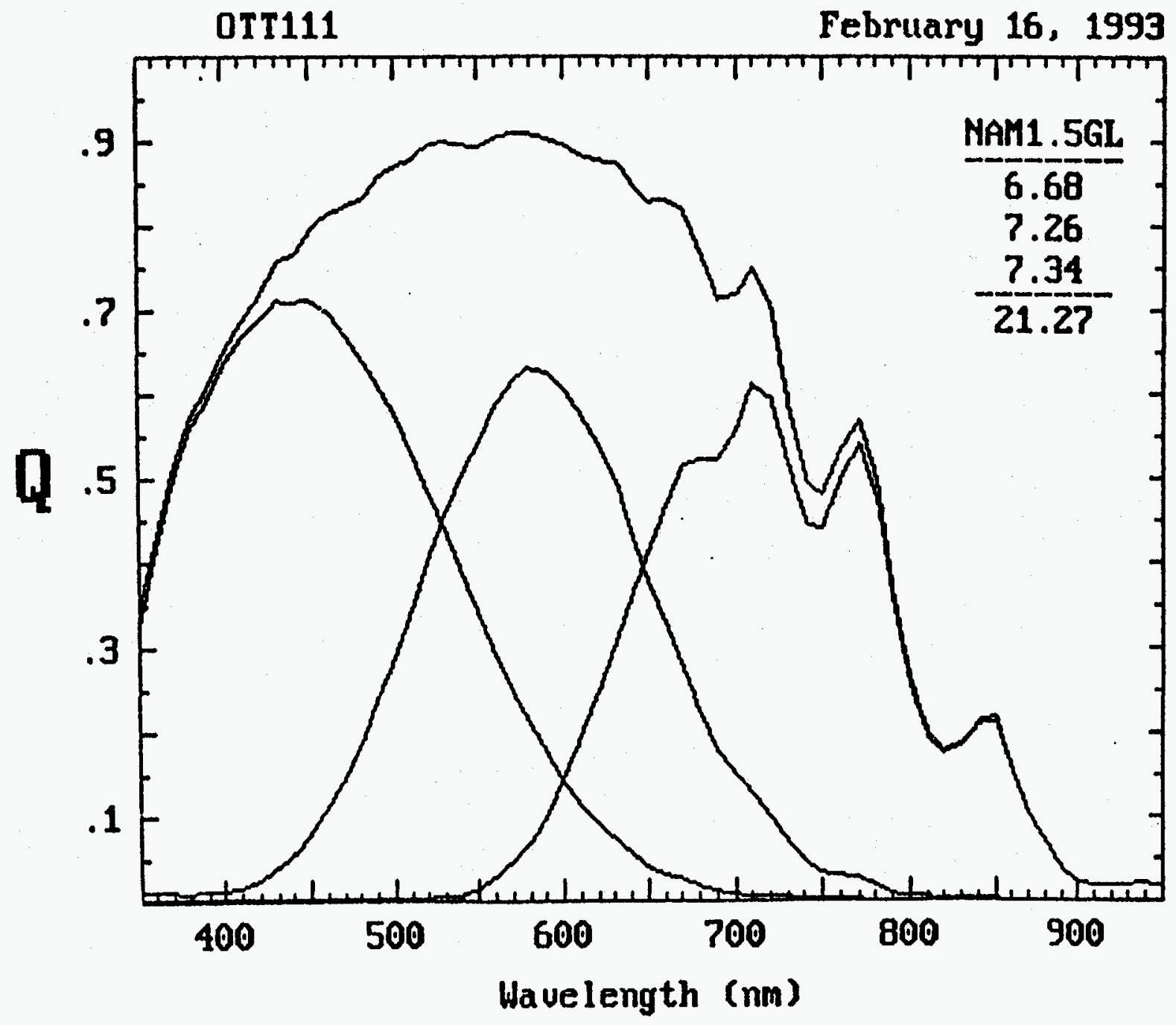


Table 3: $\quad$ Average cell performance data of coupons throughout an entire run.

\begin{tabular}{|c|c|c|c|c|c|c|}
\hline Slab" & $\begin{array}{l}\text { Meter Mark } \\
\text { (m) }\end{array}$ & $\begin{array}{l}V_{0 c} \\
M\end{array}$ & $\begin{array}{c}\text { Jse } \\
\text { (mNem2) }\end{array}$ & $F F$ & $\begin{array}{l}\text { Efficiency } \\
(\%)\end{array}$ & $\begin{array}{l}\text { Yield } \\
(\%)\end{array}$ \\
\hline 53.1 & 0 & 2.36 & 6.46 & 0.659 & 10.06 & 96 \\
\hline 532 & 0 & 2.37 & 6.47 & 0.658 & 10.1 & 100 \\
\hline 73.1 & 8 & 2.34 & 6.5 & 0.654 & 9.98 & 100 \\
\hline 732 & 8 & 2.36 & 6.5 & 0.659 & 10.15 & 96 \\
\hline 84.1 & 13 & 2.37 & 6.3 & 0.669 & 10 & 100 \\
\hline 842 & 13 & 2.36 & 6.33 & 0.667 & 10 & 100 \\
\hline 94.1 & 17 & 2.36 & 6.64 & 0.642 & 10.06 & 96 \\
\hline 942 & 17 & 2.37 & 6.6 & 0.648 & 10.16 & 93 \\
\hline 109.1 & 24 & 2.36 & 6.48 & 0.643 & 9.85 & 100 \\
\hline 1092 & 24 & 2.37 & 6.48 & 0.646 & 9.92 & 100 \\
\hline 137.1 & 35 & 2.38 & 6.53 & 0.653 & 10.14 & 100 \\
\hline 1372 & 35 & 2.38 & 6.44 & 0.656 & 10.05 & 100 \\
\hline 150 & 41 & 2.35 & 6.52 & 0.661 & 10.15 & 100 \\
\hline 200 & 62 & 2.35 & 6.64 & 0.658 & 1029 & 100 \\
\hline 2002 & 62 & 2.36 & 6.53 & 0.67 & 10.35 & 100 \\
\hline 250 & 82 & 2.35 & 6.61 & 0.655 & 102 & 100 \\
\hline 300 & 103 & 2.35 & 6.55 & 0.655 & 10.12 & 100 \\
\hline 350 & 124 & 2.35 & 6.43 & 0.666 & 10.08 & 100 \\
\hline 450 & 166 & 2.35 & 6.51 & 0.659 & 10.1 & 100 \\
\hline 4502 & 166 & 2.36 & 6.54 & 0.669 & 10.37 & 100 \\
\hline 500 & 187 & 2.35 & 6.55 & 0.659 & 10.16 & 100 \\
\hline 550 & 208 & 2.38 & 6.47 & 0.654 & 10.07 & 96 \\
\hline 600 & 229 & 2.36 & 6.49 & 0.662 & 10.14 & 96 \\
\hline 650 & 250 & 2.36 & 6.33 & 0.666 & 9.97 & 100 \\
\hline 700 & 271 & 2.36 & 6.46 & 0.667 & 10.2 & 96 \\
\hline 7002 & 271 & 2.37 & 6.41 & 0.671 & 10.19 & 100 \\
\hline 750 & 292 & 2.39 & 6.4 & 0.661 & 10.14 & 100 \\
\hline 800 & 312 & 2.36 & 6.59 & 0.658 & 10.25 & 100 \\
\hline 850 & 334 & 2.35 & 6.56 & 0.662 & 1024 & 100 \\
\hline 900 & 354 & 2.35 & 6.42 & 0.664 & 10.05 & 100 \\
\hline 950 & 375 & 2.35 & 6.54 & 0.662 & 1022 & 100 \\
\hline 9502 & 375 & 2.37 & 6.48 & 0.669 & 1029 & 100 \\
\hline 10002 & 396 & 2.37 & 6.54 & 0.667 & 10.36 & 100 \\
\hline 1000.3 & 396 & 2.37 & 6.45 & 0.676 & 10.36 & 100 \\
\hline 10502 & 417 & 237 & 6.51 & 0.673 & 10.41 & 100 \\
\hline 1050.3 & 417 & 2.37 & 6.56 & 0.671 & 10.45 & 100 \\
\hline 11002 & 438 & 2.37 & 6.44 & 0.667 & 102 & 100 \\
\hline 1100.3 & 438 & 2.37 & 6.52 & 0.665 & 10.29 & 100 \\
\hline 11502 & 459 & 2.37 & 6.39 & 0.68 & 10.33 & 100 \\
\hline 1150.3 & 459 & 2.37 & 6.43 & 0.671 & 1026 & 100 \\
\hline 12002 & 480 & 2.37 & 6.46 & 0.675 & 10.36 & 100 \\
\hline 1200.3 & 480 & 2.37 & 6.45 & 0.673 & 10.31 & 100 \\
\hline 12502 & 501 & 2.37 & 6.43 & 0.674 & 10.3 & 100 \\
\hline 1250.3 & 501 & 2.37 & 6.47 & 0.667 & 1025 & 100 \\
\hline 13002 & 522 & 2.37 & 6.32 & 0.68 & 1023 & 100 \\
\hline 1300.3 & 522 & 2.37 & 6.45 & 0.671 & 10.26 & 100 \\
\hline 13502 & 543 & 2.37 & 6.39 & 0.68 & 10.34 & 100 \\
\hline
\end{tabular}


Table 3: Average cell performance data of coupons throughout an entire run. continued

$\begin{array}{lcccccc}\text { Slab" } & \begin{array}{c}\text { Meter Mark } \\ (\mathrm{m})\end{array} & \begin{array}{c}\text { Voc } \\ \text { M }\end{array} & \begin{array}{c}\text { Jse } \\ \text { (mAcm2) }\end{array} & \text { FF } & \begin{array}{c}\text { Etficiency } \\ (\%)\end{array} & \begin{array}{c}\text { Yield } \\ (\%)\end{array} \\ 1350.3 & 543 & 2.37 & 6.48 & 0.67 & 10.32 & 100 \\ 14002 & 564 & 2.38 & 6.34 & 0.67 & 10.15 & 100 \\ 1400.3 & 564 & 2.38 & 6.32 & 0.669 & 10.1 & 100 \\ 1450.2 & 585 & 2.38 & 6.35 & 0.674 & 102 & 100 \\ 1450.3 & 585 & 2.38 & 6.29 & 0.679 & 10.19 & 100 \\ 1475.2 & 595 & 2.38 & 6.32 & 0.671 & 10.12 & 100 \\ 1475.3 & 595 & 2.38 & 6.4 & 0.673 & 10.29 & 100 \\ & & & & & & \\ \text { Average } & & 2.366 & 6.46 & 0.668 & 10.214 & 99.74 \\ \text { Std. Devietion } & 0.0017 & 0.013 & 0.0011 & 0.017 & 0.2\end{array}$

Notes

1) The first $35 \mathrm{~m}$ of this run (slab 53 to 137 ) was used for experiments with different deposition conditions

2) The rest of the run $(36 \mathrm{~m}$ to $600 \mathrm{~m})$ are deposited with the same deposition conditions

3) Averages and standard deviations are calculated for slabs between 150 and 1475

4) Coupons with (1) were measured when temperature was slightly higher 


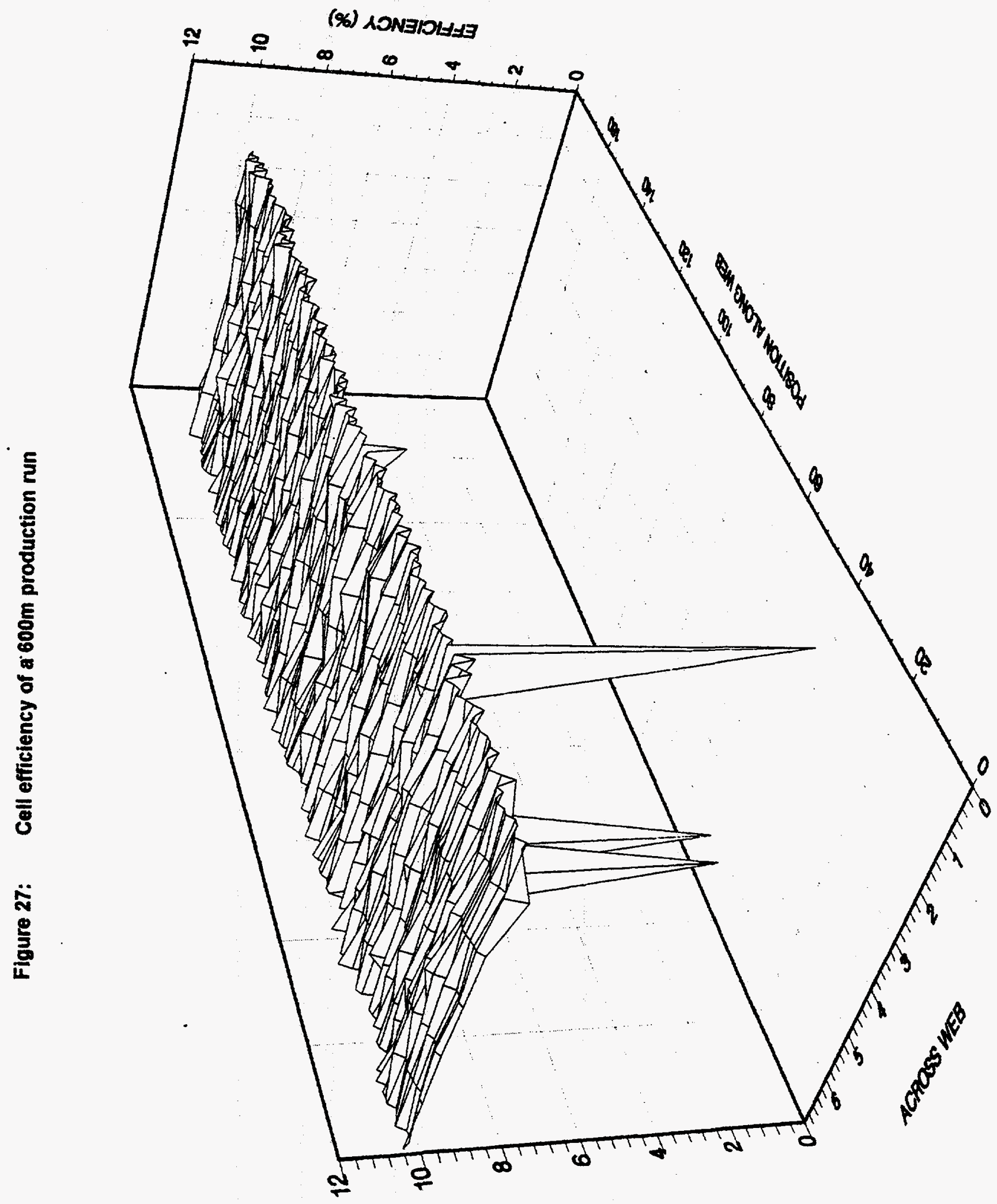




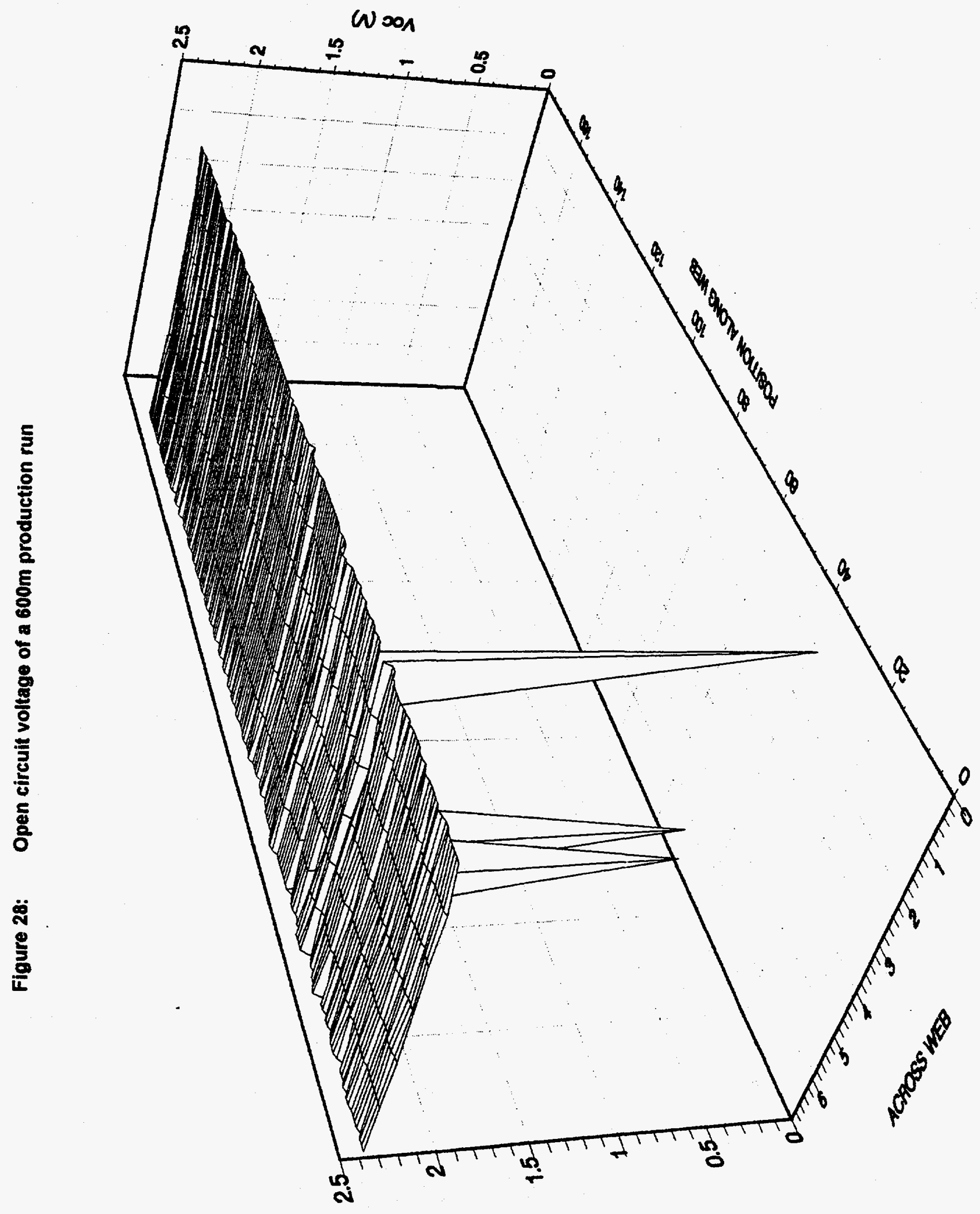




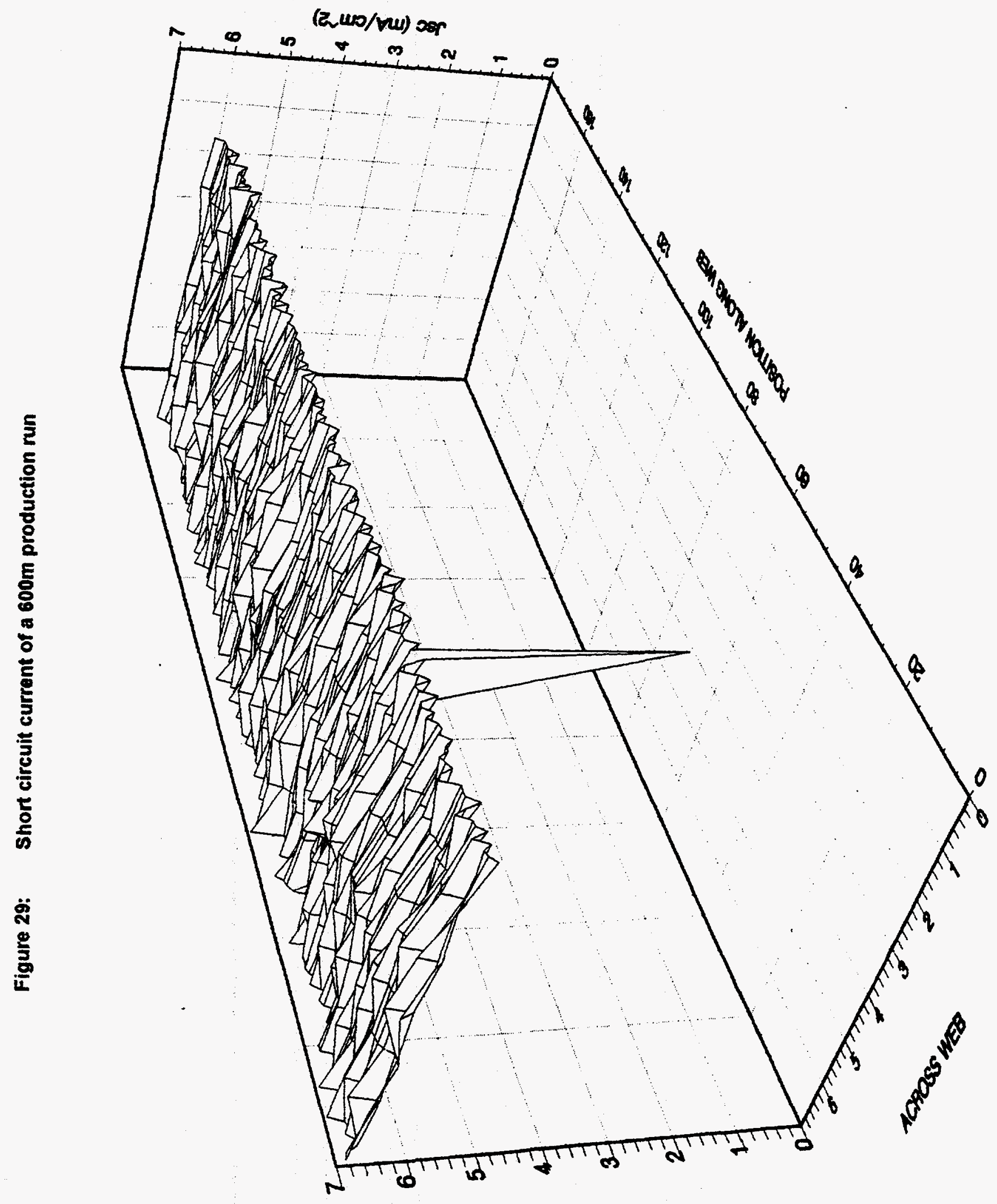


Figure 30: Fill factor of a $600 \mathrm{~m}$ production run

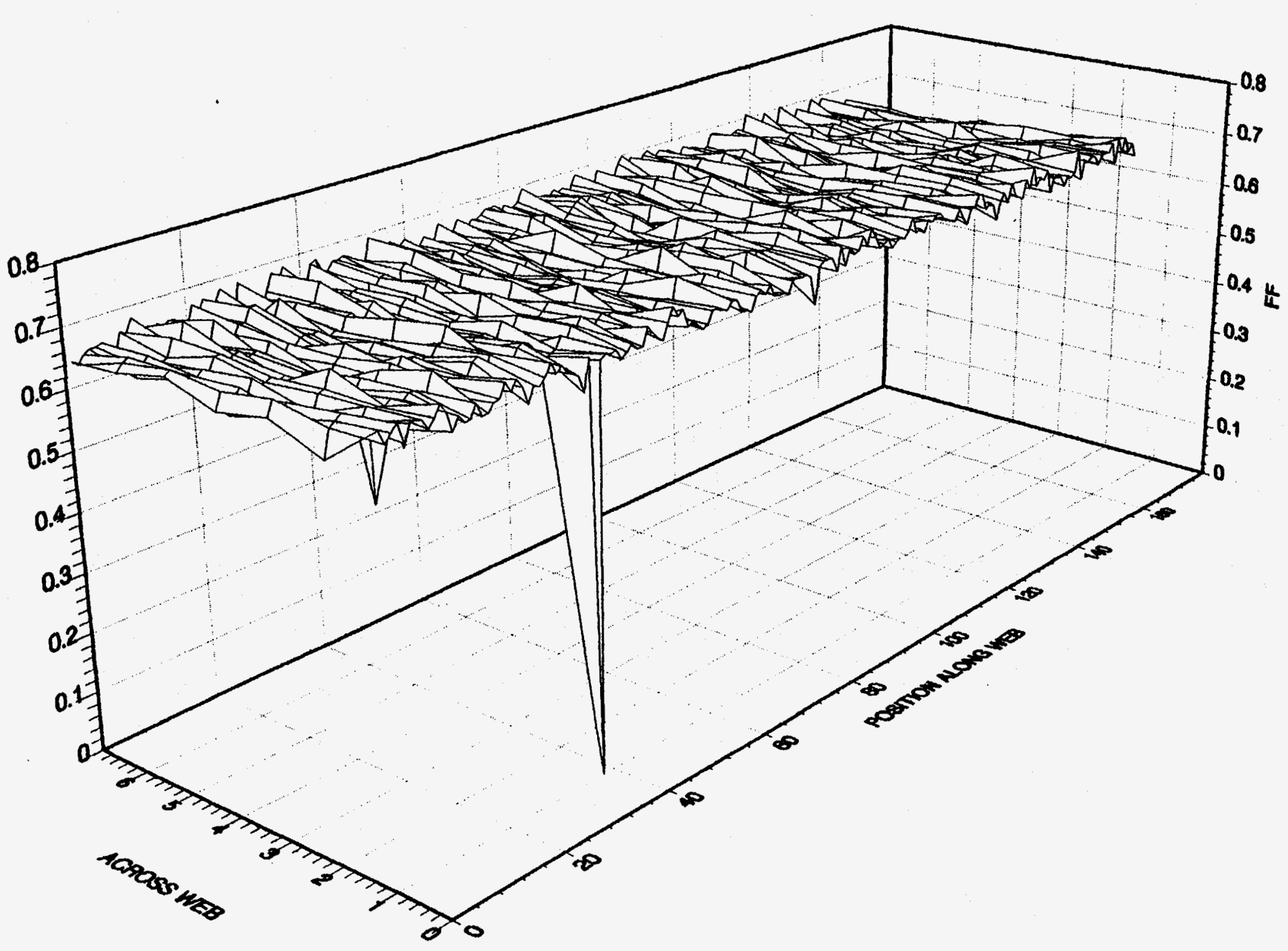


Figure 31: A schematic drawing of 1ft. $x$ 4ft. module

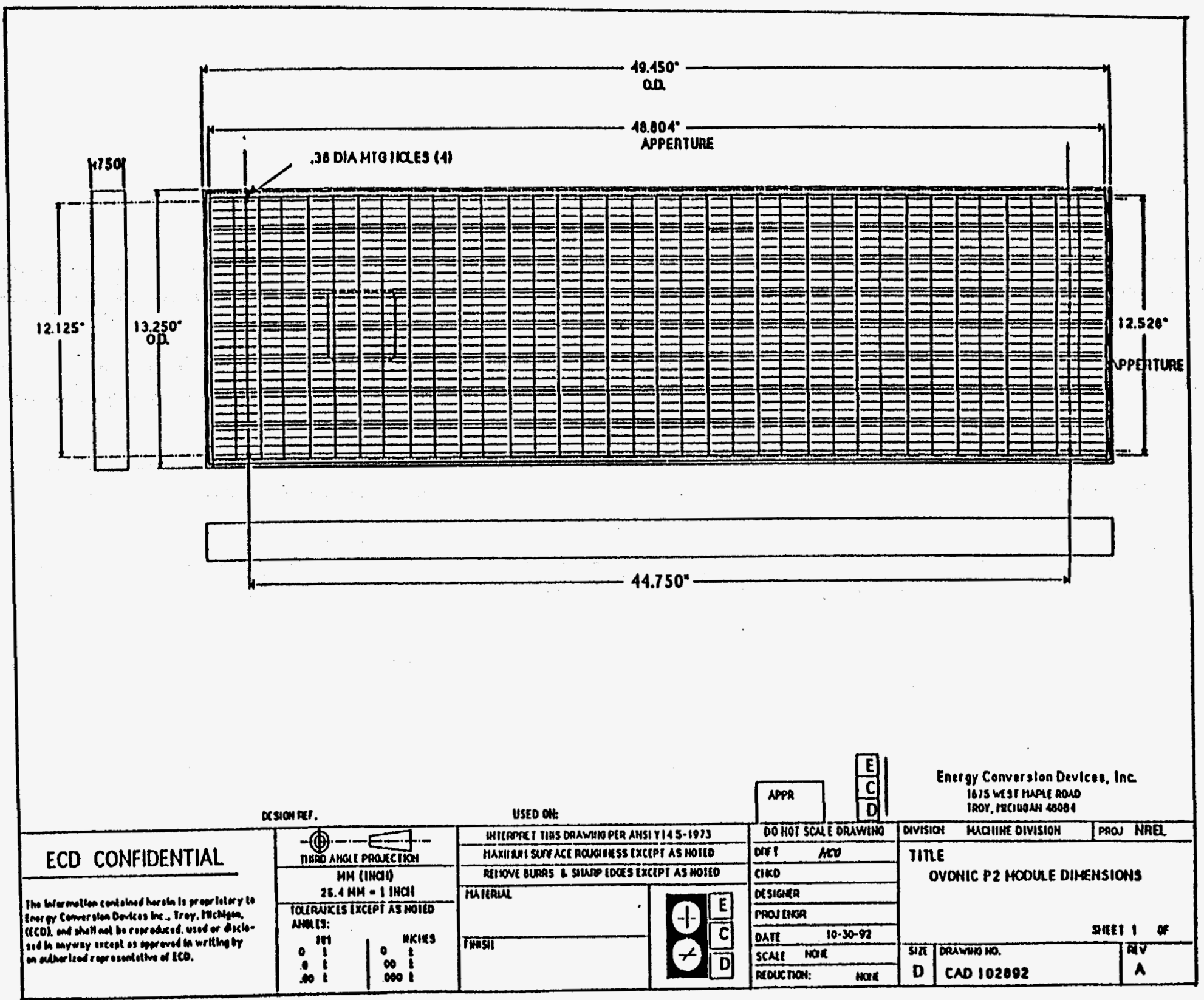




\section{Improvements in module design to reduce losses}

To further improve the module efficiency, we investigated the losses from the module fabrication and assembly process. The loss in module efficiency is due to the following three factors:

- coverage losses due to TCO etching line, grid line, and bus bars

- electrical losses due to the resistivity of the TCO, grids and bus bars

- current loss due to encapsulation.

We quantitatively investigated the losses by computer modeling. We assume the following parameters:

$\begin{array}{ll}\text { power density } & 10 \mathrm{~mW} / \mathrm{cm}^{2} \\ \text { operating voltage } & 1.8 \text { volts } \\ \text { resistivity of Ag paste grid } & 17 \mathrm{~m} / \text { square (measured). } \\ \text { TCO resistivity } & 100[/ \text { square. }\end{array}$

We calculated and found the total losses to be $17 \%$.

To minimize the losses, the etching line, grid, and bus bar pattern have been redesigned. Figure 32 is a schematic drawing of a new strip cell artwork design. The dimensions of the etch line, grids and bus bars are listed in Table 4. Using the parameters described above, we calculated the losses in each area as shown in Table 4, listed under theoretical. The total loss of the improved design is calculated to be $12.34 \%$. Strip cells were produced with the improved design and the dimensions of the etch line, grid line and bus bars were measured. The total loss for the improved design was estimated to be $13.4 \%$. This is in agreement with our actual loss in our production module assembly process.

\section{ECD's high efficiency $4 \mathrm{ft}^{2}$ production module}

$4 \mathrm{ft}^{2}$ modules were assembled using triple-junction two band-gap solar cells produced in a continuous roll-to-roll manufacturing line. Figure 33 is the I-V curve of a $4 \mathrm{ft}^{2}$ module measured with a Spire solar simulator. The initial aperture module efficiency is $9.5 \%$ and the total power output is $37.18 \mathrm{~W}$ for a module of $3923 \mathrm{~cm}^{2}$ aperture area. This efficiency is higher than any reported efficiency for a-Si alloy production modules.

\section{Stable efficiency of modules}

To measure the stable efficiency of our modules, light soaking stability tests were carried out. Philip's metal halide 1000/U light bulbs, powered by appropriate ballasts were used. The light intensity is measured with a Silicon detector filtered with a heat filter so that the quantum efficiency of the detector is close to that of an a-Si alloy solar cell. The light intensity inside the $4 \mathrm{ft}^{2}$ module area is within $20 \%$ from $100 \mathrm{~mW} / \mathrm{cm}^{2}$ with the average at $100 \mathrm{~mW} / \mathrm{cm}^{2}$. Temperature of the module under light soaking was around $50^{\circ} \mathrm{C}$. The temperature was slightly higher at the center of the module where the light intensity is about $20 \%$ higher than $100 \mathrm{~mW} / \mathrm{cm}^{2}$. Each module was degraded with a load such that it 


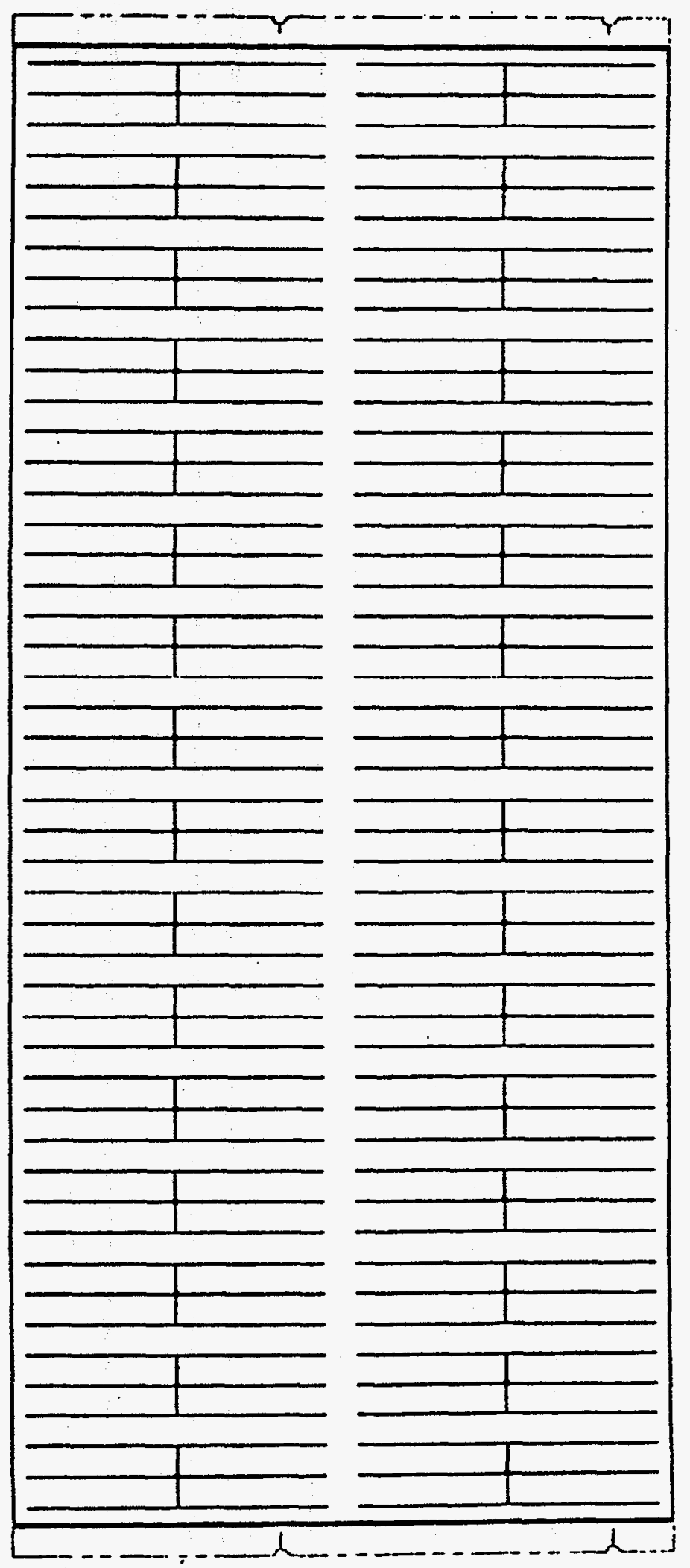


Table 4: Grid/bus bar/encapsulation losses Theoretical vs. actual

Current Module Design

A Module $=9$ strips

2 Wire Bus Bar per strip

Wire Bus Bar is connected on both sides.

Theoretical

$\underline{\text { Real }}$

Grid Width

Bus Bar Width

$0.2 \mathrm{~mm}$

$0.28 \mathrm{~mm}$

ITO Width

$0.4 \mathrm{~mm}$

$0.5 \mathrm{~mm}$

Length of Grid

$0.64 \mathrm{~cm}$

$0.64 \mathrm{~cm}$

Width of Intra-Strip Etch Line

$3.3 \mathrm{~cm}$

$3.1 \mathrm{~cm}$

Width of Inter-Strip Etch Line

0

0

$0.75 \mathrm{~mm}$

$0.55 \mathrm{~mm}$

1. Estimated Losses

Theoretical

Real

Losses =

ITO Electrical Loss

$1.0 \%$

$1 \%$

Grid Electrical Loss

$0.59 \%$

$2.3 \%$

Grid Shadow Loss

$2.98 \%$

$3.8 \%$

Silver Wire Bus Shadow

$0.59 \%$

$0.74 \%$

Etch Loss (Coverage)

$0.99 \%$

$1 \%$

Protruding Pads

$1.0 \%$

$.37 \%$

Main Bus Bar Electrical

$0.19 \%$

$.19 \%$

Encapsulation

$4 \%$

$3 \%$

Subcell Mismatch

$1 \%$

$1 \%$

Total

$12.34 \%$

$\uparrow 3.4 \%$

2. Cell to Module Actual Loss.

Small area cell efficiency (Ag silver paste grided, average)

$10.9 \%$

$4 \mathrm{Ft}$. Sq. Encapsulated Module

Efficiency

Loss

$9.5 \%$

$13 \%$ 


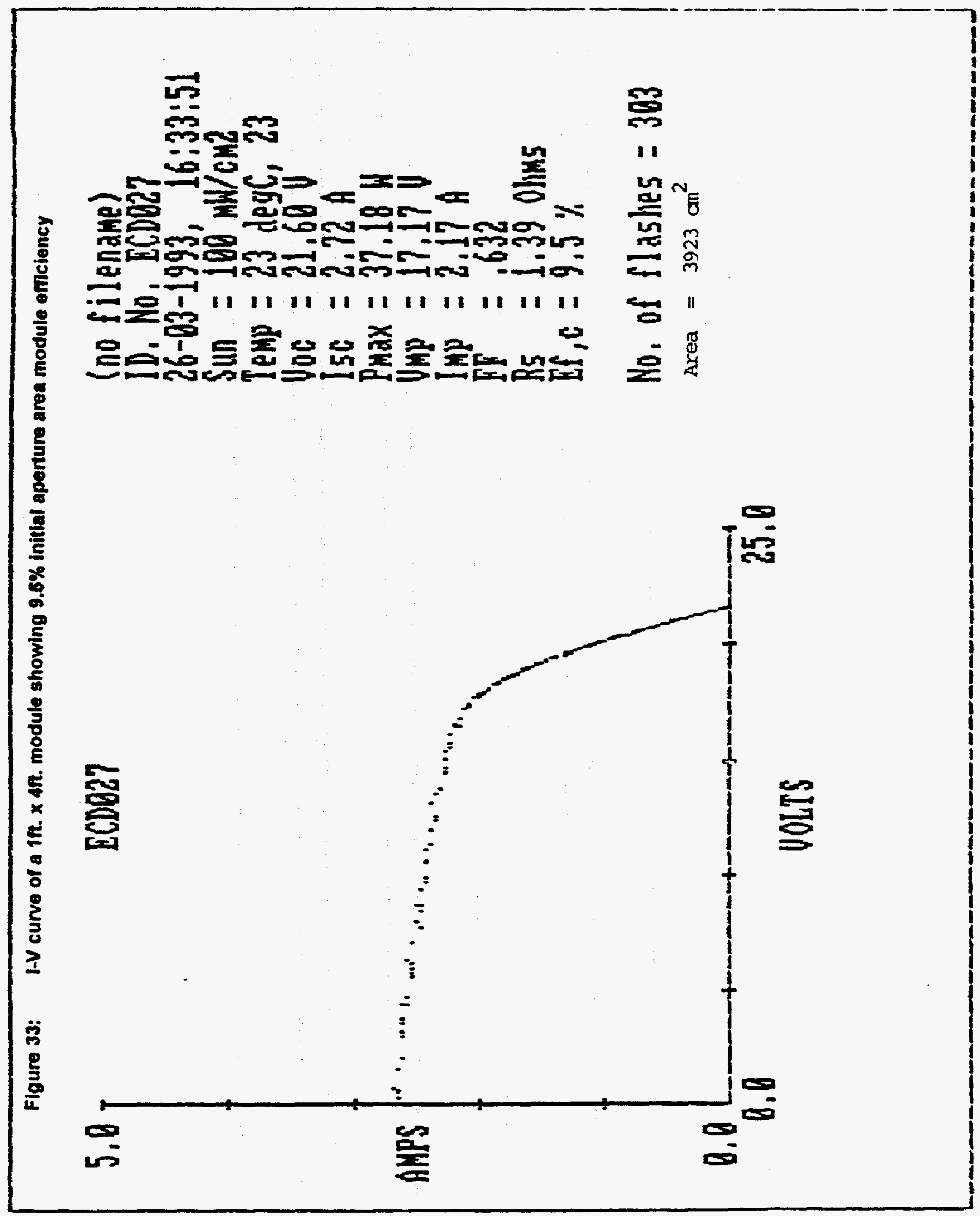


Table 5: Light soaking test data of two $1 \mathrm{ft} \times 4 \mathrm{ft}$ triple-junction modules (Module 27 and Module 20).

Metal halide lamp was used for light-soaking. AC powered light was used and the intensity oscillated between $60 \mathrm{~mW} / \mathrm{cm}^{2}$ to $150 \mathrm{~mW} / \mathrm{cm}^{2}$ at $60 \mathrm{~Hz}$. The surface temperature of the module was approximately $50^{\circ} \mathrm{C} \sim 60^{\circ} \mathrm{C}$. Higher temperature was observed where the light intensity was higher than the average of $100 \mathrm{~mW} / \mathrm{cm}^{2}$. Aperture area $=3923 \mathrm{~cm}^{2}$. Aperture area of Module 028 after framing is $3907 \mathrm{~cm}^{2}$.

\begin{tabular}{|c|c|c|c|c|c|c|c|}
\hline Module \# & Light Soaking & Voc & Isc & FF & Pmax & Efficiency & Drop in \\
\hline & Time (Hrs) & (V) & $(\mathrm{A})$ & & $(\mathrm{W})$ & $(\%)$ & Eff. (\%) \\
\hline & O(Initial) & 21.30 & 2.75 & 0.634 & 37.15 & 9.5 & \\
\hline \#028 & 72 & 20.94 & 2.67 & 0.580 & 32.37 & 8.3 & 13 \\
\hline & 230 & 21.05 & 2.64 & 0.571 & 31.72 & 8.1 & 15 \\
\hline & 393 & 20.97 & 2.63 & 0.573 & 31.58 & 8.1 & 15 \\
\hline & 625 & 20.99 & 2.62 & 0.570 & 31.38 & 8.0 & 16 \\
\hline \multirow{2}{*}{ \#028 after framing } & 625 & 21.06 & 2.61 & 0.566 & 31.14 & 8.0 & 16 \\
\hline & & & & & & & \\
\hline & $0($ Initial) & 21.60 & 2.72 & 0.632 & 37.18 & 9.5 & \\
\hline & 40 & 21.12 & 2.66 & 0.579 & 32.53 & 8.3 & 13 \\
\hline & 202 & 20.99 & 2.63 & 0.575 & 31.71 & 8.1 & 15 \\
\hline & 434 & 21.02 & 2.62 & 0.571 & 31.47 & 8.0 & 15 \\
\hline & 600 & 21.05 & 2.62 & 0.566 & 31.24 & 8.0 & 16 \\
\hline
\end{tabular}


was operating at its peak power point. Table 5 summarizes the light soaking experiment on two modules, Module 27 and Module 28. Module 27 has been degraded 600 hours. Figure 34 is the I-V curve of this module after 600 hours of degradation. The stable module efficiency after 600 hours of one sun light soaking at approximately $50^{\circ} \mathrm{C}$ under load is $8 \%$. In Figure 35 we plot the semilog plot of efficiency to light soaking time. Clearly the module efficiency has come to a saturation under light soaking. We have demonstrated the production of $8 \%$ stable modules. This accomplishes the major first year goal of our PVMaT program. 


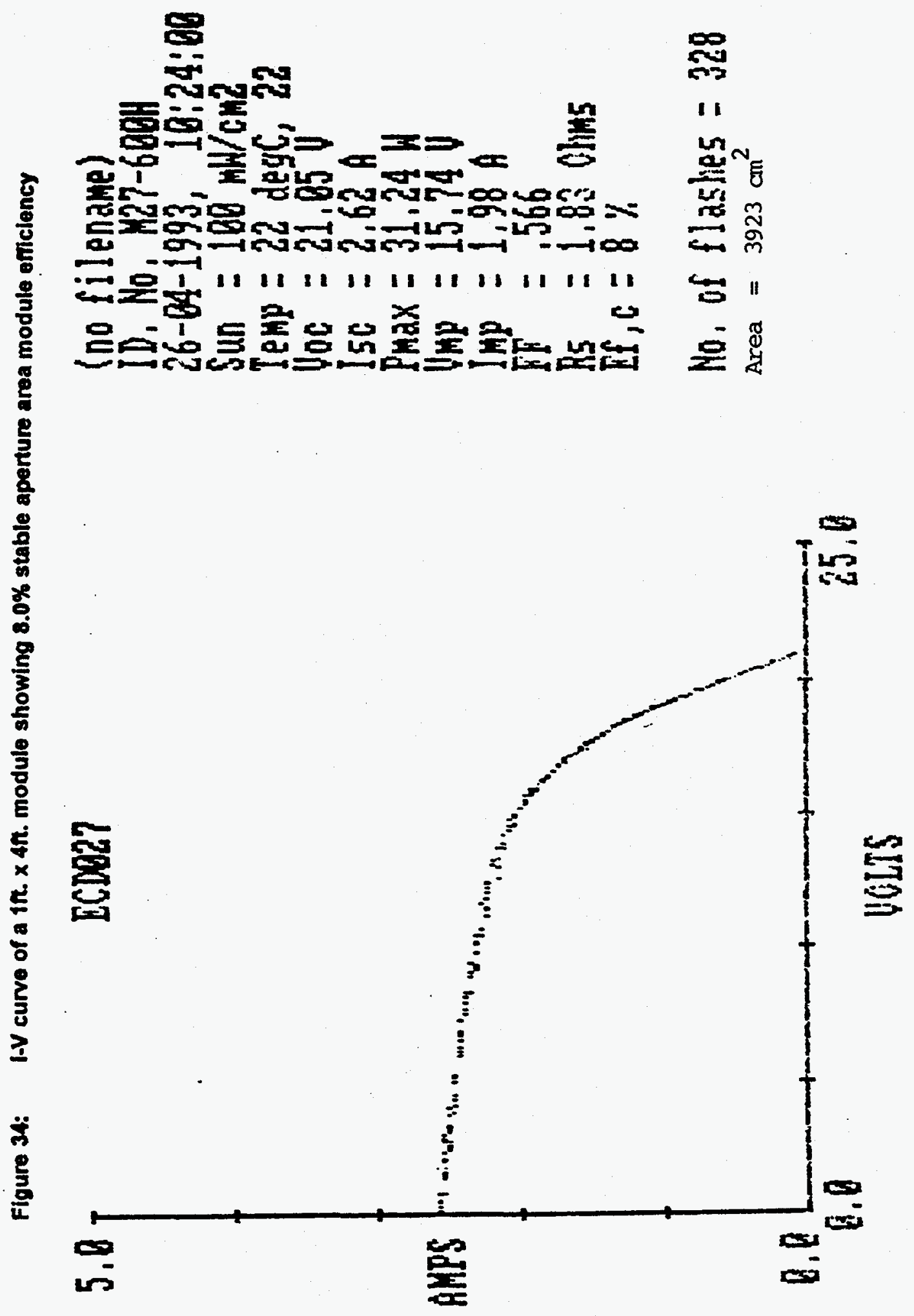


Figure 35: Module efficiencies of two $4 \mathrm{ft}^{2}$ modules as a function of light soaking time under one sun

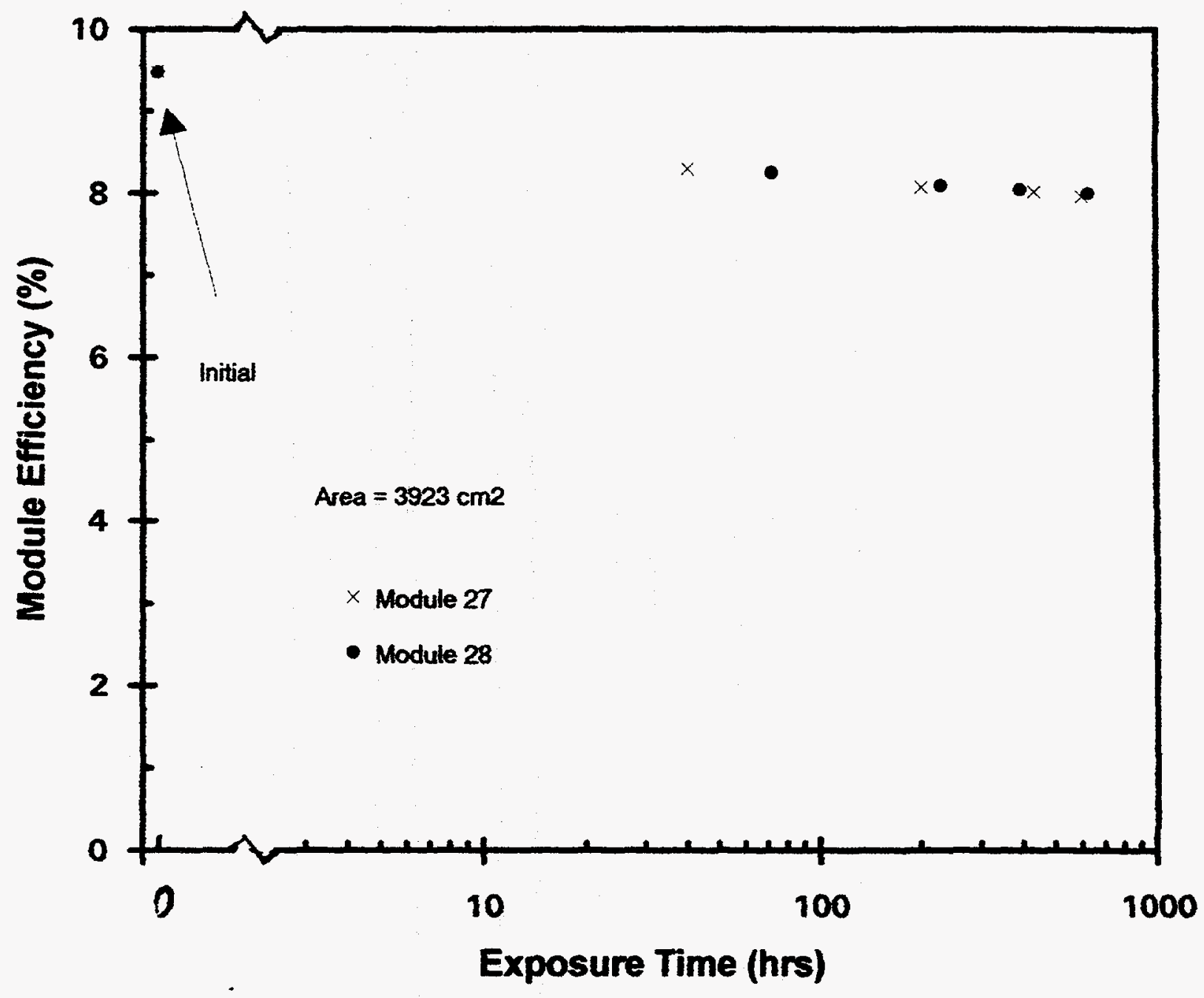




\section{Task 4: Incorporating Microwave Plasma CVD Manufacturing Technology}

In this section, we describe the development of the technology for the generation of large area microwave (MW) excited plasmas used in the high rate deposition of amorphous silicon (a-Si:H) and amorphous silicon/germanium (a-Si-Ge:H) alloys. We first describe the technical challenges confronted in this program. These challenges are both hardware and materials related. Next, the discussion centers on the hardware development. Solving the hardware problems occupied much of the first year of the NREL program. Because of the manufacturing emphasis of this NREL program, it was necessary to modify, and in some cases, to develop entirely new technologies. Finally, the preliminary results on materials and solar cell performance are presented. One issue that is of concern in the high deposition rate of a-Si:H involves porosity, which has been implicated as a possible factor in enhanced light exposure degradation in MW deposited materials compared to RF deposited ones. We have developed a proprietary process directed at increasing the film density and are currently investigating its effectiveness. Preliminary results show that this process can improve the solar cell performance.

\section{Technical Challenges}

There are a number of technical challenges that we have identified. These are both hardware and materials related, and are listed below:

1. Uniform microwave irradiation over scales $\sim 3$ times the wavelength;

2. Transmission of the microwaves into the vacuum deposition chamber while satisfying the above criterion;

3. Minimization of the problems and dangers associated with overcoating of the microwave window by the deposition process. Deposition of a-Si and a-Si-Ge may, under certain plasma illumination and temperature conditions, become conductive enough to absorb the microwave radiation, leading to excessive heating and ultimately to window failure;

4. Compatibility with the continuous ECD deposition process;

5. Suitability of equipment in the production environment. Such concerns include reliability, ease of service, and very importantly safety;

6. Achieving high deposition rates $\sim 100$ angstroms $/ \mathrm{sec}$;

7. Achieving uniformity over large areas. This depends on both the microwave radiation and on the gas flow characteristics; and

8. Achieving stability, at least comparable to RF deposited material.

\section{Development of the Microwave Linear Applicator Technology}

Large scale uniform deposition in RF plasma systems is not a serious issue because the wavelength at $13.56 \mathrm{MHz}$ is more than $22 \mathrm{~m}$, i.e., much greater than any practical deposition chamber! However, since the wavelength at the microwave frequency of 2.45 $\mathrm{GHz}$ is only $12.2 \mathrm{~cm}$, the technical challenges in achieving uniform depositions over the desired scale of $30 \mathrm{~cm}$ are evident. Therefore, deposition results (e.g., film quality from a certain point in parameter space) obtained from small sized microwave research reactors ( $\sim 5 \mathrm{~cm}$ substrates), cannot be automatically applied to the larger production systems. 
Scaling the process to larger sizes is not simply a matter of making larger electrodes (as it is in RF plasma systems) but involves new concepts. Although others have demonstrated high quality a-Si:H films with solar cell efficiencies approaching the best RF deposited material ${ }^{18}$, similar results on the large production scale have yet to be demonstrated.

In spite of these difficulties, substantial progress has been made. The process of creating the hardware was successfully concluded in the third quarter, and work on improving the materials as well as on the solar cell aspects of the program has greatly accelerated since then.

\section{Technological Developments}

We have installed a modified Linear Applicator entirely inside the vacuum environment and using a modified single point MW feed-through as its supply. In this way, the only vacuum MW window is the relatively small MW feed-through itself. Figure 36 shows all the major components of the deposition system. Note that there is no tuning device in the system. In the operation of our system, the average chamber pressure is near $1 \mathrm{mTorr}$. The microwaves travel up the wave guide of the modified Linear Applicator and radiate out the aperture on one side of the guide into a region of slightly higher pressure contained in the Inner Box. A loose fitting quartz plate separates the inside of the guide against the region of elevated pressure. This plate is neither a structural element, nor a major vacuum component. It is therefore not subject to catastrophic failure. The plasma is contained entirely within the Inner Box because it is in here that both the gas and the microwave energy simultaneously flow. In other words, without either a slight enhanced pressure ${ }^{19}$ or the microwaves, no plasma is possible, and so the inside of the Applicator guide remains plasma free. A detailed description of each component is given below, beginning with the modified MW feed-through.

\section{A) Modified MW Feed-Through}

We realized the importance of reducing impedance mismatch through the feed-through. High power measurements showed that for $5 \mathrm{~kW}$ incident from the $\mathrm{MW}$ generator, $2 \mathrm{~kW}$ were reflected by the feed-through so that $3 \mathrm{~kW}$ (at the most) was being delivered into the plasma region. Low power bench top measurements confirmed that $40 \%$ of the incident power was reflected. Those same measurements showed that only about $35 \%$ of the incident power was successfully coupled into the Applicator wave guide. The remaining $25 \%$ contribution was to radiation and/or to resistive losses at the connection between the Applicator wave guide and the feed-through.

From these measurements, it became clear the impedance matching of the three component wave guides (transmission lines) to feed-through to wave guide (Applicator) system was poor. We used destructive interference to eliminate the reflected wave. A schematic of the new MW feed-through is shown in Figure 37(a). It consists of three alumina disks that are each spatially separated by different distances. The middle disk serves as the point to which the vacuum seal is made by a Teflon o-ring.

Low power bench top measurements showed that this new feed-through coupled up to $95 \%$ of the incident energy from the outer wave guide to the Applicator wave guide, with no detectable reflection. High power measurements $(<3 \mathrm{~kW})$ into a dummy load 
Figure 36: Schematic of the deposition chamber showing the MW feed-through and the Linear applicator on the inside of the chamber, along with other major components.

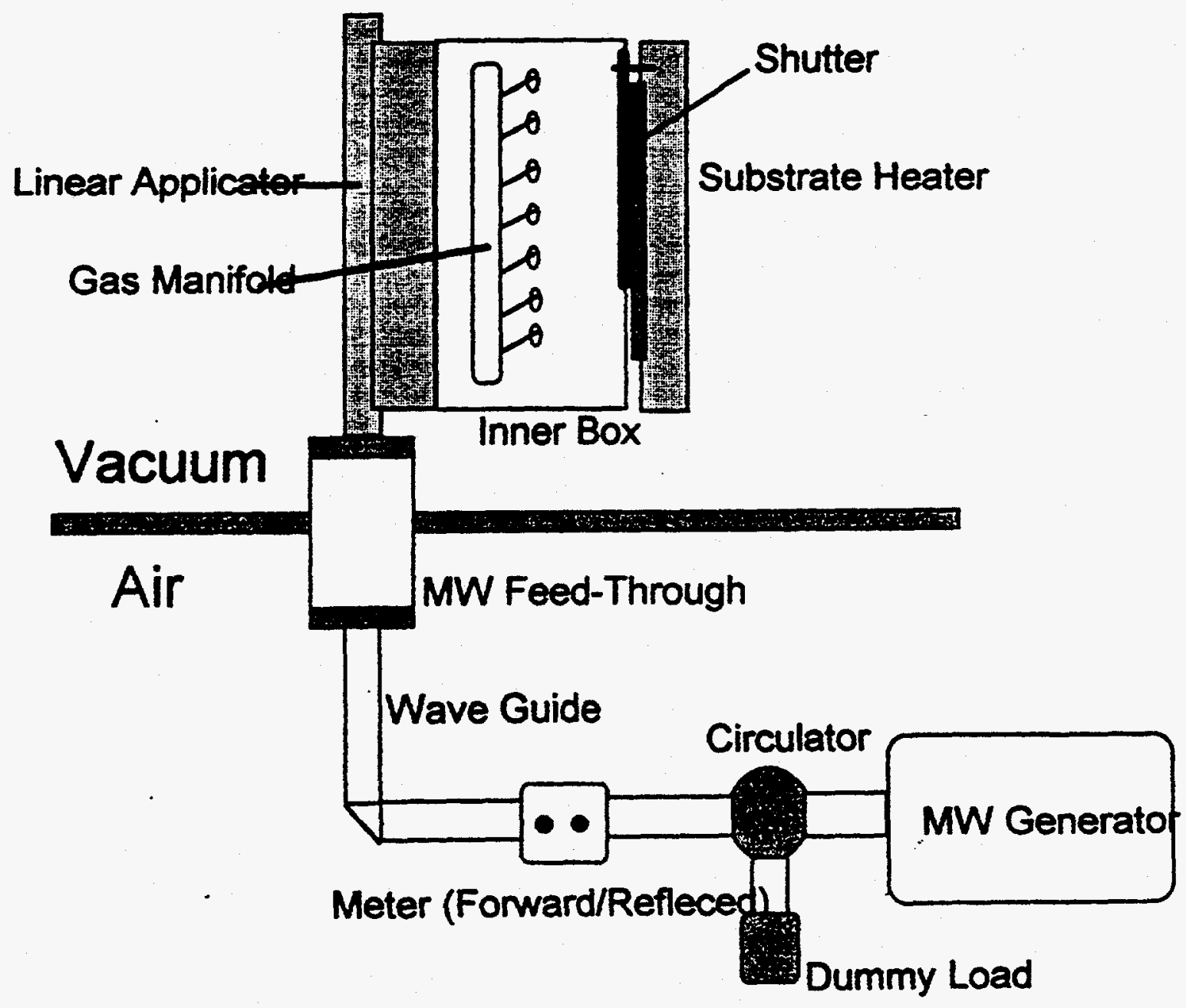




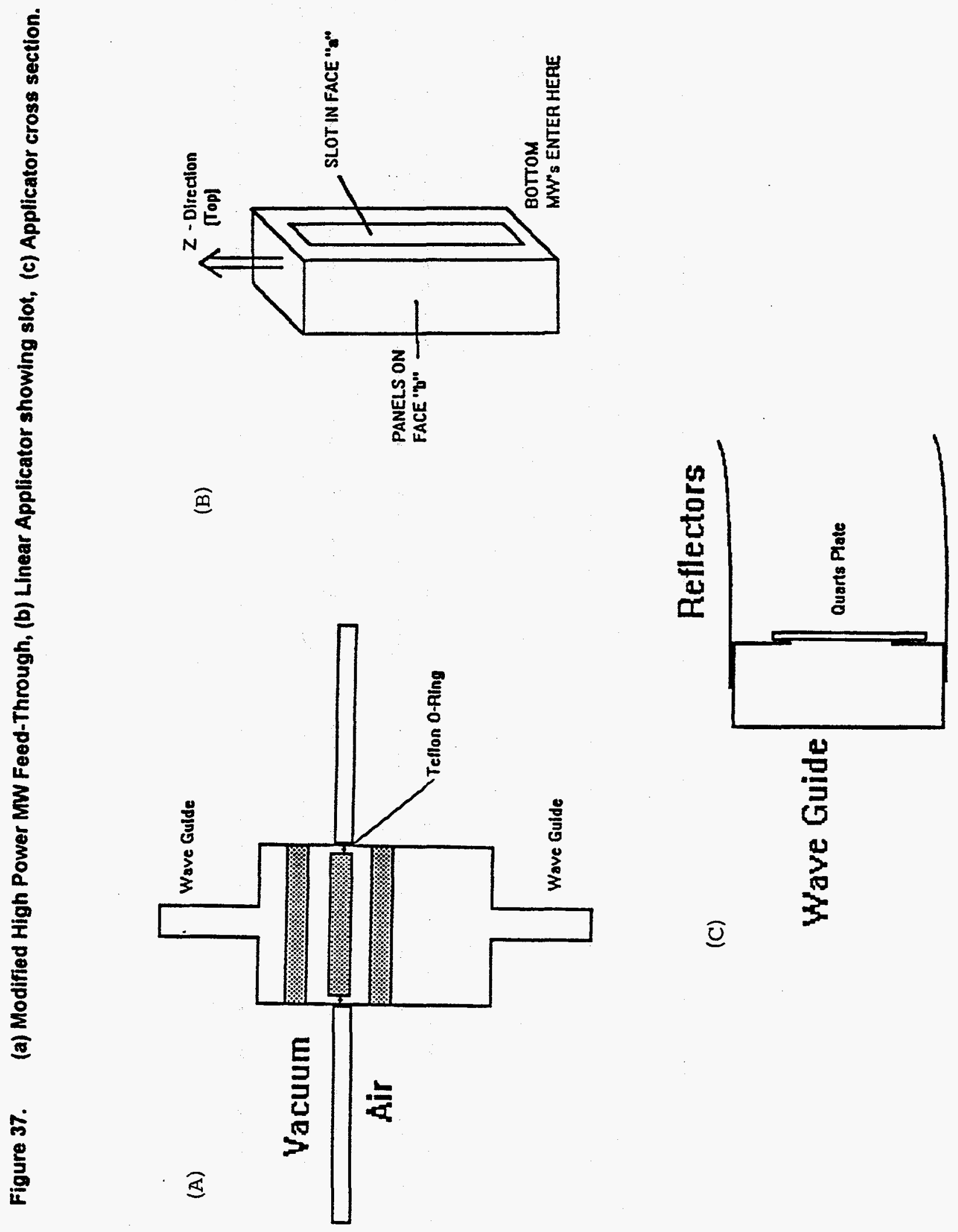


(i.e., no plasma conditions) confirmed the low power results. The unaccounted $5 \%$ is most likely due to resistive losses on the inside of the feed-through. With the nearly perfect transmission, we have achieved a "transparent connection" between the wave guide transmission line and the Applicator wave guide.

With such a high transmission characteristic, much of the $2 \mathrm{~kW}$ (previously reflected) could now be recovered. This meant that a $3 \mathrm{~kW}$ power supply could be used to continue the research on this program. We are currently using $2.4 \mathrm{~kW}$ incident power with about $250 \mathrm{~W}$ reflected under the plasma deposition conditions.

B) Modified Linear Applicator

Our recent work under this NREL program has resulted in the development of a modified feed system for transfering MW power from the source to the plasma chamber. The design provides for the generation of plasma in an extended region.

A schematic of the modified Linear Applicator is shown in Figure 37 (b\&c). The wave guide of the Applicator is standard. A slot is cut along the length of the guide in the $z$ direction on one of the "a" sides. Notice that the width of the slot is uniform along the entire length. Relative to Figures 36 and 37(b), microwaves enter the bottom of the Applicator wave guide from the MW feed-through, and radiate out the slot. Excess MW energy not radiated from the slot is transmitted to the end of the guide (where it also radiates). If the slot is wide enough, and/or the length of the slot is long enough, no energy survives to the end of the guide, and because the slot is of uniform width, the radiation out of the slot decays exponentially from bottom to top.

By the design of an appropriate impedance matching or transformation section, ahead of the slot in the broad wall of the waveguide, reflections at the feed point have been brought down to as low as $5 \%$. Indicating that $95 \%$ of the incoming power can be coupled to the region containing the plasma.

It is clear from the above discussion that uniformity is an inherent feature of this Linear Applicator. If one location along the slot radiates more strongly than neighboring positions, there is then correspondingly more radiation to be reflected and fed back into the wave guide "conduit". This energy can then be redistributed to other locations. With the recent installation of the Inner Box, we have measured a thickness (by capacitance) uniformity of Si-Ge alloy films to be $+1-5 \%$ over $\sim 8$ inches. We believe that gas flow from our gas manifold may be limiting the uniformity.

\section{C) Other Items}

The Modified Linear Applicator described above represents a tuned antenna. This means that the location of the other pieces of hardware, e.g., the substrate, the gas manifold, etc., cannot be positioned arbitrarily. These pieces must be positioned such that as little impact on the radiation pattern as possible is created. We optimized the position of the substrate relative to the reflecting panels, with the nozzles of the gas manifold between the panels and the substrate. 
When the nozzles were very close to the microwave source, plasma tended to form at the exit of each nozzle. The resulting build-up tended to clog the nozzles after a short time (on the order of 30 minutes). It was therefore necessary to relocate the nozzles to a more distant location. This, combined with the need to move the substrate further out, defined the need for a special Inner Box to contain the gas and the microwaves within the same region of space. Also, we have found that after a few hours of total deposition time, the nozzles remain clean. The size and shape of this box, again, was not arbitrarily chosen, but had to satisfy the radiation properties of the Applicator. The point to be made here is that because the $\mathrm{MW}$ wavelength is comparable to most hardware pieces inside the chamber, those pieces can strongly impact the radiation field so the location of those items must be carefully determined.

In summary, we have described a microwave deposition system consisting of a tuned network of MW feed-through, Applicator, Inner Box, and Substrate. Each piece was carefully designed to take advantage of the wave nature of microwaves.

\section{Materials and Solar Cell Characterization}

\section{Amorphous Silicon \& Solar Cells}

Amorphous hydrogenated silicon ( $\mathrm{a}-\mathrm{Si}: \mathrm{H}$ ) was deposited by the $\mathrm{MW}$ system to determine general characteristics of the deposition process. Samples were initially produced with the substrate and gas manifold positioned near to the Linear Applicator. Figure 38 shows the absorption spectra of an a-Si:H sample as determined by photo thermal deflection spectroscopy (PDS). This sample was deposited on 7059 glass at a substrate temperature of $300^{\circ} \mathrm{C}$ and the deposition rate was $54 \mathrm{~A} / \mathrm{sec}$. We find that the integrated absorption yields a defect density of about $1.2 \times 10^{16} \mathrm{~cm}^{-3}$. This is nearly comparable to high quality a-Si:H deposited at rates 10 times less $(<5 \AA / s)$ by the RF plasma deposition process. With defect densities of this low level on glass substrates, we expected to produce high performance solar cells. However, we found that cells made on stainless steel substrates interacted with the microwave plasma and this became an important consideration in the design of the MW deposition system.

The next step that we took was to move the substrate further away from the $M W$ source to reduce the $\mathrm{MW}$ interaction. In so doing, it became necessary to ensure that the reactant gases and the MW energy were confined to the same region of space. It is required to have low pressure inside the Linear Applicator and a relatively higher pressure in the deposition region so that plasma exists only in the deposition zone. The Inner Box was installed to achieve this. Note again, that the shape of the Inner Box must be compatible with the MW radiation characteristics of the system. Also, an added benefit of the Inner Box is that the gas manifold was moved to a more remote region. This prevented plasma from forming on the inside of the nozzles, and thus ensured that the nozzles remain unclogged. Since the chamber is not load-locked, we also installed a substrate shutter (see Figure 36) to minimize effects of chamber contamination.

Solar cell performance is shown in Figure 39. The J-V response under AM1.5 illumination is illustrated in Figure 39(a), and the red and blue response in Figure 39(b), of a single junction cell with $\mathrm{MW}$ deposited intrinsic material. A peak initial efficiency of $6.2 \%$ is obtained. The stainless steel substrate was coated with the back-reflector 
Figure 38: $\quad$ PDS data for MW deposited a-Si:H film.

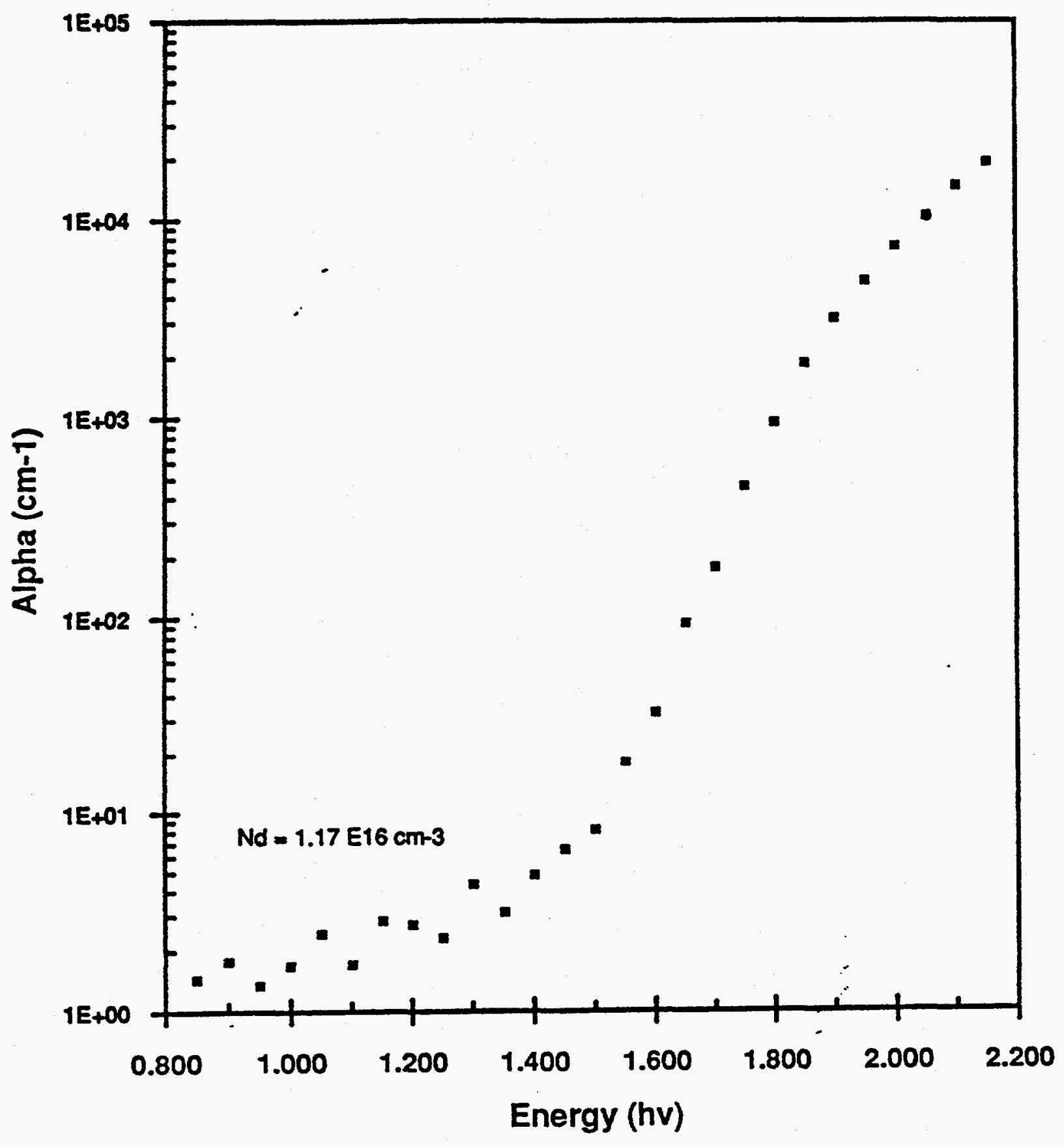


Figure 39. Microwave a-Si:H single junction solar cell J-V curve (a) AM1.5 illumination, (b) Red and Blue response.
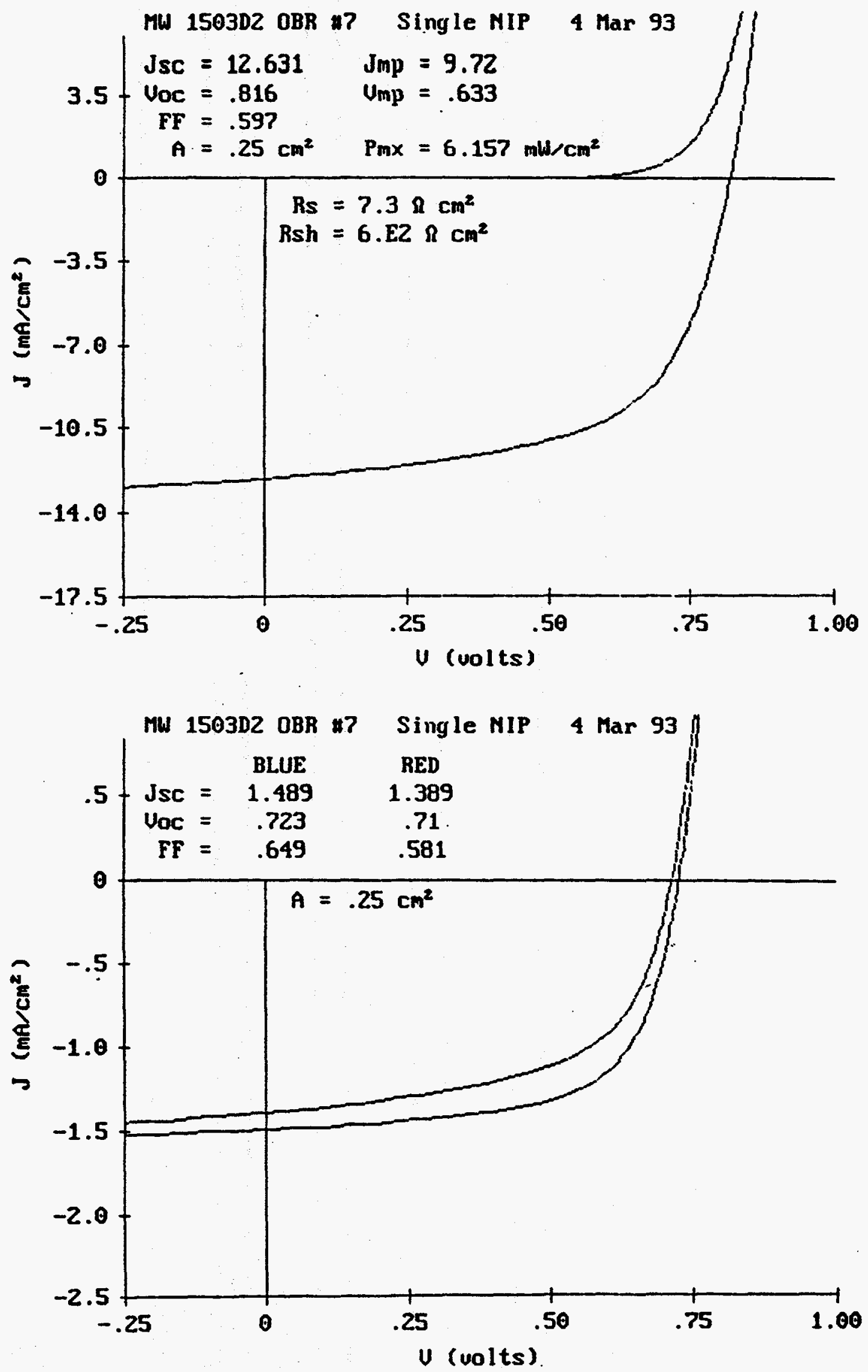
enhancing structure and the n-type layer was first deposited in the "Load Locked" RF plasma deposition system. The sample was then transported (through air) to the MW system to deposit the a-Si:H intrinsic layer, MW(i) layer. Completion of the cell was accomplished by depositing the microcrystalline silicon $\mathrm{p}^{+}$layer in the RF plasma system. The MW(i) layer (2000 $\AA$ ) was deposited at a substrate temperature of $250^{\circ} \mathrm{C}$ using $\mathrm{SiH}_{4}$, $\mathrm{H}_{2}$ and $\mathrm{Ar}$.

\section{Amorphous Silicon Germanium Alloys \& Tandem Solar Cells:}

To deposit the a-Si-Ge alloy films by the microwave (MW) plasma enhanced CVD, we use silane $\left(\mathrm{SiH}_{4}\right)$ and germane $\left(\mathrm{GeH}_{4}\right)$ reactant gases for the source of silicon and germanium in the deposited films. This is different from our standard RF plasma process, in which disilane $\left(\mathrm{Si}_{2} \mathrm{H}_{6}\right)$ is used rather than silane as the silicon source because the decomposition rate of disilane is greater than that of silane. The more comparable decomposition rates of disilane and germane, afford greater control of the film's alloy composition. However, our work with MW deposited a-Si:H has shown that its deposition rate is supply limited, i.e., limited by the flow rate of the silicon source, silane $\left(\mathrm{SiH}_{4}\right)$. Moreover, a comparison of the deposition rate and the silane flow rate indicates that the gas utilization is on the order of unity. Because of the high efficiency in which silane is decomposed in microwave plasmas, we might expect that its decomposition rate be comparable to germane's, so that the $\mathrm{Si}_{\mathrm{x}} \mathrm{Ge}_{1-\mathrm{x}}$ alloy stoichiometry of the film should simply be related to the relative gas flow of germane to silane. The results are shown in Figure 40. The film's composition for each gas flow mixture was determined by Energy Dispersive Spectroscopy (EDS). The fact that the slope of the line is very near to 1.0 verifies the above contention that the incorporation efficiency of silicon (as derived from silane) to be identical with the incorporation efficiency of germanium (from germane).

The Tauc energy gap for a $23 \%$ Ge alloy film, deposited at 22 Angstroms/sec by the MW process, was measured by optical transmission spectroscopy and found to be $1.6 \mathrm{eV}$. This is well within the range of energies (1.55 eV to $1.65 \mathrm{eV}$ ) found for RF deposited material at this germanium content ${ }^{20}$.

Incorporating the a-Si-Ge alloy material into the double junction tandem solar cells has begun in the last quarter. Figure 41 shows the J-V curve of such a solar cell showing a peak power output of $7.23 \mathrm{~mW} / \mathrm{cm}^{2}$ under AM1.5 illumination. The bottom a-Si-Ge alloy layer was deposited in the MW deposition system, while the other layers of the device were deposited in the "Load Locked" RF plasma deposition system. The substrate was stainless steel with a back reflector structure consisted of texturized silver and $\mathrm{ZnO}$. The bottom $\mathrm{n}$ type layer was first deposited in the RF plasma system, and then the sample was transferred (through atmosphere) to the MW deposition system. Approximately 1700 angstroms of intrinsic a-Si-Ge alloy material, MW (i), was then deposited. The sample was then transferred back to the RF plasma system to be completed. Note that "buffer" layers were not used, either before or after the deposition of the MW (i) layer. The top RF(i) a-Si:H layer was 1000 angstroms thick. 
Figure 40: Si:Ge Alloy composition vs. gas composition.

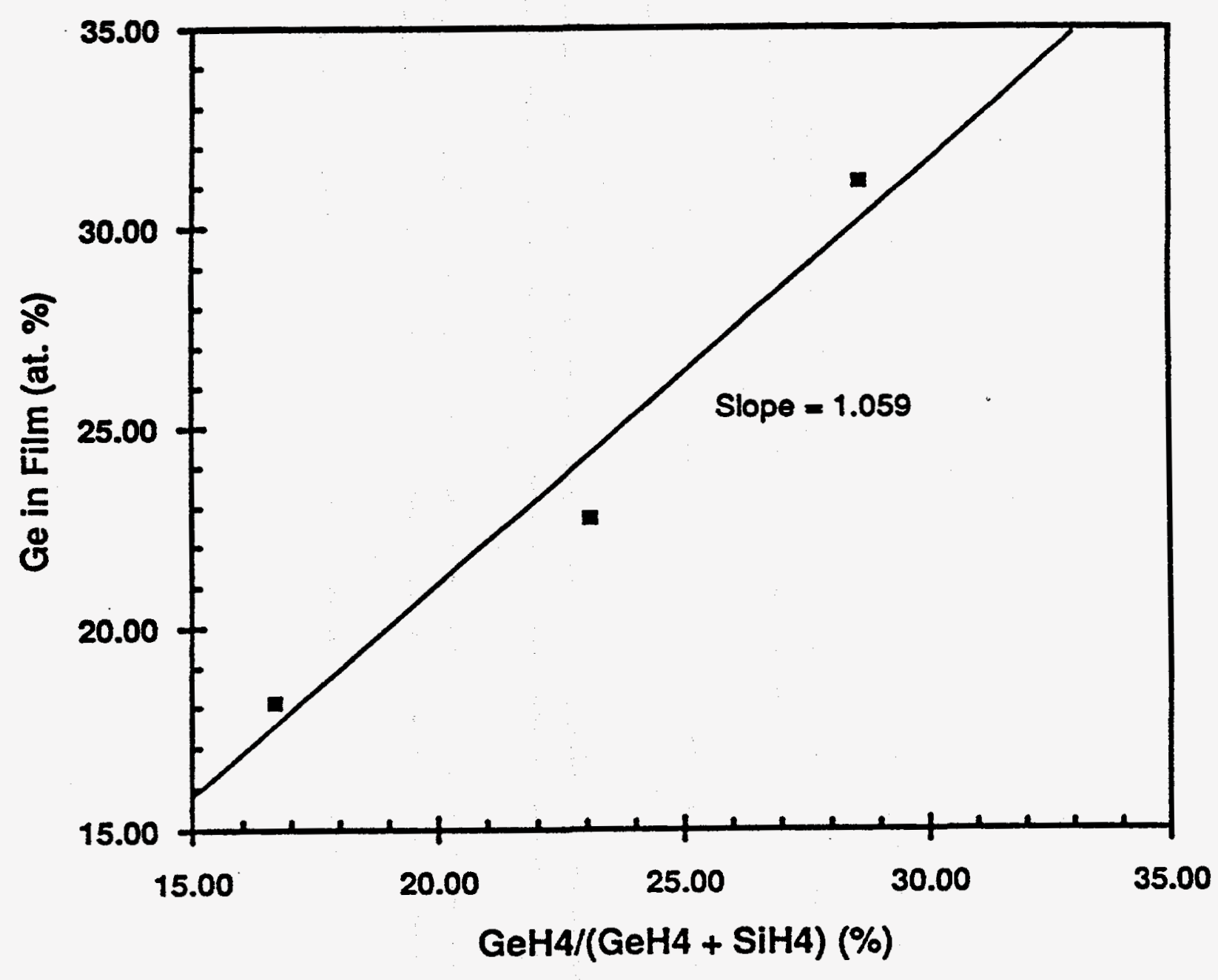




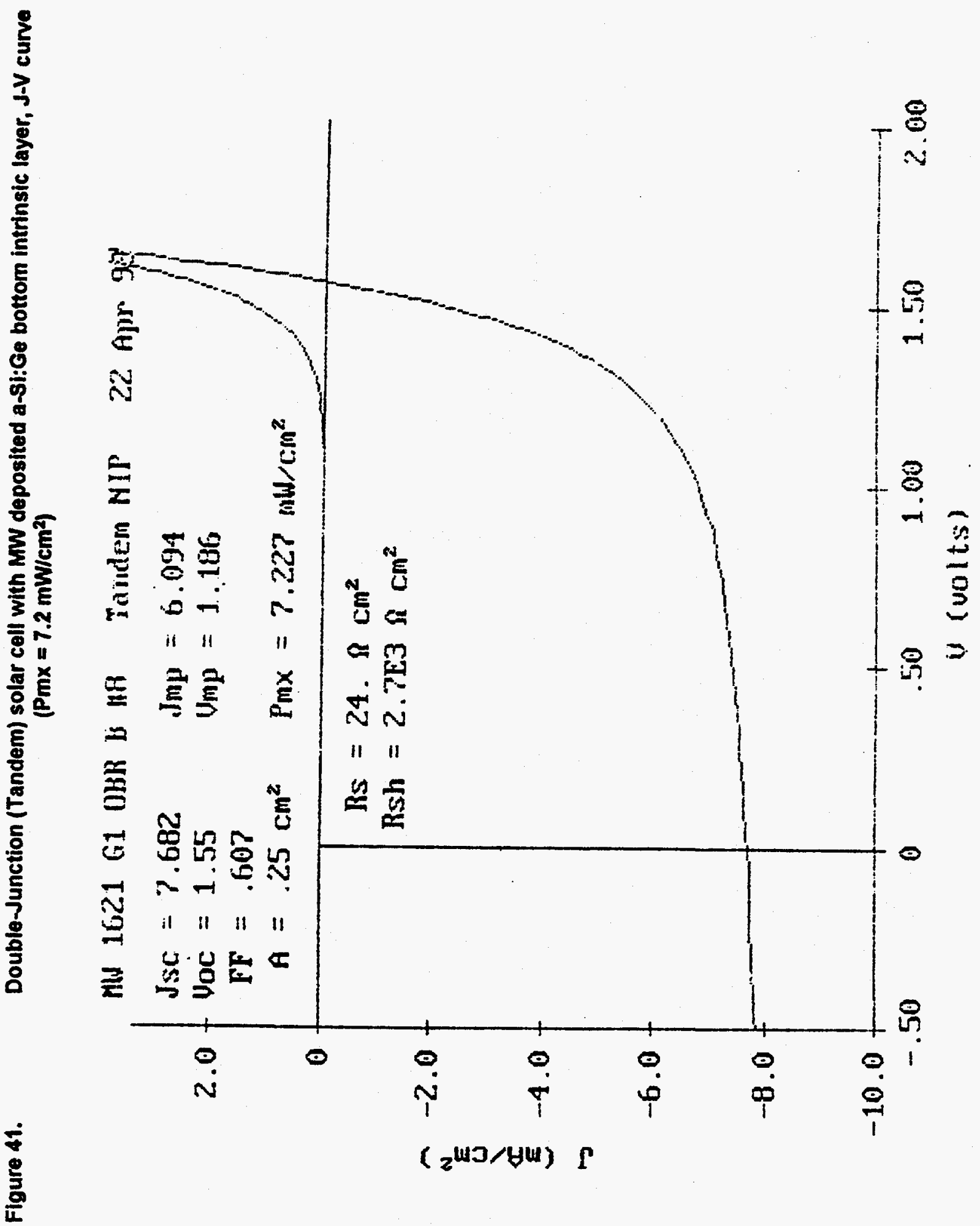




\section{TASK 5: MATERIAL COST REDUCTION}

Under Task 5, we focused our efforts in two major high material cost areas;

1) reduction of germane and disilane costs

2) reduction of module assembly material costs

One of the highest cost items in the bills of materials for ECD's triple-junction multiple band-gap a-Si alloy solar cell consisting of $\mathrm{Si} / \mathrm{Si} / \mathrm{Si}-\mathrm{Ge}$ structure is germane and disilane. In this program period, efforts were made to determine long term price projections for these gases. We have identified Mitsui Toatsu and Voltaic as the world's largest manufacturers for disilane and germane gases, respectively. Germane and disilane gases used in this program were supplied by these companies. The prices were substantially lower than the current world prices due to contracted large volume purchase. We also worked with our Russian joint venture partner, Sovlux, to achieve cost reductions for these gases. We have obtained disilane and germane gases produced in Russia. The results of purity analyses of these gases indicated that germane had acceptable purity, whereas disilane had unacceptable high levels of impurities. Currently, the Russian supplier is constructing a germane production line and improving the purity of disilane.

The material cost for these gases have been substantially reduced over our original estimated costs due to;

1) the thickness reduction of the Si-Ge narrow band-gap solar cells

2) the increased gas utilization factor as the result of optimization of solar cell structure and deposition conditions

We have achieved $77 \%$ cost reduction for germane and $58 \%$ for disilane in our continuous roll-toroll process compared to our original estimate based upon earlier experiments done in a large-area $\left(1 \mathrm{ft}^{2}\right)$ batch deposition machine. Table 6 summarizes the cost reduction for gases.

A new, low-cost module design to reduce assembly material cost has been developed. The new design, shown in Figure 42, utilizes a marine plywood panel to eliminate the aluminum frame and steel backing plate. The resulted cost reduction will be approximately $30 \%$, as is summarized in Table 7.

The marine plywood module has been tested for 50 thermal cycles and 20 humidity/freeze cycles. The module did not show any power loss and passed front surface Hi-pot test. However, the module failed fully submerged Hi-pot test due to a crack in the patting compound to the junction box. A new junction box has been engineered to correct the problem.

As a result of the Task 5 program described above, we have achieved material cost reduction from $\$ 2.81 / \mathrm{W}$ for the original technology to $\$ 1.51 / \mathrm{W}$ for the improved technology. 
Table 6: Cost-reduction summary for Germane and disilane gases

Original Estimated Material*

Requirement
Optimized Material

Requirement

Under Task $5^{\text {** }}$
Cost

Reduction

GERMANE

0.61

0.14

$77 \%$

DISILANE

0.47

0.20

* Based upon experiments done in a large-area $\left(1 \mathrm{ft}^{2}\right)$ batch deposition machine.

* Improvements were due to improved gas utilization and thickness reduction. 


\section{Figure 42: Low-cost marine plywood module}
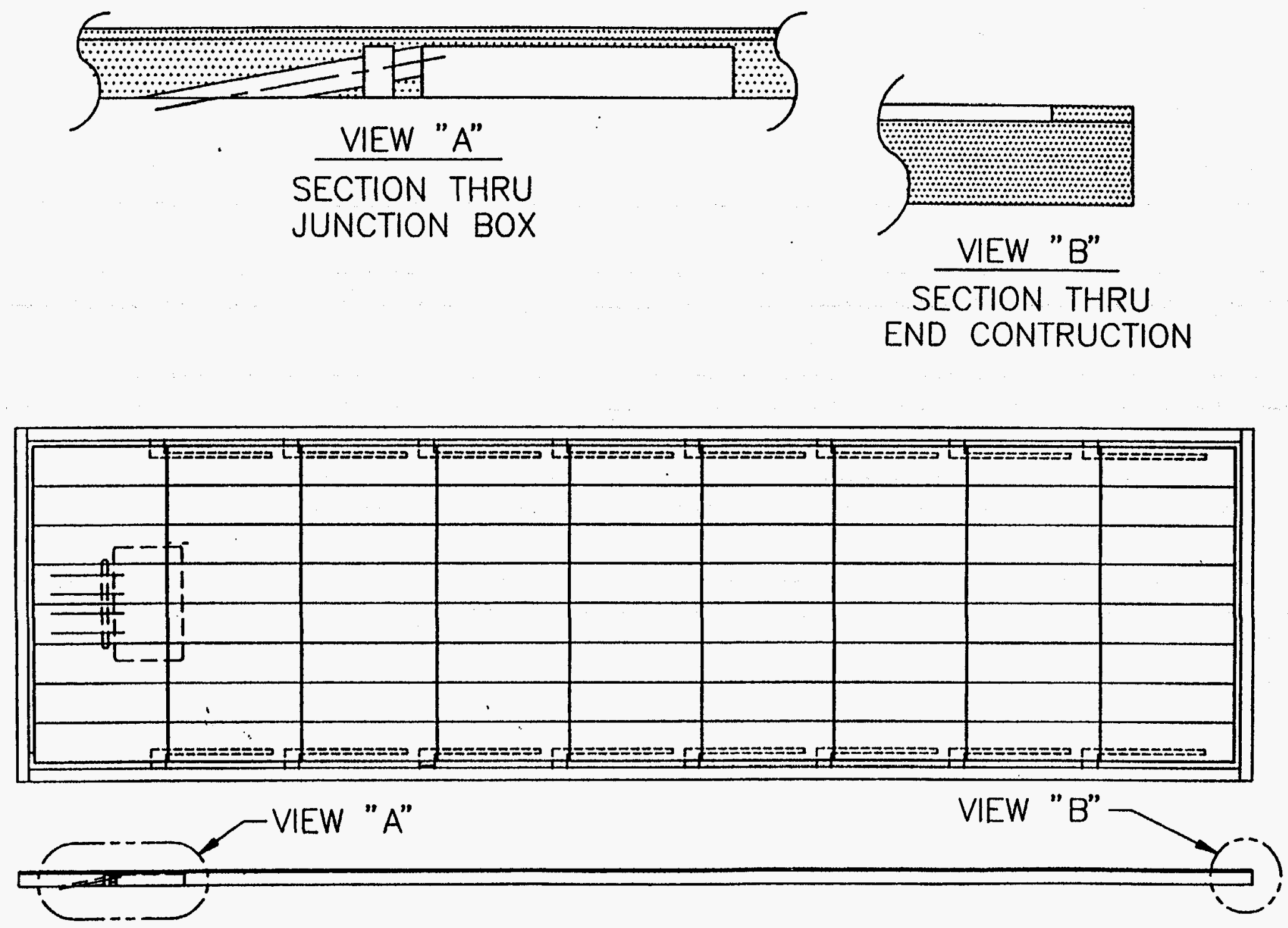
Table 7:

Summary of assembly material cost reduction for the low-cost marine plywood module

Operation

Screening

Strip Assembly

Interconnection

Lamination

Finishing

Total
Al frame $1 \mathrm{ft} . \times 4 \mathrm{ft}$. module

2.01

3.44

2.48

17.60

12.19

37.71
Marine Plywood

Module

2.01

3.44

1.62

17.19

2.15

26.41
Reduction

$0 \%$

$0 \%$

$34.7 \%$

$2.3 \%$

$82.4 \%$

$30.0 \%$ 


\section{References}

1 Production of Tandem Amorphous silicon Alloy Cells in a Continuous Roll-to-Roll Process, M. Izu and S. R. Ovshinsky, SPIE Proc. 407, 42 (1983).

2 Roll-to-Roll Plasma Deposition Machine for the Production of Tandem Amorphous Silicon Alloy Solar Cells, M. Izu and S. R. Ovshinsky, Thin Solid Films 11955 (1984).

3 Amorphous Silicon Solar Cells Production in a Roll-to-Roll Plasma CVD Process, H. Morimoto and M. Izu, JARECT 16 (1984); Amorphous Semiconductor Technology \& Devices, North Holland Publishing Company, Edited by Y. Hamakawa, 212 (1984).

4 Roll-to-Roll Mass Production Process for Amorphous Silicon Solar Cell Fabrication, S. R. Ovshinsky, Proc. International PVSEC-1, 577 (1984).

$5 \quad$ High Efficiency Multiple-Junction Solar Cells Using Amorphous Silicon and Amorphous Silicon-Germanium Alloys, J. Yang, R. Ross, T. Glatfelter, R. Mohr, G. Hammond, C. Bernotaitis, E. Chen, J. Burdick, M. Hopson and S. Guha, Proc. 20th IEEE P.V. Spec. Conf. 241 (1988).

6 Physics of High Efficiency Multiple-Junction Solar Cells, J. Yang, R. Ross, R. Mohr and J. P. Fournier, Proc. MRS Symp. Vol. 95, 517 (1987).

7 Performance of Large Area Amorphous Silicon Based Single and Multiple-Junction Solar Cells, P. Nath and M. Izu, Proc. of the 18th IEEE Photovoltaic Specialists Conf., Las Vegas, Nevada, 939 (1985).

8 IMW Amorphous Silicon Thin-Film PV Manufacturing Plant, P. Nath, K. Hoffman, J. Call, C. Vogeli, M. Izu and S. R. Ovshinsky, Proc. of the 3rd International Photovoltaic Science and Engineering Conf., Tokyo, Japan, 395 (1987).

9 Conversion Process for Passivation Current Shunting Paths in Amorphous Silicon Alloy Solar Cells, P. Nath, K. Hoffman, C. Vogeli and S. R. Ovshinsky, Appl. Phys. Lett. 53 (11), 986 (1988).

10 Yield and Performance of Amorphous Silicon Based Solar Cells Using Roll-to-Roll Deposition, P. Nath, K. Hoffman, J. Call, G. Didio, C. Vogeli and S. R. Ovshinsky, Proc. 20th IEEE P.V. Spec. Conf., 293 (1988).

11 A New Inexpensive Thin Film Power Module, P. Nath, K. Hoffman, C. Vogeli, K. Whelan and S. R. Ovshinsky, Proc. 20th IEEE P.V. Spec. Conf., 1315 (1988).

12 Fabrication and Performance of Amorphous Silicon Based Tandem Photovoltaic Devices and Modules, P. Nath, K. Hoffman and S. R. Ovshinsky, 4th International P.V. Science and Engineering Conf., Sydney, Australia, (1989). 
13 Advances in High-Efficiency, Multiple-Band-Gap, Multiple-Junction Amorphous Silicon Based Alloy Thin-Film Solar Cells, S. Guha, A Paper Presented at MRS Spring Meeting, San Diego, April (1989).

14 Amorphous Silicon-Germanium Alloy Solar Cells with Profiled Band-Gaps, J. Yang, R. Ross, T. Glatfelter, R. Mohr and S. Guha, MRS Symposium Proc. Vol. 149, 435 (1989).

15 Low-Pressure Microwave PECVD Technology, M. Izu, S. J. Hudgens, J. Doehler and B. Dotter, Proc. 4th International Conf. on Vacuum Web Coating, 129 (1990).

16 High Deposition Rate Amorphous Silicon Alloy Xerographic Photoreceptor, S. J. Hudgens and A. J. Johncock, Proc. MRS Symp. Vol. 49, 403 (1985).

17 Amorphous Semiconductors for Microelectronics, S. J. Hudgens, Proc. SPIE Vol. 617, 95 (1986).

18 S. Guha, J. Yang, Private communication, USSC, Troy, MI

19 Jes Asmussen, "Electron cyclotron resonance microwave discharge for etching and thinfilm deposition," J. Vac. Sic. Technol. A7 (3), 883 (1989)

20 Werner Luft, "Characteristics of hydrogenated amorphous silicon-germanium alloys," Appl. Phys. Comm. 9 (1 \& 2), 43 (1989) 


\begin{tabular}{|c|c|c|c|}
\hline $\begin{array}{c}\text { Document Control } \\
\text { Page }\end{array}$ & $\begin{array}{l}\text { 1. NREL Report No. } \\
\text { NREL/TP-411-6003 }\end{array}$ & $\begin{array}{l}\text { 2. NTIS Accession No. } \\
\text { DE } 94000260\end{array}$ & 3. Recipient's Accession No. \\
\hline \multirow{2}{*}{\multicolumn{3}{|c|}{$\begin{array}{l}\text { 4. Title and Subtitle } \\
\text { Continuous Roll-to-Roll a-Si Photovoltaic Manufacturing Technology }\end{array}$}} & $\begin{array}{l}\text { 5. Publication Date } \\
\text { December } 1993 \\
\end{array}$ \\
\hline & & & 6. \\
\hline \multicolumn{3}{|l|}{$\begin{array}{l}\text { 7. Author(s) } \\
\text { M. Izu }\end{array}$} & 8. Performing Organization Rept. No. \\
\hline \multirow{2}{*}{\multicolumn{3}{|c|}{$\begin{array}{l}\text { 9. Performing Organization Name and Address } \\
\text { Energy Conversion Devices, Inc. } \\
1675 \text { West Maple Road } \\
\text { Troy, Michigan } 48084\end{array}$}} & $\begin{array}{l}\text { 10. Project/TaskWork Unit No. } \\
\text { PV450101 }\end{array}$ \\
\hline & & & $\begin{array}{l}\text { 11. Cöntract (C) or Grant (G) No. } \\
\text { (C) ZM-2-11040-7 } \\
\text { (G) }\end{array}$ \\
\hline \multirow{2}{*}{\multicolumn{3}{|c|}{$\begin{array}{l}\text { 12. Sponsoring Organization Name and Address } \\
\text { National Renewable Energy Laboratory } \\
1617 \text { Cole Blvd. } \\
\text { Golden, CO } 80401-3393\end{array}$}} & $\begin{array}{l}\text { 13. Type of Report \& Period Covered } \\
\text { Technical Report } \\
1 \text { April } 1992 \text { - } 31 \text { March, } 1993\end{array}$ \\
\hline & & & 14. \\
\hline \multicolumn{4}{|c|}{$\begin{array}{l}\text { 15. Supplementary Notes } \\
\text { NREL technical monitor: R. Mitchell }\end{array}$} \\
\hline \multicolumn{4}{|c|}{$\begin{array}{l}\text { 16. Abstract (Limit: } 200 \text { words) } \\
\text { This report describes work done under a } 3 \text {-year program to advance ECD's roll-to-roll, triple-junction photovoltaic } \\
\text { manufacturing technologies, to reduce the module production costs, to increase the stabilized module performance, and to } \\
\text { expand commercial capacity utilizing ECD technology. The specific } 3 \text {-year goal is to develop advanced large-scale } \\
\text { manufacturing technology incorporating ECD's earlier research advances with the capability of producing modules with stable } \\
11 \% \text { efficiency at a cost of approximately } \$ 1.00 \text { per peak watt. Accomplishments during Phase } 1 \text { included: (1) ECD } \\
\text { successfully incorporated a high-performance Ag/metal-oxide back-reflector system into its continuous roll-to-roll commercial } \\
\text { production operation. (2) High-quality a-Si-Ge narrow-band-gap solar cells were incorporated into the manufacturing. } \\
\text { (3) ECD demonstrated the continuous roll-to-roll production of high-efficiency, triple-junction, two-band-gap solar cells } \\
\text { consistently and uniformly throughout a } 762-\mathrm{m} \text { (2500-ft) run with high yield. (4) ECD achieved } 11.1 \% \text { initial sub-cell } \\
\text { efficiency of triple-junction, two-band-gap a-Si alloy solar cells in the production line. (5) The world's first } 0.37-\mathrm{m}^{2}\left(4-\mathrm{ft}^{2}\right) \\
\text { PV modules were produced utilizing triple-junction spectrum-splitting solar cells manufactured in the production line. (6) As } \\
\text { a result of process optimization to reduce the layer thickness and to improve the gas utilization, ECD achieved a } 77 \% \text { material } \\
\text { cost reduction for germane and } 58 \% \text { reduction for disilane. Additionally, ECD developed a new low-cost module that saves } \\
\text { approximately } 30 \% \text { in assembly material costs. }\end{array}$} \\
\hline \multicolumn{4}{|c|}{$\begin{array}{l}\text { 17. Document Analysis } \\
\text { a. Descriptors } \\
\text { amorphous silicon ; manufacturing ; photovoltaics ; solar cells }\end{array}$} \\
\hline \multirow{2}{*}{\multicolumn{2}{|c|}{$\begin{array}{l}\text { 18. Availability Statement } \\
\text { National Technical Information Service } \\
\text { U.S. Department of Commerce } \\
5285 \text { Port Royal Road } \\
\text { Springfield, VA } 22161\end{array}$}} & & $\begin{array}{l}\text { 19. No. of Pages } \\
84\end{array}$ \\
\hline & & & $\begin{array}{r}\text { 20. Price } \\
\text { A05 }\end{array}$ \\
\hline
\end{tabular}

